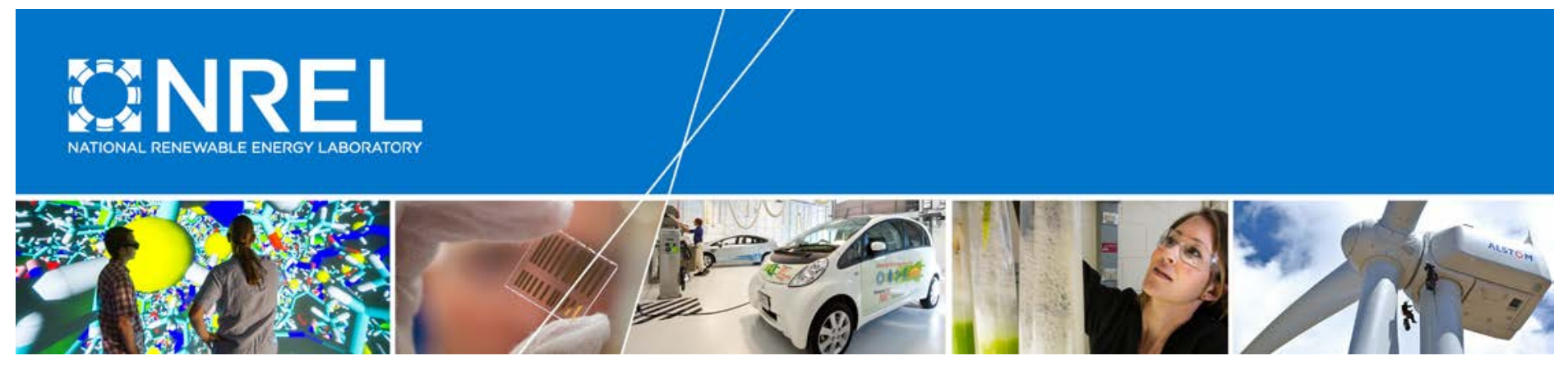

\title{
Initial Investigation into the Potential of CSP Industrial Process Heat for the Southwest United States
}

Parthiv Kurup and Craig Turchi National Renewable Energy Laboratory

NREL is a national laboratory of the U.S. Department of Energy Office of Energy Efficiency \& Renewable Energy Operated by the Alliance for Sustainable Energy, LLC

This report is available at no cost from the National Renewable Energy Laboratory (NREL) at www.nrel.gov/publications.

Technical Report

NREL/TP-6A20-64709

November 2015 


\section{Initial Investigation into the Potential of CSP Industrial Process Heat for the Southwest United States}

Parthiv Kurup and Craig Turchi National Renewable Energy Laboratory

Prepared under Task Nos. CP13.3510 and ST6C.0410
NREL is a national laboratory of the U.S. Department of Energy Office of Energy Efficiency \& Renewable Energy Operated by the Alliance for Sustainable Energy, LLC

This report is available at no cost from the National Renewable Energy Laboratory (NREL) at www.nrel.gov/publications.

\section{Technical Report}

NREL/TP-6A20-64709

November 2015

Contract No. DE-AC36-08GO28308
National Renewable Energy Laboratory 15013 Denver West Parkway 303-275-3000 • www.nrel.gov 


\title{
NOTICE
}

This report was prepared as an account of work sponsored by an agency of the United States government. Neither the United States government nor any agency thereof, nor any of their employees, makes any warranty, express or implied, or assumes any legal liability or responsibility for the accuracy, completeness, or usefulness of any information, apparatus, product, or process disclosed, or represents that its use would not infringe privately owned rights. Reference herein to any specific commercial product, process, or service by trade name, trademark, manufacturer, or otherwise does not necessarily constitute or imply its endorsement, recommendation, or favoring by the United States government or any agency thereof. The views and opinions of authors expressed herein do not necessarily state or reflect those of the United States government or any agency thereof.

This report is available at no cost from the National Renewable Energy Laboratory (NREL) at www.nrel.gov/publications.

Available electronically at SciTech Connect http:/www.osti.gov/scitech

Available for a processing fee to U.S. Department of Energy and its contractors, in paper, from:

\author{
U.S. Department of Energy \\ Office of Scientific and Technical Information \\ P.O. Box 62 \\ Oak Ridge, TN 37831-0062 \\ OSTI http://www.osti.gov \\ Phone: 865.576.8401 \\ Fax: 865.576.5728 \\ Email: reports@osti.gov
}

Available for sale to the public, in paper, from:

\author{
U.S. Department of Commerce \\ National Technical Information Service \\ 5301 Shawnee Road \\ Alexandria, VA 22312 \\ NTIS http://www.ntis.gov \\ Phone: 800.553 .6847 or 703.605 .6000 \\ Fax: 703.605.6900 \\ Email: orders@ntis.gov
}




\section{Acknowledgments}

This work was supported by the U.S. Department of Energy under Contract No. DE-AC36-08GO28308 with the National Renewable Energy Laboratory. Funding was provided by the Office of Energy Efficiency and Renewable Energy Solar Energy Technologies Program. 


\section{Executive Summary}

After significant interest in the 1970s, but relatively few deployments, the use of solar technologies for thermal applications, including enhanced oil recovery (EOR), desalination, and industrial process heat (IPH), is again receiving global interest. In particular, the European Union (EU) has been a leader in the use, development, deployment, and tracking of Solar Industrial Process Heat (SIPH) plants.

The objective of this study is to ascertain U.S. market potential of IPH for concentrating collector technologies that have been developed and promoted through the U.S. Department of Energy's Concentrating Solar Power (CSP) Program. For this study, the solar-thermal collector technologies of interest are parabolic trough collectors (PTCs) and linear Fresnel (LF) systems.

This report first reviews global SIPH activities that employ concentrating collector technologies. From that basis it explores the potential of SIPH, with emphasis on the state of California. The best entry markets for SIPH in the United States are the regions having excellent Direct Normal Irradiance (DNI) resource and IPH-user industries. The opportunity for deployment of SIPH is identified by understanding and breaking down the industrial use of direct process heat and steam in the U.S. market into submarkets. The report also maps industries requiring IPH with locations having suitable DNI for solar-thermal facilities.

Regarding industrial use of direct process heat and steam, this report focuses on the southwestern states, and in particular, California. The assessment for California indicates a technical thermal energy potential (i.e., the achievable solar energy generation given collector performance, topographic limitations, environmental and land-use constraints) of almost 23,000 $\mathrm{TWh}_{\mathrm{th}} / \mathrm{yr}_{\text {. }}$ This dwarfs the estimated demand of about $48 \mathrm{TWh}_{\mathrm{th}} / \mathrm{yr}$ for the five industrial sectors in California that utilize the most natural gas for IPH. It is important to highlight, the proximity of the solar supply/potential and the demand at site is more important for SIPH than solar generation of electricity.

An assessment of suitable SIPH applications must consider the temperature capabilities of the solar collectors as well as the temperature requirements of the target markets. This study identified three general regions of temperatures between $80^{\circ} \mathrm{C}$ and $400^{\circ} \mathrm{C}$ that can be defined for linear concentrating collectors based mainly on the most suitable heat transfer fluid (HTF). The low-temperature region of $80-200^{\circ} \mathrm{C}$ is best suited for use of water or steam, the intermediate region of $200-300^{\circ} \mathrm{C}$ can utilize direct steam generation (DSG) or mineral oils, and the hightemperature region of $300-400^{\circ} \mathrm{C}$ must use DSG or more costly synthetic oils. It is further noted that the industrial demand for steam is dominated by temperatures in the range of 120 to $220^{\circ} \mathrm{C}$. Thus, the best SIPH market target is believed to be systems using pressurized water or steam in the range of 120 to $220^{\circ} \mathrm{C}$. Because this temperature is well below the level employed at electricity-generating CSP plants, there may be advantages to optimizing collector/receiver and thermal energy storage designs for this temperature regime.

The cost for solar-generated heat by SIPH is quantified by defining the levelized cost of heat $(\mathrm{LCOH})$ in a fashion analogous to the familiar levelized cost of energy (LCOE). California offers a favorable environment for SIPH given its good insolation, gas prices typically higher than the national average, and policies promoting solar-thermal deployment. Prior efforts to promote 
widespread SIPH development in the 1970s and 1980s failed because heat from solar fields could not compete with natural gas prices. Given historically low gas prices, this remains a challenge today. However, solar field costs have fallen dramatically in the past decade and this study finds that the solar LCOH for many regions in California is lower than the LCOH from natural gas, using a representative installed solar hardware price and the average price for industrial natural gas in California. Economics of individual cases will be governed by the project-specific attributes, such as contract gas price, access to land, and process flexibility.

Based on global experience, the food sector is viewed as a good candidate for early adoption of SIPH systems. For example, one of the largest SIPH plants in the world uses solar heat to fry potato chips in Modesto, California. In addition to the economic potential described above, this sector may recognize a marketing benefit in the use of solar energy that helps offset the risk of deploying the technology.

The present study highlights the potential of SIPH in California; this could lead to consideration and eventual deployment of new SIPH facilities. Such deployment would expand use of solarthermal collectors, helping to drive down the cost of the hardware and leveraging the investment made by DOE's Solar Energy Technologies Office. IPH represents about $29 \%$ of all primary energy used in the manufacturing sector, which is the thermal energy equivalent of 5,700 CSP plants the size of Nevada Solar One. Expansion of solar energy into this market is expected to help reduce U.S. carbon dioxide emissions associated with fossil fuel combustion. 


\section{Table of Contents}

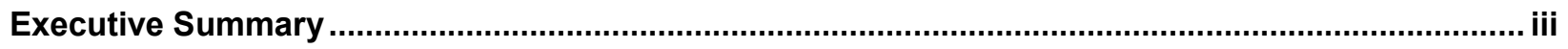

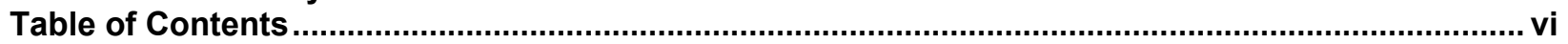

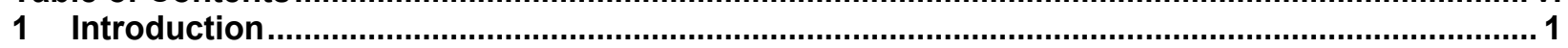

1.1 How Solar Thermal can Meet the Needs of IPH ...................................................................... 2

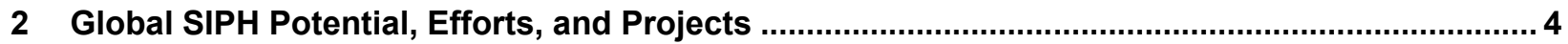

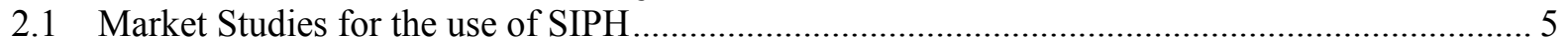

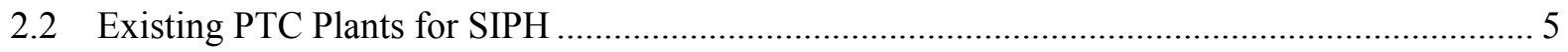

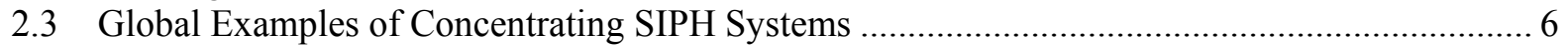

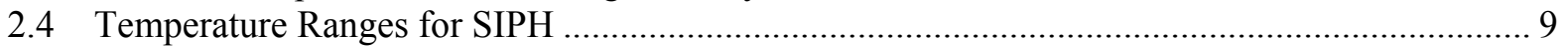

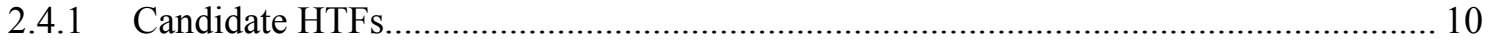

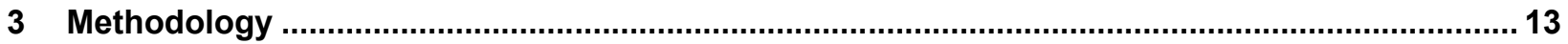

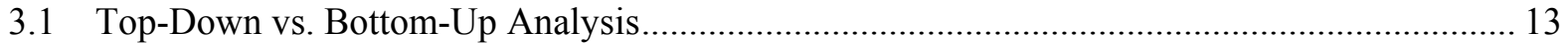

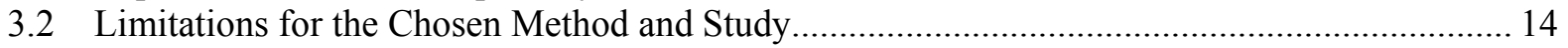

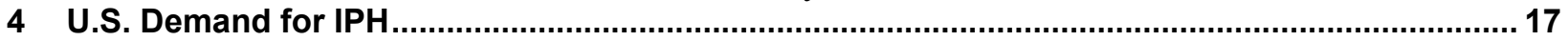

4.1 U.S. Industrial Consumption of Natural Gas for Process Heat ............................................... 20

4.2 California Industrial Natural Gas Consumption.................................................................. 23

4.3 Natural Gas Prices for Industry Across the U.S. Southwest ................................................... 25

4.4 Southwestern U.S. DNI and Solar-Thermal Energy Potential ................................................ 26

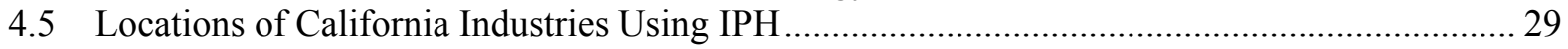

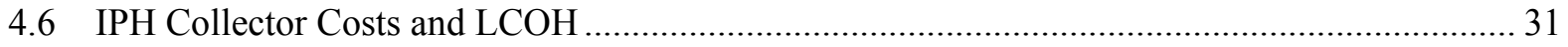

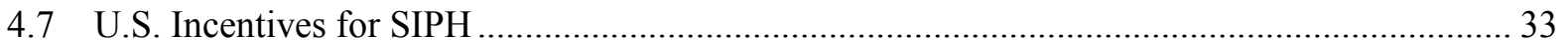

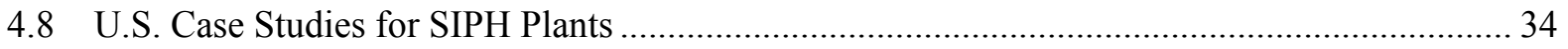

4.8.1 Modesto Frito Lay Food Processing Plant ..................................................................... 34

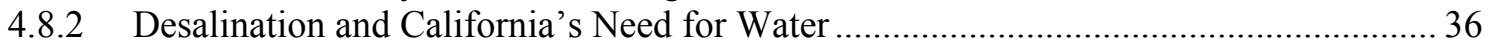

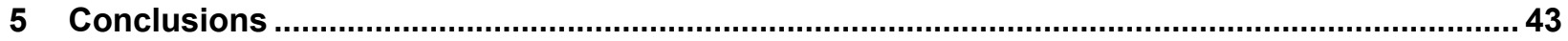

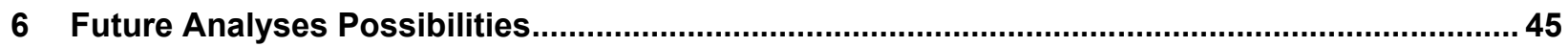

Appendix A. Industry Sectors with Potential for SIPH Application ................................................47

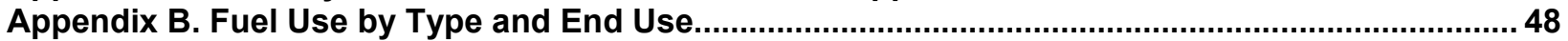

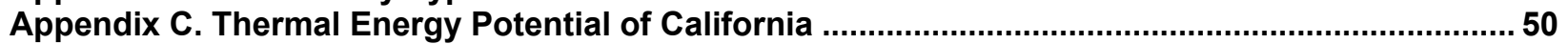

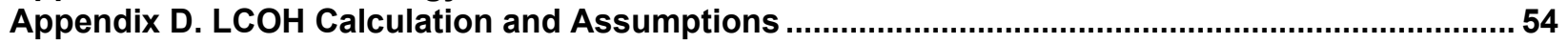

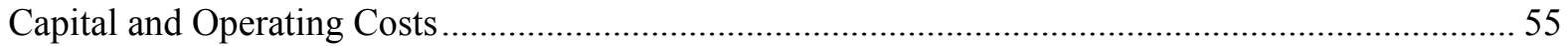

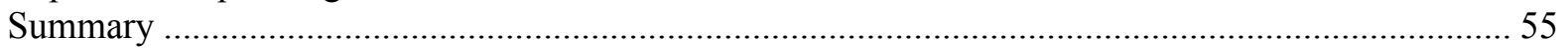

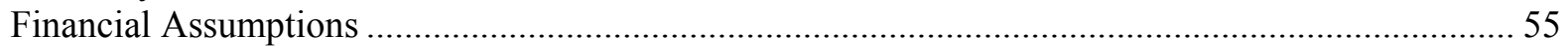

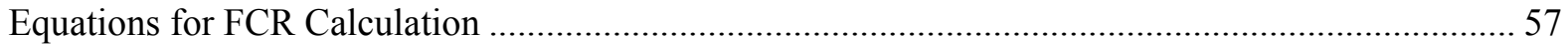

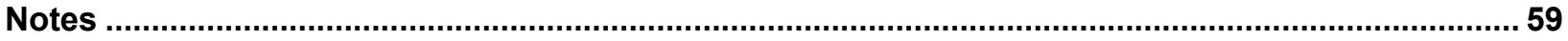

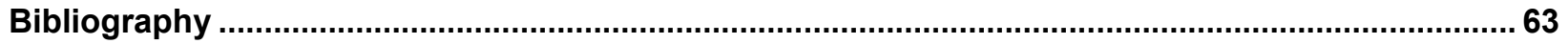




\section{List of Figures}

Figure 1. Estimated temperature range for solar energy heat technologies ............................................. 3

Figure 2. Solar IPH plants built across the world from 1980 to 2015 (left chart) and in the United States

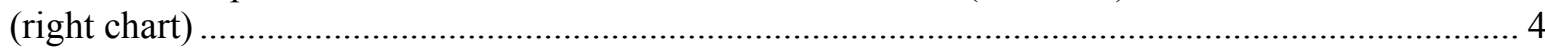

Figure 3. Cumulative number and kWth capacity of PTC IPH plants worldwide as of June 2015 ............ 6

Figure 4. PTC IPH plants across the world by industry served (as of May 2015).................................. 6

Figure 5. CSP PTCs used for generating heat at the Cremo SA milk processing centre ........................... 7

Figure 6. TSE1 site in Thailand where the Solarlite SL 4600s were being utilized for DSG.................... 7

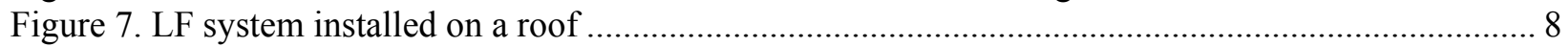

Figure 8. Methodology developed for this study to determine U.S. SIPH potential with an example of the

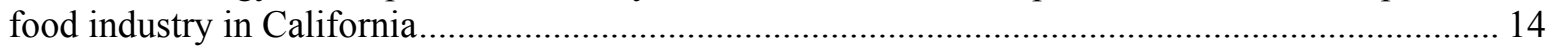

Figure 9. Sankey diagram of the annual primary energy flow in the U.S. manufacturing sector.............. 17

Figure 10. Sankey Diagram of annual process energy flow in U.S. manufacturing sector. Process energy

is a subset of primary energy (see Figure 9) ............................................................................. 18

Figure 11. MECS 2010 energy end use by percentage and quantity (TBtu/yr) ...................................... 19

Figure 12. Energy consumption within the MECS industries by end-use category as of $2010 \ldots \ldots \ldots \ldots \ldots \ldots . . .19$

Figure 13. Total U.S. consumption of natural gas (NG) by MECS sector and natural gas used for direct

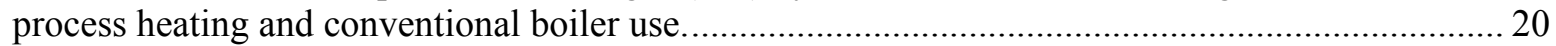

Figure 14. IPH annual energy use for steam generation for the industries utilizing the greatest amount of

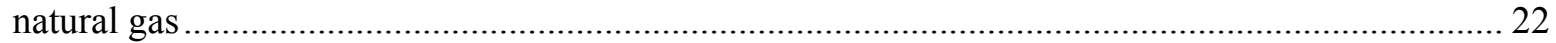

Figure 15. Industrial natural gas end use for California as of 2005 ...................................................... 23

Figure 16. Industrial electrical end use for California as of 2005 ...................................................... 24

Figure 17. Natural gas prices for industry for the southwestern United States (2009 to 2014) ................ 25

Figure 18. U.S. annual average DNI map (data from 1998 to 2009) .................................................... 26

Figure 19. Solar-thermal energy potential $(\mathrm{MWhth} / \mathrm{km} 2)$ for California based on DNI and land area

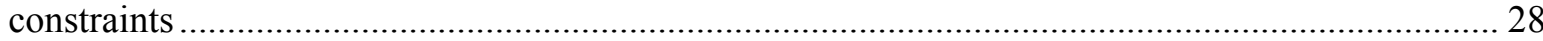

Figure 20. Locations of animal-food processing, breweries, and dairy products plants across California along with annual solar-thermal energy potential

Figure 21. Close up of Fresno showing the solar-thermal generation potential and potential user industries30

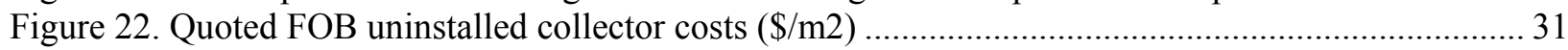

Figure 23. Estimated installed collector costs per $\mathrm{m} 2$ for a 20 -ha SIPH installation................................ 32

Figure 24. Estimated LCOH for different solar resource and solar field costs compared with two LCOHs from the use of natural gas at U.S. and Californian Industrial natural gas prices ........................... 33

Figure 25. Modesto and Panoche SIPH plants as of Sept. 2014 ........................................................... 34

Figure 26. PTCs at the Frito Lay Modesto food processing plant ....................................................... 35

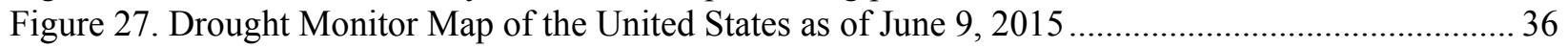

Figure 28. Western U.S. drought maps comparing June 9, 2015 and June 10, 2015 ............................ 37

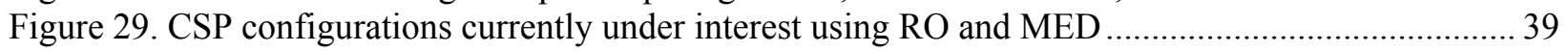

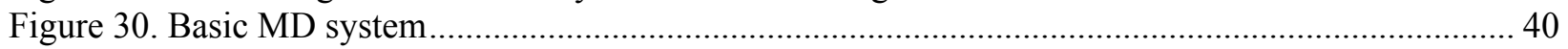

Figure 31. Solar thermal-gradient pond paired with a MED thermal desalination system ....................... 41

Figure 32. SkyTrough CSP collector at the Panoche desalination pilot plant ........................................ 41

Figure 33. 2010 MECS overall natural gas breakdown by end use ..................................................... 49

Figure 34. 2010 MECS overall electricity end use breakdown ...................................................... 49

Figure 35. Solar technical thermal energy potential of CA overlaid on animal-food processing sites....... 51

Figure 36. Solar technical thermal energy potential of CA overlaid on the breweries ............................. 52

Figure 37. Solar technical thermal energy potential of CA overlaid on locations of dairy product

manufacturers. 


\section{List of Tables}

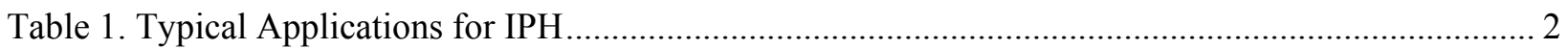

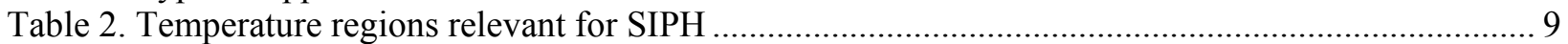

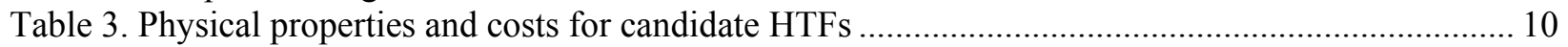

Table 4 Temperature-dependent properties for candidate HTFs. ...................................................... 11

Table 5. Safety/environmental characteristics of candidate heat-transfer fluids based on U.S. National Fire

Protection Association (NFPA) ratings. NFPA rankings range from no risk (0) to high risk (4)..... 12

Table 6. List of Specific Industries Included in the MECS (NAICS Codes 31-33) ................................ 15

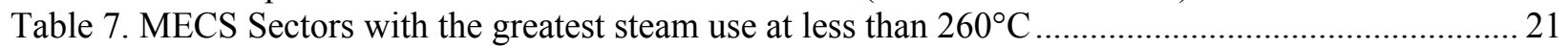

Table 8. U.S. natural gas consumption for direct process heating and conventional boiler use in high-use

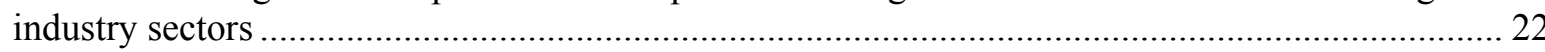

Table 9. Natural gas consumption (TBtu/yr) for California by use sector (as of 2013) .......................... 23

Table 10. Estimated natural gas consumption for direct process heating and boiler use in California for

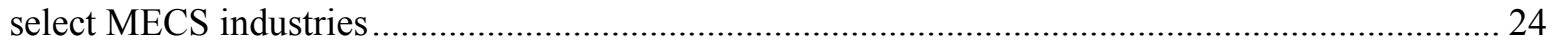

Table 11. Thermal Power Density and Capacity Factor by DNI Class...................................................2 28

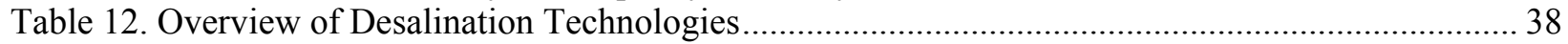

Table 13. Studies globally regarding industries that could be suitable for SIPH applications .................. 47

Table B-1. End use fuel consumption for all MECS 2010 industries in the United States....................... 48

Table C-1. Annual technical thermal energy potential by county in California ....................................... 50

Table D-1. LCOH calculation method patterned after the fixed charge rate LCOE calculation in SAM 2015-06-30. Calculated values are defined in the text below........................................................ 54 


\section{Nomenclature}

$\begin{array}{ll}\text { AHP } & \text { Absorption heat pump } \\ \text { LF } & \text { Linear Fresnel } \\ \text { CSP } & \text { Concentrating solar power } \\ \text { DOE } & \text { Department of Energy } \\ \text { DNI } & \text { Direct normal irradiance } \\ \text { DSG } & \text { Direct steam generation } \\ \text { EIA } & \text { Energy Information Agency } \\ \text { EU } & \text { European Union } \\ \text { FCR } & \text { Fixed charge rate } \\ \text { HTF } & \text { Heat transfer fluid } \\ \text { IEA } & \text { International Energy Agency } \\ \text { IPH } & \text { Industrial process heat } \\ \text { GIS } & \text { Geographic information system } \\ \text { LCOE } & \text { Levelized cost of energy (electricity) } \\ \text { LCOH } & \text { Levelized cost of heat } \\ \text { LF } & \text { Linear Fresnel (collector) } \\ \text { MECS } & \text { Manufacturing Energy Consumption Survey } \\ \text { MED } & \text { Multi-effect distillation } \\ \text { MGD } & \text { Million gallons per day } \\ \text { MSF } & \text { Multi-stage flash } \\ \text { NAICS } & \text { North American Industry Classification System } \\ \text { NREL } & \text { National Renewable Energy Laboratory } \\ \text { OECD } & \text { Organization for Economic Cooperation and Development } \\ \text { PTC } & \text { Parabolic trough collector } \\ \text { RO } & \text { Reverse osmosis } \\ \text { SAM } & \text { System Advisor Model } \\ \text { SHC } & \text { Solar heating and cooling } \\ \text { SHIP } & \text { Solar heat for industrial processes } \\ \text { SIPH } & \text { Solar industrial process heat } \\ \text { TBtu } & \text { Trillion British thermal units } \\ { }^{1} \text { Fox, Sutter, and Tester, “The Thermal Spectrum of Low-Temperature Energy Use in the United States.” } \\ \end{array}$




\section{Introduction}

Thermal energy and steam are ubiquitous needs in industrial processes. From the extraction of raw materials to food processing, heat is a vital part of the processing and manufacturing sectors. In the last several years, interest in using solar thermal collectors to generate the heat needed for industrial processes and applications has grown. Concentrating Solar Power (CSP) plants for electricity production have seen great expansion in the past decade, with large plants constructed in the Europe Union (EU), Africa, Australia, and the United States. These concentrating technologies can achieve relatively high temperatures - for example, linear-focus collectors can reach temperatures up to about $500^{\circ} \mathrm{C}$, and point-focus technologies can go to even higher temperatures. For solar hardware developers, expansion into industrial process heat (IPH) offers access to new markets for CSP collector technologies. Greater market size, in turn, can drive down the cost of CSP collectors through economies of scale in manufacturing and learning-curve advances in deployment. This report looks at the potential for CSP collector technologies applied to IPH in the United States. The study focuses on California and the states of the southwest.

In the 1970s and 1980s there was a great deal of interest in collection of solar thermal energy for buildings and process heat applications ${ }^{2,3}$. Despite significant effort, very few projects came to fruition, mainly due to solar collector cost relative to the alternative price of natural gas ${ }^{4}$. In recent years, the improvement and proliferation of solar collectors for electricity generation and the development of sophisticated solar collector modeling tools has regenerated interest in solar process heat applications. In 1977, the International Energy Agency (IEA) established the Solar Heating and Cooling (SHC) program and looked to create an environment for the development and progression of SHC. ${ }^{5}$ An EU-led collaborative project between the IEA SHC and the SolarPACES program, known as Task 49/Task IV, was set up specifically to address establishing and helping to meet the potential of solar for IPH. ${ }^{6}$ Much of the initial work dealt with the potential of non-concentrating, flat-plate collectors. Flat-plate solar collectors are common in many countries, including the United States, where the overwhelming majority is applied for domestic home heating or heating water for pools. ${ }^{7}$ While these are excellent applications for low-temperature collectors, this report deals with the growing interest in the deployment of concentrating collector technologies that can achieve temperatures needed within the industrial sector.

The EU in the last decade has been leading the research into $\mathrm{SIPH}^{\mathrm{a}}$, and increasing plant installations are indicative of the increasing interest. However, as of 2015, despite great potential, the worldwide adoption of CSP technologies for IPH generation is modest. Due to the excellent solar resource conditions in the United States (especially in the Southwest) and the ubiquitous need for IPH, the United States provides a sizeable opportunity for greater deployment of solar-thermal collectors with the associated benefits of increased solar jobs, lower carbon emissions, and potential cost reductions in collector technologies. For example, within the U.S. industrial sector, the estimated consumption of energy for heat for applications such as washing, sterilization, and preheating was approximately $24,000 \mathrm{TBtu}$ in $2014 .{ }^{8 \mathrm{~b}}$

\footnotetext{
a Note that the IEA uses the acronym SHIP for "solar heat for industrial processes." This report will refer to these applications as solar industrial process heat, or SIPH.

${ }^{\mathrm{b}} 1$ trillion Btu (TBtu) is approximately equal to $10^{15} \mathrm{~J}$ or $293 \mathrm{GWh}_{\mathrm{th}}$
} 
This report will show that for California in particular, the solar technical potential to supply heat from CSP can theoretically meet California's demand for heat in major industries that use IPH.

The next section of this report covers a brief introduction into IPH and how concentrating solarthermal technologies can provide energy to this application. Section 2 highlights global SIPH projects and efforts. Section 3 addresses the methodology used for this study. Section 4 provides results of understanding the potential thermal energy demand within selected industries and then the thermal energy potential in California for SIPH. Conclusions and recommendations follow.

\subsection{How Solar Thermal can Meet the Needs of IPH}

Industrial and manufacturing companies have a large appetite for thermal energy. Research has found the majority of process heat demand stems from either direct heating or steam generation, where steam is typically generated indirectly in a fossil-fuel boiler. ${ }^{9}$ One study in Germany found $74 \%$ of the entire industrial energy consumption $\left(641 \mathrm{TWh}_{\mathrm{th}} / \mathrm{yr}\right)$ was utilized to meet thermal demand for areas such as process heat, space heating, and water heating. ${ }^{10}$ Table 1 shows a sample of typical processes and applications (under $400^{\circ} \mathrm{C}$ ) that use process heat either through direct heating or indirect heating and steam generation. As can be seen, there are numerous applications where heat (conventionally produced through electricity or fossil fuel) is utilized for IPH applications.

Table 1. Typical Applications for IPH ${ }^{11}$

\begin{tabular}{|l|l|l|l|l|l|}
\hline $\begin{array}{l}\text { Fluid } \\
\text { Heating }\end{array}$ & Calcining & Drying & Heat Treating & $\begin{array}{l}\text { Metal and Non- } \\
\text { Metal Heating }\end{array}$ & $\begin{array}{l}\text { Curing and } \\
\text { Forming }\end{array}$ \\
\hline Air heating & Cement & Crude oil & Aging & Cleaning & $\begin{array}{l}\text { Resin and } \\
\text { plastics }\end{array}$ \\
\hline $\begin{array}{l}\text { Liquid } \\
\text { Heating }\end{array}$ & $\begin{array}{l}\text { Coke } \\
\text { calcining }\end{array}$ & $\begin{array}{l}\text { Food and by } \\
\text { products }\end{array}$ & Coating & Glass heating & Heat forming \\
\hline Reforming & $\begin{array}{l}\text { Minerals } \\
\text { calcining }\end{array}$ & $\begin{array}{l}\text { Pulp and } \\
\text { paper }\end{array}$ & Homogenizing & & $\begin{array}{l}\text { Paint and } \\
\text { organic coating }\end{array}$ \\
\hline
\end{tabular}

The recent growth in CSP has been focused on the construction of large electric-generating plants. In these facilities, solar energy is first concentrated and used to heat a heat transfer fluid (HTF). The HTF may be water/steam, oil, or molten salt. Generated steam can be expanded directly into a turbine to produce electricity. Non-steam HTFs are used to produce steam in a dedicated steam boiler prior to the steam turbine. Linear-focus CSP technologies such as parabolic trough collectors (PTCs) and linear Fresnel (LFs) are ideally suited for producing hot $\mathrm{HTF}$ or steam at temperatures up to about $500^{\circ} \mathrm{C}$. Figure 1 illustrates temperature ranges where the main solar thermal collector technologies can supply heat or steam. As can be seen, concentrating collectors (i.e., PTCs and LFs) can easily supply heat in the range required for common industrial needs. ${ }^{12}$ It is worth highlighting that the SIPH plant needs to be collocated or near to the industrial plant be supply the heat input for the industrial processes, as heat or steam transmission is limited in comparison to electricity generation. 


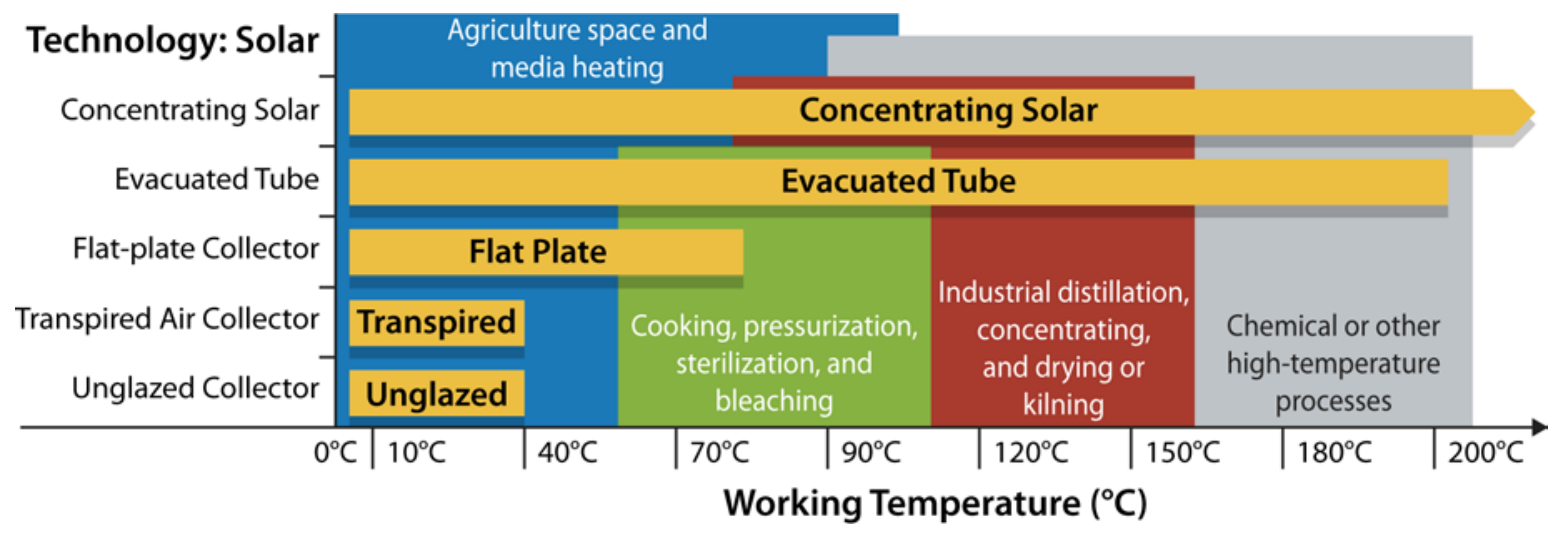

Figure 1. Estimated temperature range for solar energy heat technologies ${ }^{13}$

The objective of this study is to ascertain market potential within IPH for collector technologies that have been developed and promoted through the DOE CSP Program. As will be shown, the majority of IPH needs fall within a range of temperature that is most suited for linear-focus collector technologies such as PTCs and LFs. The DOE CSP Program has long supported the development of linear-collector technologies, and that research assisted the development and deployment of CSP plants such as Nevada Solar One (Nevada), Martin Next Generation Solar Energy Center (Florida), Genesis (California), Solana (Arizona), and Sundt Solar Booster (Arizona), among others. Low-temperature heating in the range of about $80^{\circ} \mathrm{C}$ and below, while a good application for flat-plate and evacuated-tube solar thermal systems, are outside the scope of this study. 


\section{Global SIPH Potential, Efforts, and Projects}

In 2012, 45\% of the heat in Organization for Economic Cooperation and Development (OECD) Americas was used by the industrial sector, with the residential sector coming in second at $32 \%$. ${ }^{14}$ In contrast, for the OECD Europe region the reverse was true, where the residential sector makes up $45 \%$ relative to $34 \%$ for the industrial heat demand. In 2012, the U.S. demand for IPH exceeded that for the EU.

The IEA estimates that with concerted collaborative effort, global usage of low-temperature SIPH (e.g., $<120^{\circ} \mathrm{C}$ ) could reach 7.2 exajoules per year $(\mathrm{EJ} / \mathrm{yr})$ by 2050 , with $3,200 \mathrm{GW}_{\text {th }}$ of capacity. ${ }^{15}$ This would be approximately $16 \%$ of the global final energy use for low-temperature heat. China is one of the key countries looking to install significant amounts of solar-thermal collectors to meet the country's industrial and agricultural heat demands. It is expected by 2020 $1.5 \%$ of the entire Chinese industrial and agricultural thermal demand will be supplied by solarthermal sources. ${ }^{16}$

As of 2015, the IEA SHIP database ${ }^{c}$ highlighted 155 projects where solar heat was directly used for industrial processes. ${ }^{17}$ The majority of these projects utilized flat-plate collectors, though the prospect of using concentrating technologies such as PTCs and LFs is gaining interest. The United States currently lists 18 SIPH plants, both with concentrating and nonconcentrating collectors, in the database. This includes 10 SIPH plants utilized for Food and Dairy processing (e.g. fruit drying, milk processing), 4 for the Beverage industry such as breweries, 2 for Desalination \& Water Treatment and 1 for Subway washing. These SIPH solar fields augment and add heat/steam for processes used by these manufacturers. Preliminary research indicates there is significant market for the United States to become a global leader for SIPH, especially in the southwestern states. Figure 2 shows the number of SIPH plants constructed globally since 1980. The spikes in 2008 and 2012 for the United States were from specific SIPH plants, such as the Modesto, CA, Frito Lay plant in 2008 and the St. Pauls, NC, Prestage Foods plant in 2012. ${ }^{18}$

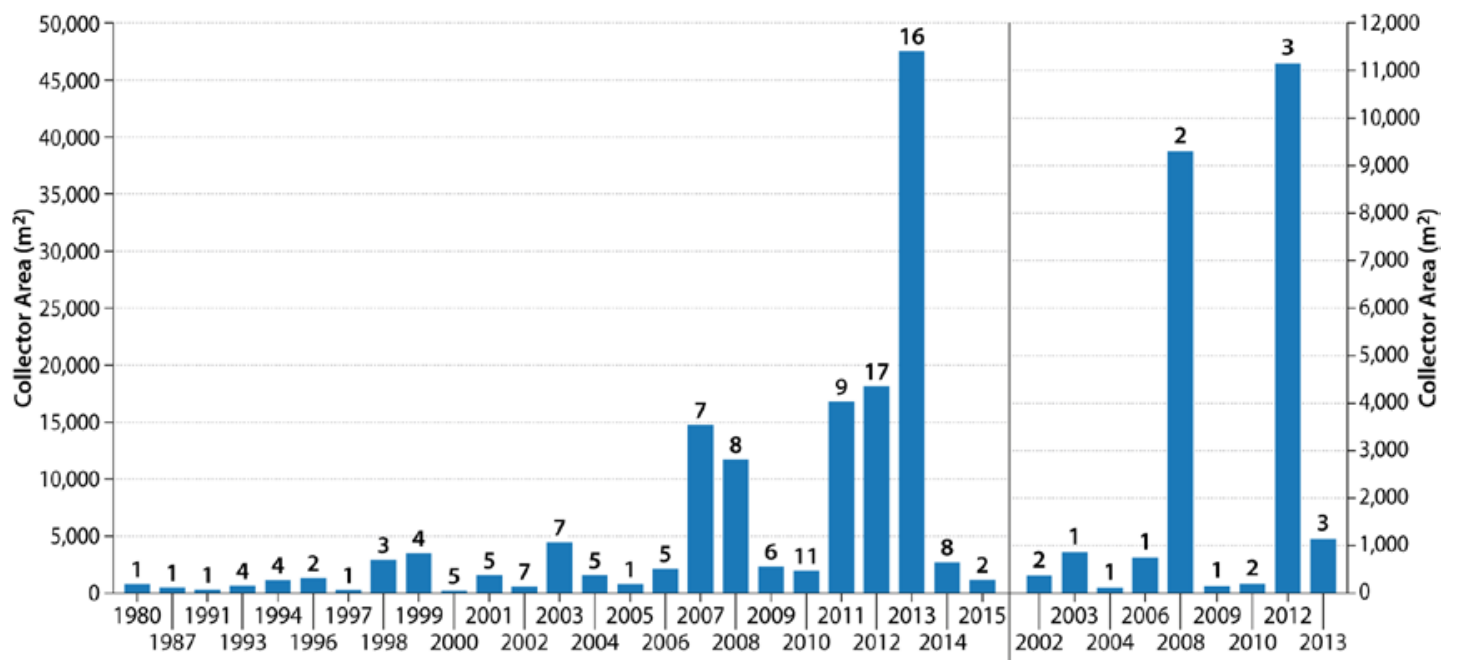

Figure 2. Solar IPH plants built across the world from 1980 to 2015 (left chart) and in the United States (right chart) ${ }^{19}$

\footnotetext{
${ }^{\mathrm{c}}$ The IEA uses the acronym SHIP for "solar heat for industrial processes." This report has referred to these as SIPH
} 


\subsection{Market Studies for the use of SIPH}

Several global studies have been performed to understand both technical and theoretical potential of SIPH needs. ${ }^{20}$ These studies have identified potential heat demands and how solar thermal can be utilized to meet the thermal need of industries. ${ }^{21}$ Countries such as Germany, Spain, Portugal, Italy, and Austria have been leading the analysis. ${ }^{22}$ Tunisian and Mexican studies of SIPH potential have generally considered nonconcentrating solar-thermal collectors. ${ }^{23}$ A 2013 German study found the overall heat demand for German industry that could be theoretically met with solar to be $16 \mathrm{TWh}_{\mathrm{th}} / \mathrm{yr}^{24}$ This accounts for approximately $3.4 \%$ of the overall German industrial heat demand. ${ }^{25}$ For comparison, $16 \mathrm{TWh}$ of thermal energy is the annual thermal output of approximately 46 Nevada Solar One CSP plants ${ }^{\mathrm{d}}$. Another important study in the field of understanding and quantifying solar heat and thermal potential was performed in 2012 in Australia, where heat demand across Australia was detailed for 2,498 industrial sites. ${ }^{26}$

The global studies have also highlighted key industries that could most easily and readily benefit from the integration of steam/heat from solar thermal technologies. These include paper, dairy, food, chemical and washing/cleaning. ${ }^{27}$ The industries identified in the various country studies are found in Appendix A. These global studies on SIPH are used to guide estimates of the potential of SIPH for U.S. industrial heat users.

\subsection{Existing PTC Plants for SIPH}

The IEA's SHIP database compiles known plants where solar-thermal collectors are utilized to provide IPH demands of a site (http://ship-plants.info/). While not extensive and omissions are known, the database provides an estimate on the global situation of SIPH plants. At present, most facilities use nonconcentrating collectors. PTCs are the most prevalent form of concentrating collector for SIPH both in the United States and the world.

Figure 3 highlights the number and the cumulative capacity by country of PTCs utilized for SIPH plants. It is worth noting that few key PTC SIPH plants such as the $10,000 \mathrm{~kW}_{\text {th }}$ Abengoa Solar Minera El Tesoro plant (operating since 2012), used for the "solution heating process for the copper electro-extraction process in the mining production," were not in the SIPH database. ${ }^{28}$ As can be seen in Figure 3, while Mexico has the most PTC SIPH plants (orange dots), the actual solar thermal capacity was relatively low (blue bars). The United States, on the other hand, had only two PTC SIPH plants, but globally amounted for the greatest capacity at approximately $4,028 \mathrm{~kW}_{\text {th. }}$.

\footnotetext{
${ }^{\mathrm{d}}$ Nevada Solar One, built at $64 \mathrm{MW}_{\mathrm{e}}$ capacity, generates about $350 \mathrm{GWh}_{\text {th }}$ per year.
} 


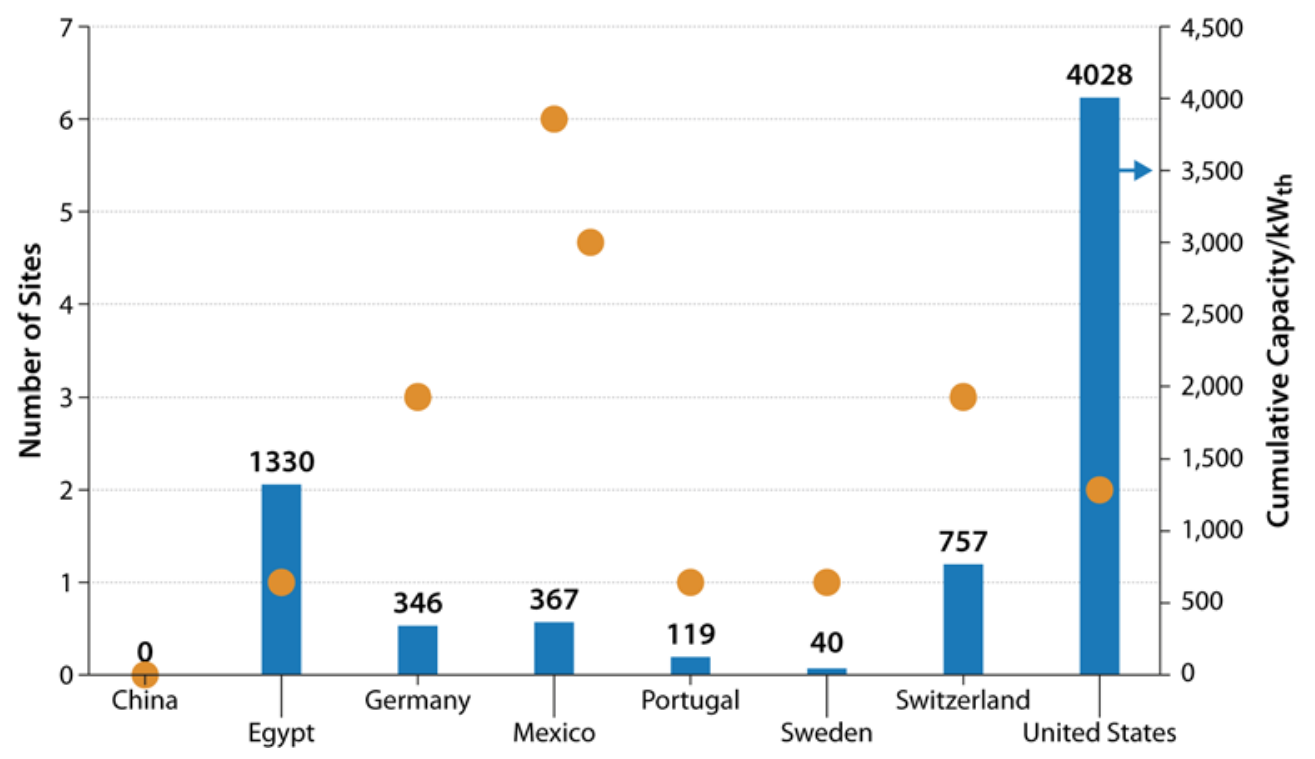

Figure 3. Cumulative number and $\mathbf{k W}_{\text {th }}$ capacity of PTC IPH plants worldwide as of June $2015^{29}$

Figure 4 highlights the capacity breakdown by country and industry of PTC SIPH plants. Significantly, PTCs have predominantly been used at food and dairy processing plants, which may be a combination of the IPH temperatures required and the favorable impression of using solar energy for food production. For the food processing industry as a whole, nearly $3,900 \mathrm{~kW}_{\text {th }}$ of capacity had been installed as of 2015. As of June 2015, the United States had the only operating PTC desalination plant.

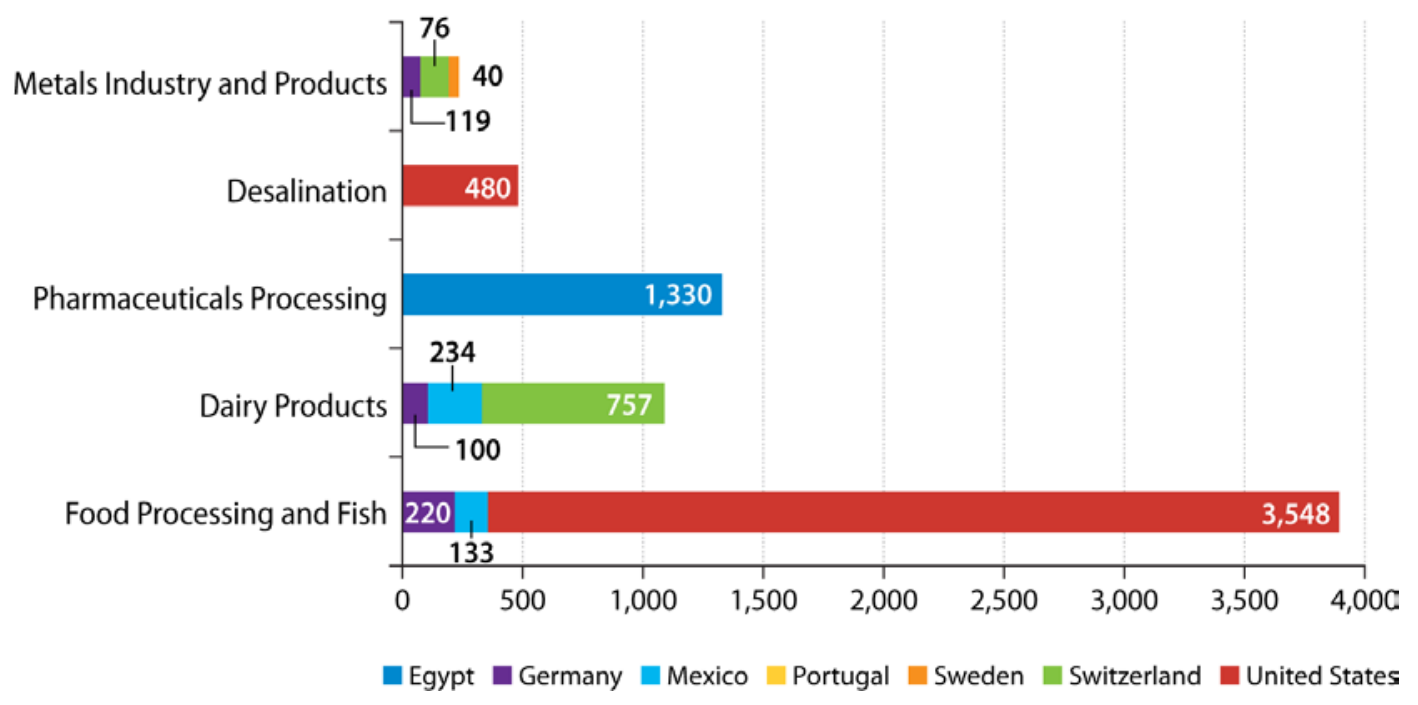

Figure 4. PTC IPH plants across the world by industry served (as of May 2015) ${ }^{30}$

\subsection{Global Examples of Concentrating SIPH Systems}

With regards to utilizing concentrating solar technologies for IPH, there are several examples which highlight that potential can be met and that SIPH is an economically viable option. In 2014, there were fifteen PTC and four LF projects supplying process heat for a variety of 
applications and temperatures. ${ }^{31}$ The dairy industry in Switzerland utilized PTCs for milk processing for three projects. The Cremo SA manufacturing plant, seen in Figure 5, has roofmounted PTCs to heat water for two processes. The rooftop solar field provides $170^{\circ} \mathrm{C}$ steam for the high temperature process of sterilization and $125^{\circ} \mathrm{C}$ steam for milk processing/heating the supply line. ${ }^{32}$

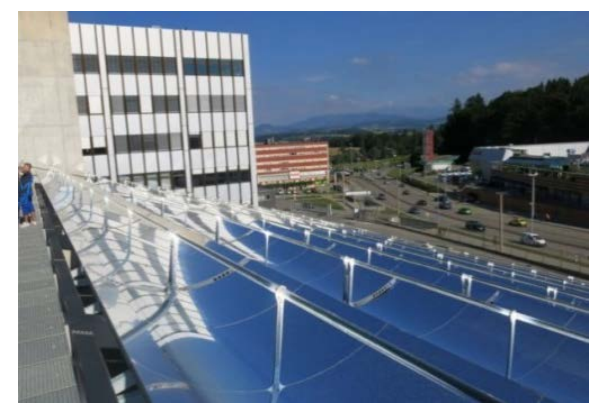

Figure 5. CSP PTCs used for generating heat at the Cremo SA milk processing centre

SolarLite CSP Technology GmbH (Duckwitz, Germany) has specifically targeted the SIPH market with their SL 4600 trough suited for temperatures up to about $250^{\circ} \mathrm{C}^{33}$ A 2014 Solarlite case study of a brewery in southern Europe highlighted that the brewery produced an average 1.4 million hectoliters ( $\sim 37$ million gallons) of beer per year and utilized approximately 4.5 million $\mathrm{m}^{3}$ of natural gas per year. For the brewery, the natural gas was approximately $15 \%$ of the total brewery's annual cost, amounting to $€ 2.5 \mathrm{M}(\$ 2.7 \mathrm{M})$ per year. ${ }^{34}$ With the implementation and integration of the PTCs to provide significant thermal energy for the otherwise gas-fired boilers (which produce steam at 8 bar and $170^{\circ} \mathrm{C}$ ), the brewery has reportedly saved $€ 0.54 \mathrm{M}(\$ 0.59 \mathrm{M})$ per year for an investment of $€ 3.75 \mathrm{M}(\$ 4.11 \mathrm{M})$. The estimated simple payback was seven years for this industrial-scale application. The case highlights the applicability for breweries as an industry of interest for SIPH. SolarLite has expansion plans and a pipeline of activity for the United States, Europe, and the Middle East. As of 2014, Solarlite reported a pipeline of nearly $100 \mathrm{MW}_{\text {th }}$ for Australia and were also testing the use of biomass combined with CSP for IPH. ${ }^{35}$ Figure 6 shows the SL 4600 at the $5 \mathrm{MW}_{\mathrm{e}}$ TSE1 site in Thailand, where SolarLite is utilizing the troughs for direct steam generation (DSG).
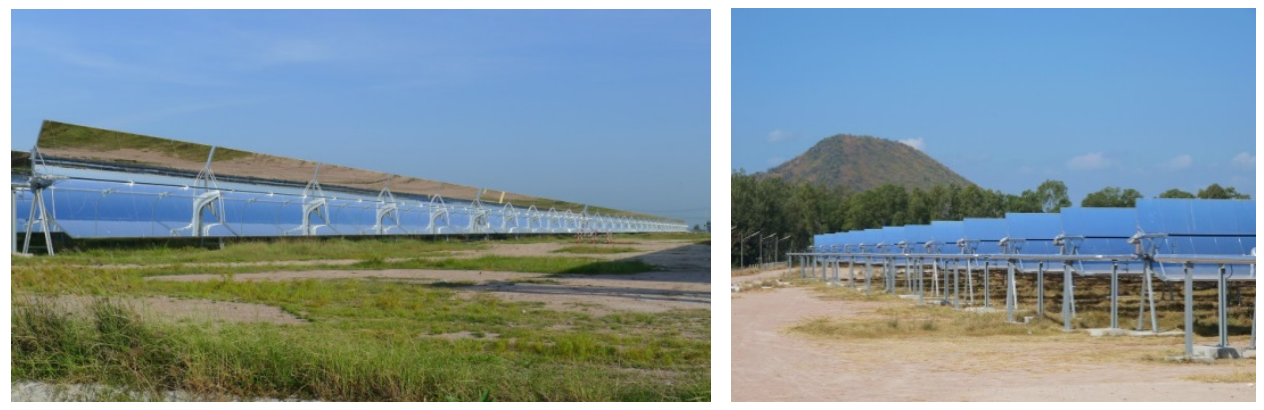

Figure 6. TSE1 site in Thailand where the Solarlite SL 4600 s were being utilized for DSG ${ }^{36}$

Linear Fresnel systems are also being investigated and deployed for SIPH. For example, in Jordan, the commissioning of an Industrial Solar (Freiburg, Germany) LF-11 Fresnel collector system occurred in May 2015. This roof-based system reportedly has a peak capacity of 223 $\mathrm{kW}_{\text {th }}$ to provide steam directly to a pharmaceutical production process and decrease fuel consumption and $\mathrm{CO}_{2}$ emissions. ${ }^{37}$ In Italy, an LF collector system was inaugurated that can 
generate $600 \mathrm{MWh}_{\mathrm{th}} / \mathrm{yr}$, save 180 tons per year of $\mathrm{CO}_{2}$ emissions, and save 50,000 L of fuel oil per year. ${ }^{38}$ This was built for the 'Nuova Sarda Industria Casearia' (cheese and dairy production plant) in Sardinia. ${ }^{39}$ An LF system similar to that used at the cheese factory is shown in Figure 7.

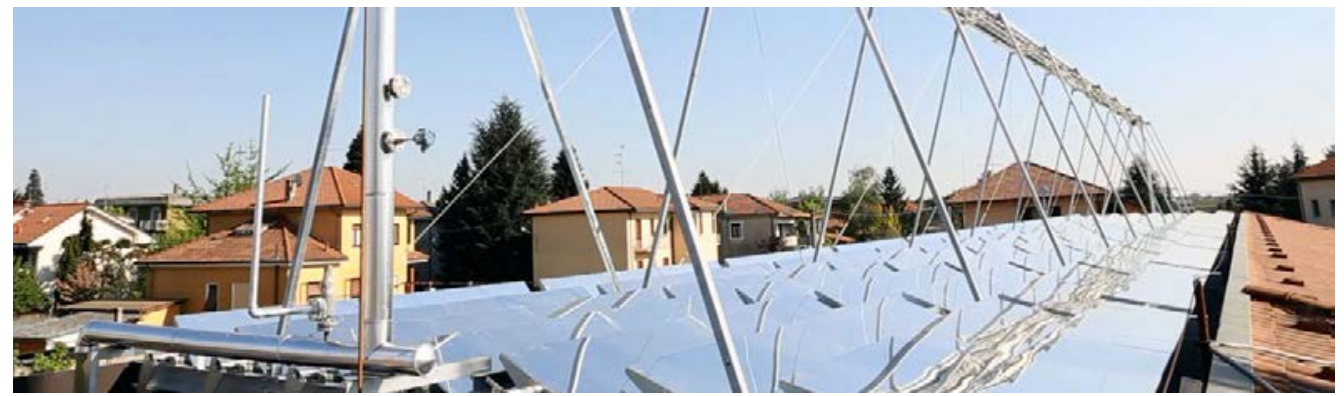

Figure 7. LF system installed on a roof ${ }^{40}$

One of the recent applications of SIPH is enhanced oil recovery (EOR), where GlassPoint (Fremont, CA) is one of the leaders. Crude oil production typically includes three stages of primary, secondary, and tertiary recovery, where the tertiary stage utilizes EOR techniques to increase the production of crude oil from the residual oil in the reservoir that the primary and secondary techniques could not extract.$^{41}$ The oil recovery factor, which is the amount of oil that can be recovered from the original well can increase from $25 \%$ using primary techniques to 30 $70 \%$ using EOR..$^{42}$ One of the main EOR techniques utilizes the injection of steam into aging oil fields to boost the extraction of residual oil reserves. ${ }^{43}$ In oil-producing regions with good DNI, such as southern California or the Middle East, EOR is ideally coupled with solar thermal to produce and inject modest-pressure saturated steam. Convenient for the solar-steam application, continuous injection is not always required. ${ }^{44}$

The GlassPoint design encloses PTCs within a greenhouse-like structure to keep the reflectors clean and eliminate wind loading on the reflectors. Placing the PTCs inside a commercial glasshouse that was mass produced for the agricultural industry has advantages, such as a potential 20\% reduction in steel and reduced O\&M costs. ${ }^{45}$ The primary benefit of the solarthermal EOR is significant saving of natural gas that would normally be used for the steam production. GlassPoint claims that, in the situation where constant rate steaming is used (i.e., steam is injected into the well at a constant rate with solar heat in the day and gas for the night), the potential natural gas reduction could be $25 \% .{ }^{46}$ For the case of variable rate steaming (i.e., where the natural gas provides a base rate of steam and solar DSG injects a greater quantity during the day), the potential natural saving can be up to $80 \%{ }^{47}$ The largest GlassPoint site to date is the $7 \mathrm{MW}_{\text {th }}$ Petroleum Development Oman (PDO) site, which has been reported to deliver 50 tons of steam a day at a gas savings of 47,000 MMBtu per year. ${ }^{48}$ GlassPoint recently announced a 1,021 $\mathrm{MW}_{\text {th }}$ EOR project in Oman that would become the largest solar thermal plant in the world. ${ }^{49}$

Other CSP players vying for projects in solar-thermal EOR include power tower developers such as eSolar and Brightsource. ${ }^{50}$ BrightSource's Coalinga $27 \mathrm{MW}_{\text {th }}$ demonstration site was used to test power tower technologies while providing steam injection for recovery of heavy oil reserves in southern California. ${ }^{51}$ Much of the knowledge gained at the site was applied to the electric power sector at the Ivanpah plant. Tower technologies can achieve higher steam temperatures 
than linear-focus systems such as PTCs; their advantage at lower steam temperatures (e.g., less than $400^{\circ} \mathrm{C}$ ) is not clear.

\subsection{Temperature Ranges for SIPH}

As illustrated in Figure 1, different solar thermal collectors have different temperature capabilities. Table 2 lists different temperature ranges and the most likely solar collectors to supply IPH at those conditions.

Table 2. Temperature regions relevant for SIPH

\begin{tabular}{|l|l|l|l|}
\hline $\begin{array}{l}\text { Temperature } \\
\text { Range* }\end{array}$ & Solar Collector Type & HTF of Choice & Applications/Comments \\
\hline$<80^{\circ} \mathrm{C}$ & $\begin{array}{l}\text { Flat plate } \\
\text { Non-tracking compound } \\
\text { parabolic } \\
\text { Solar pond }\end{array}$ & Water & $\begin{array}{l}\text { Hot water } \\
\text { Space heating }\end{array}$ \\
\hline 80 to $200^{\circ} \mathrm{C}$ & $\begin{array}{l}\text { Parabolic trough } \\
\text { Linear Fresnel }\end{array}$ & Water/steam & Hot water or steam for IPH \\
\hline 200 to $300^{\circ} \mathrm{C}$ & $\begin{array}{l}\text { Parabolic trough } \\
\text { Linear Fresnel }\end{array}$ & Mineral oil & $\begin{array}{l}\text { Direct heat or steam for IPH } \\
\text { Vacuum-jacket receivers } \\
\text { become necessary to minimize } \\
\text { heat loss }\end{array}$ \\
\hline 300 to $400^{\circ} \mathrm{C}$ & $\begin{array}{l}\text { Parabolic trough } \\
\text { Linear Fresnel }\end{array}$ & $\begin{array}{l}\text { Synthetic oil } \\
\text { Direct heat or steam for IPH }\end{array}$ \\
\hline 400 to $550^{\circ} \mathrm{C}$ & $\begin{array}{l}\text { Parabolic trough } \\
\text { Linear Fresnel }\end{array}$ & $\begin{array}{l}\text { Steam or } \\
\text { Molten salt }\end{array}$ & Electric power \\
\hline$>550^{\circ} \mathrm{C}$ & $\begin{array}{l}\text { Heliostat/central receiver } \\
\text { Parabolic dish }\end{array}$ & $\begin{array}{l}\text { Steam or } \\
\text { Molten salt }\end{array}$ & Electric power \\
\hline
\end{tabular}

* This study focuses on temperatures between $100^{\circ} \mathrm{C}$ and $400^{\circ} \mathrm{C}$, where linear-focus collectors excel and IPH demand is high. See following section for information on HTF choice throughout this range.

Temperatures below about $80^{\circ} \mathrm{C}$ can be achieved with non-tracking, non-concentrating devices such as solar ponds and flat-plate collectors to supply hot water, swimming pool heating, or space heating. While such applications are excellent matches for solar energy, the development and deployment of these systems are outside the scope of this study, which is dedicated to identifying alternative markets for concentrating solar collectors.

At the other end of the spectrum, temperatures above about $550^{\circ} \mathrm{C}$ exceed the limit of linearconcentrating systems and require the use of point-focus systems such as parabolic dishes and central receivers. These units most often deploy molten salt or high-pressure steam as the heat transfer fluid, although some designs have been tested with air.

The region of interest for the present study is the realm of temperatures that can be achieved with tracking, linear-focus collectors. These collectors have a proven track record, utilize simple oneaxis tracking, and can be deployed in a modular fashion by adding additional collector length. The optics of linear-focus systems can achieve temperatures up to about $550^{\circ} \mathrm{C}$. However, as one 
moves to higher temperatures, the requirements for the HTF and the receiver become more restrictive, which generally means more expensive hardware and fluids are required.

\subsubsection{Candidate HTFs}

Among the many possible HTFs, pressurized water, ethylene glycol, and mineral oil are reasonable candidates for SIPH applications based on their physical properties and cost. The organic fluids are generally available from a number of vendors under various tradenames. For example, the synthetic oil eutectic mixture of biphenyl and diphenyl ether-commercially sold as Dowtherm A and Solutia VP-1 - is the HTF of choice for current parabolic trough CSP plants. Table 3 summarizes the physical properties and approximate cost of these HTFs. Pressurized water cost assumes boiler-grade water generated from ion exchange or reverse osmosis. The cost for pressurized water listed in Table 3 is equivalent to about $\$ 3$ per 1,000 gallons.

Propylene glycol was considered in addition to ethylene glycol. Its viscosity is higher than that of ethylene glycol, its boiling point $\left(187^{\circ} \mathrm{C}\right)$ is slightly lower, and its cost is higher, so ethylene glycol was chosen as the best glycol fluid. Propylene glycol is generally used as a replacement for ethylene glycol where toxicity and biodegradation are important considerations, so this fluid may be an appropriate option in food processing applications.

HTF storage cost in Table 3 is the cost of the fluid per unit of stored thermal energy assuming sensible storage with a temperature differential of $150 \mathrm{~K}$. Ethylene glycol, mineral oil, and glycerin have about the same cost per unit of stored thermal energy. At temperatures up to $200^{\circ} \mathrm{C}$, all of the organic fluids can be stored in tanks at less than 2 bar absolute, which is considered low-pressure storage. Pressurized water clearly has the lowest storage cost when considering only the cost of the stored fluid. However, its vapor pressure increases tank costs, which must be considered when estimating the cost of the full TES system.

Table 3. Physical properties and costs for candidate HTFs

\begin{tabular}{lcccccc} 
HTF & $\begin{array}{c}\text { Melting/ } \\
\text { Pour } \\
\text { Point } \\
\left({ }^{\circ} \mathbf{C}\right)\end{array}$ & $\begin{array}{c}\text { Boiling } \\
\text { Point } \\
\left({ }^{\circ} \mathbf{C}\right)\end{array}$ & $\begin{array}{c}\text { Vapor } \\
\text { Pressure } \\
\text { at } \mathbf{2 0 0}{ }^{\circ} \mathbf{C} \\
(\mathbf{b a r})\end{array}$ & $\begin{array}{c}\text { Max } \\
\text { Rec'd } \\
\text { operating } \\
\text { Temp }\end{array}$ & $\begin{array}{c}\text { Cost } \\
(\mathbf{\$} \text { US/MT) }\end{array}$ & $\begin{array}{c}\text { Storage } \\
\text { Cost } \\
(\mathbf{\$} / \mathbf{k W h} \text { th })\end{array}$ \\
\hline Pressurized Water & 0 & 100 & 15.5 & Unlimited & 0.8 & 0.004 \\
\hline Ethylene Glycol & -13 & 197 & 1.11 & $\sim 240^{\circ} \mathrm{C}$ & 1400 & 12 \\
\hline Mineral Oil & -12 & $>355$ & 0.01 & $\sim 300^{\circ} \mathrm{C}$ & 1500 & 16 \\
\hline Dowtherm A/VP-1 & 12 & 257 & 0.24 & $\sim 390^{\circ} \mathrm{C}$ & 4300 & 55 \\
\hline
\end{tabular}

Table 4 lists the temperature-dependent properties of the candidate fluids from $50^{\circ} \mathrm{C}$ to $200^{\circ} \mathrm{C}$. All candidate fluids have acceptable heat capacities, densities, volumetric heat capacities, and thermal conductivities. The high viscosity of mineral oil at $50^{\circ} \mathrm{C}$ will cause its pumping costs to be high relative to water and ethylene glycol. These factors suggest ethylene glycol as the most promising fluid if low-pressure storage is preferred. 
Table 4 Temperature-dependent properties for candidate HTFs.

\begin{tabular}{|c|c|c|c|c|c|c|}
\hline $\operatorname{Temp}\left({ }^{\circ} \mathrm{C}\right)$ & $\begin{array}{c}\text { Vapor } \\
\text { Pressure } \\
\text { (bar) }\end{array}$ & $\begin{array}{c}\text { Heat } \\
\text { Capacity } \\
(\mathrm{J} / \mathrm{g}-\mathrm{K})\end{array}$ & $\begin{array}{l}\text { Density } \\
\left(\mathrm{kg} / \mathrm{m}^{3}\right)\end{array}$ & $\begin{array}{l}\text { Vol. Heat } \\
\text { Capacity } \\
\left(\mathrm{kJ} / \mathrm{m}^{3}-\mathrm{K}\right)\end{array}$ & $\begin{array}{l}\text { Viscosity } \\
\text { (cP) }\end{array}$ & $\begin{array}{c}\text { Conductivity } \\
(\mathrm{W} / \mathrm{m}-\mathrm{K})\end{array}$ \\
\hline \multicolumn{7}{|c|}{ Pressurized water } \\
\hline 50 & 0.134 & 4.183 & 992.7 & 4,152 & 0.560 & 0.629 \\
\hline 100 & 1.013 & 4.217 & 958.4 & 4,042 & 0.282 & 0.665 \\
\hline 150 & 4.900 & 4.313 & 916.9 & 3,955 & 0.184 & 0.668 \\
\hline 200 & 15.54 & 4.489 & 864.8 & 3,882 & 0.134 & 0.651 \\
\hline \multicolumn{7}{|c|}{ Ethylene Glycol } \\
\hline 50 & $<0.001$ & 2.53 & 1,100 & 2,781 & 6.5 & 0.266 \\
\hline 100 & 0.02 & 2.78 & 1,055 & 2,929 & 2.0 & 0.229 \\
\hline 150 & 0.20 & 3.02 & 1,015 & 3,070 & 0.9 & 0.191 \\
\hline 200 & 1.11 & 3.27 & 965 & 3,158 & 0.5 & 0.154 \\
\hline \multicolumn{7}{|c|}{ Mineral Oil (Shell Thermia B) } \\
\hline 50 & $<0.001$ & 1.95 & 850 & 1,661 & 21 & 0.133 \\
\hline 100 & $<0.001$ & 2.17 & 811 & 1,762 & 3.8 & 0.128 \\
\hline 150 & $<0.001$ & 2.35 & 778 & 1,832 & 1.7 & 0.125 \\
\hline 200 & 0.005 & 2.54 & 746 & 1,893 & 0.90 & 0.121 \\
\hline 250 & 0.026 & 2.72 & 713 & 1,940 & 0.61 & 0.118 \\
\hline \multicolumn{7}{|c|}{ Dowtherm A/VP-1 } \\
\hline 100 & 0.004 & 1.77 & 999 & 1,770 & 0.99 & 0.128 \\
\hline 150 & 0.045 & 1.91 & 957 & 1,828 & 0.59 & 0.121 \\
\hline 250 & 0.87 & 2.18 & 867 & 1,890 & 0.29 & 0.105 \\
\hline 350 & 5.48 & 2.45 & 761 & 1,864 & 0.18 & 0.086 \\
\hline
\end{tabular}

Table 5 lists safety and environmental factors for the candidate fluids. All the fluids are relatively low-risk. Water and mineral oil pose the least risk to the environment. In the absence of thermal storage, pressurized water is the clear winner for the $\mathrm{HTF}$ choice at conditions near $200^{\circ} \mathrm{C}$. It offers superior physical properties, lower hazards, and less cost compared to the organic fluids. At higher temperatures, solar thermal collectors can produce steam directly or use an organic mineral oil if a liquid HTF is desired. The greater risk and cost of synthetic oils is generally not justified unless temperatures greater than about $300^{\circ} \mathrm{C}$ are required. As will be shown, most SIPH applications are at temperatures less than that temperature. 
Table 5. Safety/environmental characteristics of candidate heat-transfer fluids based on U.S. National Fire Protection Association (NFPA) ratings. NFPA rankings range from no risk (0) to high risk (4).

\begin{tabular}{lcccccc} 
HTF & $\begin{array}{c}\text { High- } \\
\text { Pressure } \\
\text { at 200 }\end{array}$ & $\begin{array}{c}\text { NFPA } \\
\text { Flammability } \\
\text { Risk }\end{array}$ & $\begin{array}{c}\text { NFPA } \\
\text { Health } \\
\text { Risk }\end{array}$ & $\begin{array}{c}\text { NFPA } \\
\text { Reactivity }\end{array}$ & $\begin{array}{c}\text { Corrosive } \\
\text { Risks }\end{array}$ \\
\hline $\begin{array}{l}\text { Pressurized } \\
\text { Water }\end{array}$ & Yes & 0 & 0 & 0 & No & None \\
$\begin{array}{l}\text { Ethylene } \\
\text { Glycol }\end{array}$ & No & 1 & 2 & 1 & No & Low \\
Mineral Oil & No & 1 & 0 & 0 & No & Very low \\
$\begin{array}{l}\text { Dowtherm } \\
\text { A/VP-1 }\end{array}$ & No & 1 & 2 & 0 & No & Low \\
\hline
\end{tabular}




\section{Methodology}

There are two primary methods researchers have adopted to analyze the potential for SIPH-a top-down approach or a bottom-up approach. While there are general differences in the methodologies, there are marked similarities as the aim is to understand a level of potential for SIPH. Both methods are looking to match the industrial heat and steam demand with a supply of solar-thermal energy. Understanding the conventional energy source (e.g., natural gas, waste heat, or electricity) is required to assess the economic potential.

It is worth highlighting there are different levels and meanings of 'potential'. The raw resource potential considers only DNI and land area. The second level, as defined in a prior NREL study, is the technical potential, where estimated technology-specific performance, topographic, and land-use constraints are applied. This report uses similar constraints that were used in the 2012 NREL study. ${ }^{52}$ Realizable potential is related to technical potential, though further assessments and constraints are added to scale back the technical potential to a more likely target. ${ }^{53}$ Economic and market potential, as defined by the DOE EERE Potential Pyramid, take technical and realizable potential and add constraints such as projected fuel costs, technology costs, and policy implications of siting a project in a specific area. ${ }^{54}$ This investigation considers the raw resource and technical thermal energy potentials in the U.S. Southwest. Promising regions identified in this study would be prime candidates for potential follow-on, site-specific analysis.

\subsection{Top-Down vs. Bottom-Up Analysis}

Several studies have undertaken a top-down approach to understand and quantify the SIPH potential in a particular country. For example, a top-down approach was used by German researchers for a recent SIPH evaluation. ${ }^{55}$ The top-down approach examines from the country level the industries and applications that require the use of IPH. This demand for IPH is then compared with the available supply of solar-thermal energy based on resource data and land availability in proximity to the user industries. Various constraints and incentives can be applied to try to arrive at a realistic target for SIPH potential.

The bottom-up approach has been utilized by several countries in quantifying SIPH potential, including Australia, Spain, and Portugal. ${ }^{56}$ Here, a detailed investigation is undertaken on specific sites or companies to determine suitable sectors for SIPH, and then parallels are made to the larger industry. The benefits of this approach include a more accurate estimate of solar potential that can be provided for the given site and space restrictions; however, such analysis requires more time and effort and is necessarily limited in extent. A bottom-up approach is most useful once likely applications have been identified via the broader, top-down analysis.

This study chose to undertake a top-down approach of the potential for SIPH, primarily because it gives a good overview of opportunity derived from the solar resource potential and relevant industries in the region. The purpose was to test the hypothesis that U.S. areas with high DNI also contain a direct industrial need for steam due to the high consumption of natural gas. Figure 8 highlights the steps used to understand the thermal energy demand and the technical thermal energy potential for SIPH, with the geographic extent narrowed to the state of California. California was selected due to its strong DNI resource, the evidence of high natural gas consumption for industrial steam, and policies favorable to deployment of renewable energy technologies. 

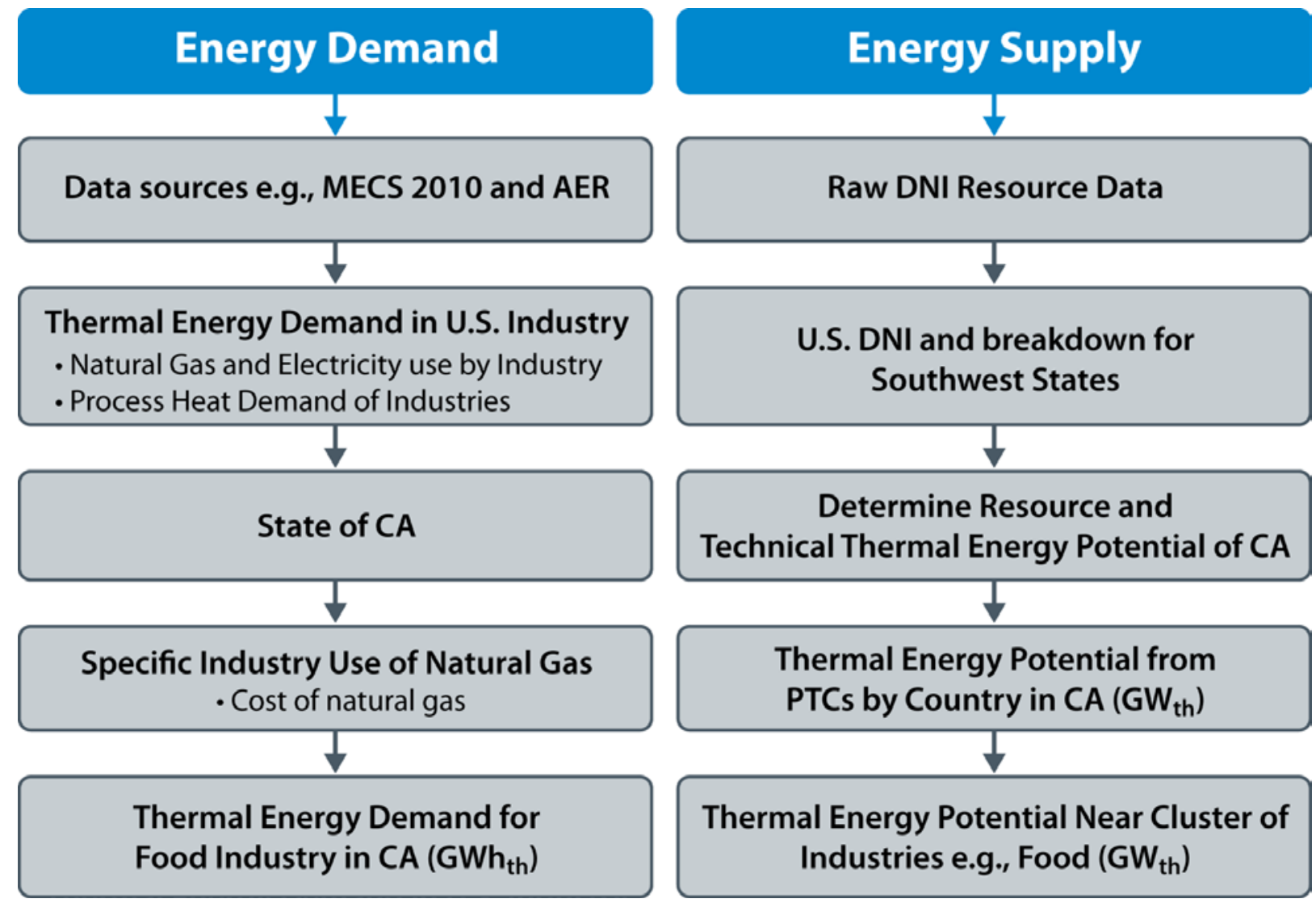

Figure 8. Methodology developed for this study to determine U.S. SIPH potential with an example of the food industry in California

The proximity of supply site and demand site is more important for SIPH than solar generation of electricity. Unlike electric power generation, the application of SIPH requires co-location of the solar field and the thermal-energy consumer. Accordingly, the majority of SIPH deployments are on land adjacent to the plant or on the facility roof itself. This is because the distribution of hot fluids, such as steam, is limited to short distances (hundreds of meters), while electricity distribution lines may run for hundreds of kilometers.

The top-down approach provides a good overall assessment of whether further research should be undertaken for an area or industry - without the commitment of time and resources necessary to undertake a detailed bottom-up analysis. For example, the bottom-up approach as undertaken in Australia, ${ }^{57}$ is a more accurate representation of site-specific potential, but it is most useful in conjunction with an initial top-down analysis. The top-down analysis can provide the raw resource and technical potential in a given geographic area and so provides initial indications where to focus further efforts and undertake detailed bottom-up analysis at specific industrial sites to determine whether the industrial users' requirements for process heat can be met by the supply of solar energy.

\subsection{Limitations for the Chosen Method and Study}

For the purpose of this report, the energy calculations and industrial snapshots will be limited to the southwestern United States. The states included in this definition are California, Arizona, 
Nevada, New Mexico, Utah, Colorado, and Texas (i.e., regions with the greatest annual average DNI) ${ }^{58}$ California is then singled out for more detailed consideration due to its emphasis and policy on deploying more solar technology.

The U.S. Manufacturing Energy Consumption Survey (MECS) 2010 data set is utilized for estimates of fuel and energy consumption in the industrial sector. The data set is for industries classified with the NAICS codes 31-33; see Table 6. Natural gas has been chosen as the main fuel for analysis as the majority of the MECS industries utilize natural gas as the prime fuel rather than coal or oil. Natural gas is also the most consumed fuel for direct process heating and conventional boiler use (i.e., steam production). The electricity used for direct process heating and conventional boiler use is a relatively small portion when compared to natural gas. For the calculations, only the specific fuel consumptions for the sub-categories of direct process heating and boiler use have been considered by industry and location. While natural gas is most prevalent and selected as the primary IPH fuel, applications where natural gas is not available and other energy sources, such as fuel oil, propane, or electricity are used would be prime candidates for adoption of SIPH due to the higher relative costs of those energy sources.

Table 6. List of Specific Industries Included in the MECS (NAICS Codes 31-33)

\begin{tabular}{|l|l|}
\hline NAICS Code & Individual Sector Title \\
\hline 311 & Food Manufacturing* \\
\hline 312 & Beverage and Tobacco Product Manufacturing \\
\hline 313 & Textile Mills \\
\hline 314 & Textile Product Mills \\
\hline 315 & Apparel Manufacturing \\
\hline 316 & Leather and Allied Product Manufacturing \\
\hline 321 & Wood Product Manufacturing \\
\hline 322 & Paper Manufacturing* \\
\hline 323 & Printing and Related Support Activities \\
\hline 324 & Petroleum and Coal Products Manufacturing* \\
\hline 325 & Chemical Manufacturing* \\
\hline 326 & Plastics and Rubber Products Manufacturing \\
\hline 327 & Nonmetallic Mineral Products Manufacturing \\
\hline 331 & Primary Metal Manufacturing* \\
\hline 332 & Fabricated Metal Product Manufacturing \\
\hline 333 & Machinery Manufacturing \\
\hline 334 & Computer and Electronic Product Manufacturing \\
\hline 335 & Electrical Equipment, Appliance and Component Manufacturing \\
\hline 336 & Transportation Equipment Manufacturing \\
\hline 337 & Furniture and Related Product Manufacturing \\
\hline 338 & Technical Instrumentation \\
\hline 339 & Miscellaneous Manufacturing \\
\hline
\end{tabular}

* top five industrial steam user 
Previous research into the industries with the greatest steam demand has found that food, paper, petroleum, chemical, and primary metals industries were the largest consumers of steam. ${ }^{59}$ For this report, any other fuel sources or contributions to steam from fuel byproducts such as naphtha, as well as End-Use Not Reported (EUNR) categories, were excluded. The data have been further confined to steam applications less than $260^{\circ} \mathrm{C}$. Steam at less than $260^{\circ} \mathrm{C}$ can easily be provided by concentrating collectors and solar-thermal. Although steam is used in industrial applications with temperatures up to $380^{\circ} \mathrm{C}$, the pressure requirement for it often makes its generation and distribution impractical at these temperatures.

PTCs have been selected as the primary solar-thermal collectors, and the thermal potential is based on trough performance models. This is not to imply that LFs are not a valid solar-thermal option; however, more data exist for parabolic troughs. A prior NREL solar-resource study utilized PTC models to undertake theoretical energy potential analysis, ${ }^{60}$ and those data are applied for the present analysis. The present study assumes performance based on PTCs with a solar multiple of 1.4 and without thermal energy storage. As per the 2012 study, a land constriction of one square kilometer has been maintained. While suitable for electricity generation plants, this minimum-land-area constraint is overly restrictive for SIPH applications. However, as will be shown, solar resource is not a limiting factor in the top-down analysis. If the work progresses to a bottom-up analysis of specific cases, a finer resolution model will be employed for the local resource assessment.

Large-aperture troughs are mature and efficient technology, but may not be the collector of choice with smaller, lower-temperature SIPH applications where weight, wind-profile, ease-ofassembly, or other metrics may take on greater importance. Nonetheless, the large trough models provide a reasonable estimate of thermal performance. Discussions with SIPH developers and further research into collectors designed for process heat applications will refine performance estimates in modeling SIPH systems. 


\section{U.S. Demand for IPH}

The U.S. manufacturing sector has three primary energy sources: fuel, steam generation, and electricity generation (Figure 9). A fourth category, onsite renewable electricity generation, makes up only $0.04 \%$ of this total. As can be seen, fuel (e.g., natural gas, fuel oil, coal, etc.) accounted for nearly $57 \%$ of the primary energy input, with extensive use for process energy, either directly or via onsite steam generation. Approximately 5,016 TBtu of fuel were consumed by the MECS industries in 2010 to produce direct process energy, with a slightly smaller quantity (about 3,000 TBtu) consumed for steam generation for process energy. The approximate $8,000 \mathrm{TBtu} / \mathrm{yr}$ of fuel for process energy represents approximately $42 \%$ of the total primary energy consumption in the U.S. manufacturing sector.

\section{U.S. Manufacturing Sector (TBtu), 2010}

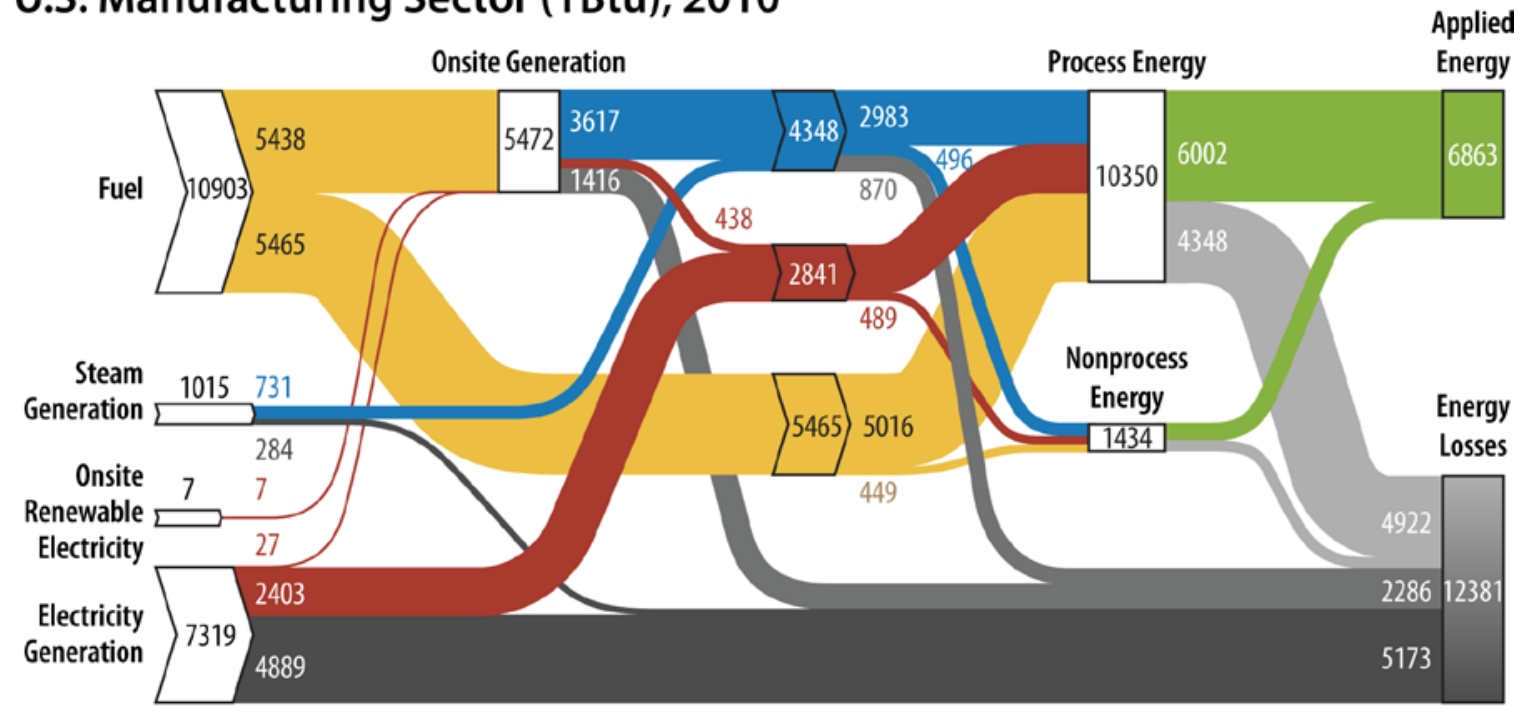

LEGEND: $\quad$ Fuel $\square$ Steam $\square$ Electricity $\square$ Applied Energy $\square$ Offsite Generation and Transmission Losses - Onsite Generation and Distribution Losses End Use Losses

Figure 9. Sankey diagram of the annual primary energy flow in the U.S. manufacturing sector ${ }^{61}$

In Figure 9, process energy refers to elements such as process heating, process cooling and refrigeration, and machine drive. The category of process energy is further divided in Figure 10; the five major components being process heating, process cooling and refrigeration, machine drive, electro-chemical, and other processes. Electricity usage within the process energy category is mainly for non-heating applications that could not be replaced with solar heat. 


\section{Process Energy (TBtu), 2010}

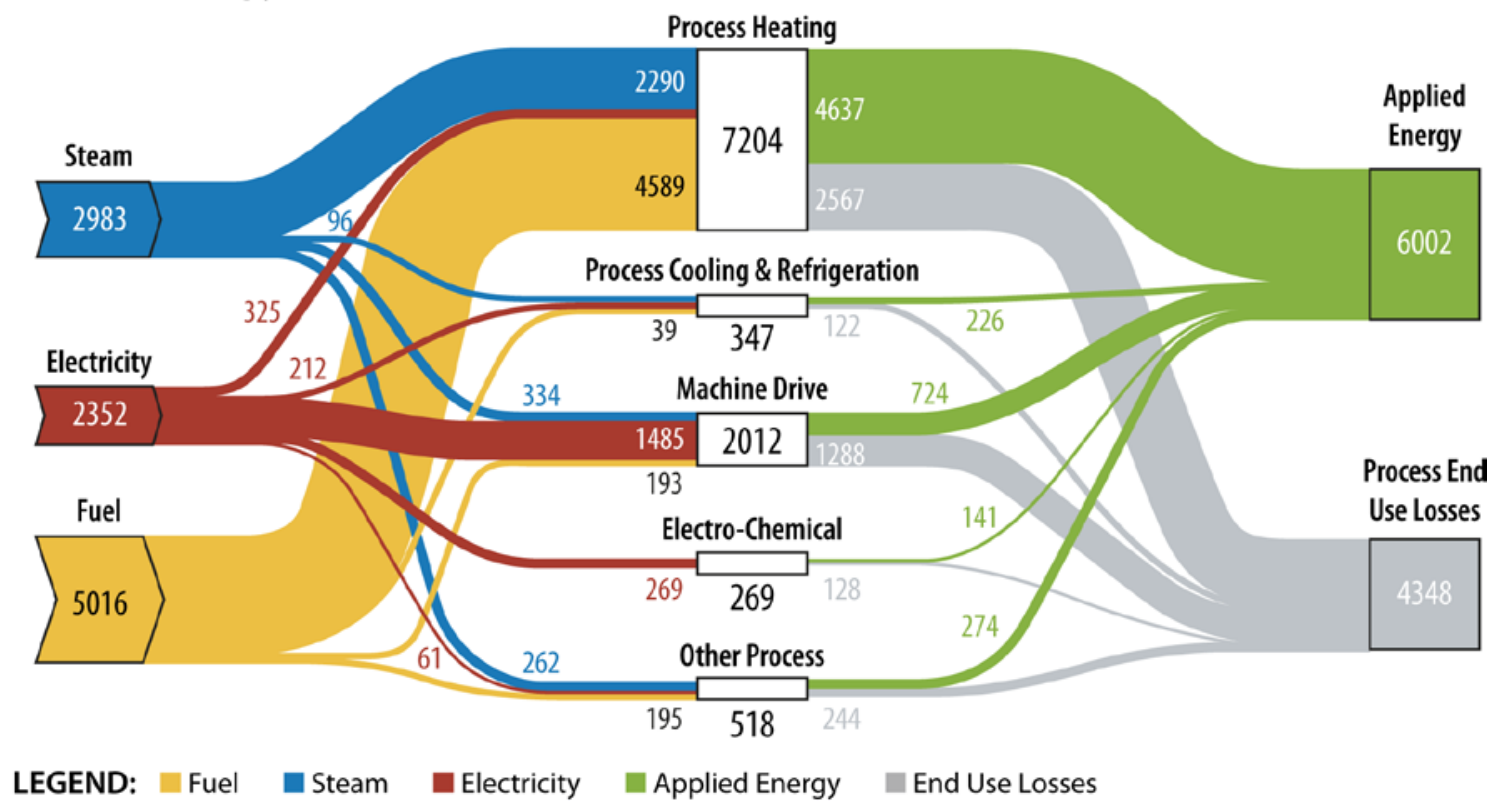

Figure 10. Sankey Diagram of annual process energy flow in U.S. manufacturing sector. ${ }^{62}$ Process energy is a subset of primary energy (see Figure 9).

From Figure 10, it is clear the importance of process heating within process energy as a whole. For 2010, the U.S. manufacturing sector utilized 7,204 TBtu for process heat generated from steam, electricity and fuel, or approximately $70 \%$ of the total process energy consumed in the manufacturing sector and $29 \%(0.70 * 0.42)$ of the primary energy consumed in the sector. Breaking down the energy consumed as fuel for process heating across the United States, nearly 4,589 TBtu/yr was consumed via direct fuel use for process heating. When the direct and indirect (e.g., fuel used to generate steam) consumption of fuel is considered, the MECS industries effectively demanded 6,879 TBtu/yr of fuel for process heating, or nearly $95 \%$ of all the process heating energy demand. This energy demand represents the annual thermal output of about 5,700 solar fields of the size used at the Nevada Solar One CSP plant. Clearly, a significant opportunity exists for the replacement of fossil-fired thermal energy.

The MECS 2010 data provide the industrial breakdown of the energy end use by energy type and end-use category. Figure 11 highlights the breakdown of the energy used within the MECS industries by the fuel type. Natural gas and electricity represent over $87 \%$ of the fuel consumed by all the MECS industries in the United States. Natural gas within the MECS industries was the fuel most consumed in $2010(5,211 \mathrm{TBtu} / \mathrm{yr}$ of natural gas was consumed or $56 \%$ of the entire MECS industries fuel consumption in the United States). ${ }^{63}$ 


\section{MECS 2010 Energy Consumption by Fuel Type}

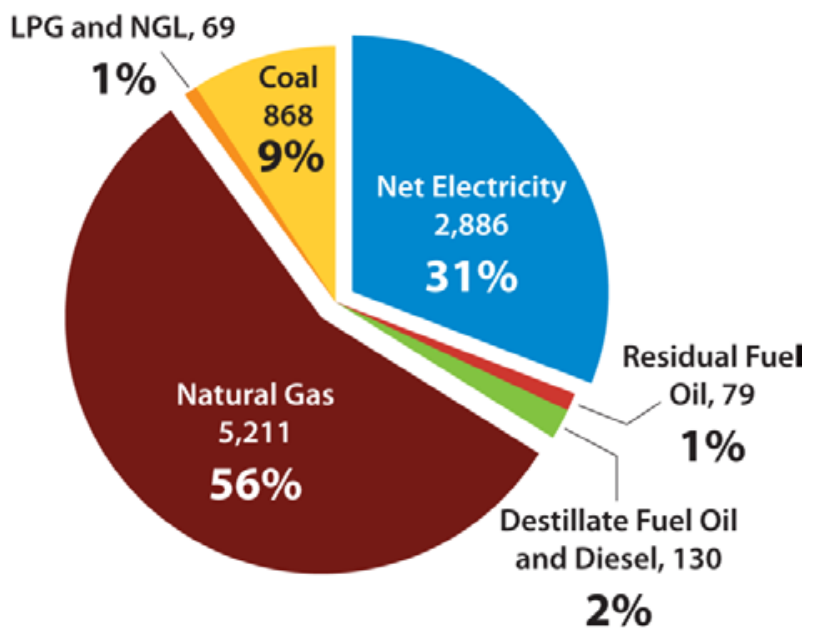

Figure 11. MECS 2010 energy end use by percentage and quantity (TBtu/yr) ${ }^{64}$

The MECS 2010 data for industrial energy consumption can be further broken down into direct and indirect uses, as shown in Figure 12. Direct use refers to heat applied to an industrial process via combustion flue gas or electric heaters, while indirect use refers to energy used to heat an intermediary fluid, most commonly water/steam. "Nonprocess use" is consumption occurring onsite, but not associated with industrial processes. This categorization shows that natural gas is the preferred energy source for steam generation, while natural gas and electricity are used almost equally for direct heating. The full table containing the end-use categories and the 2010 fuel consumption for electricity, coal, and natural gas is given in Appendix B.

\section{MECS 2010 Energy Consumption by End Use Category}

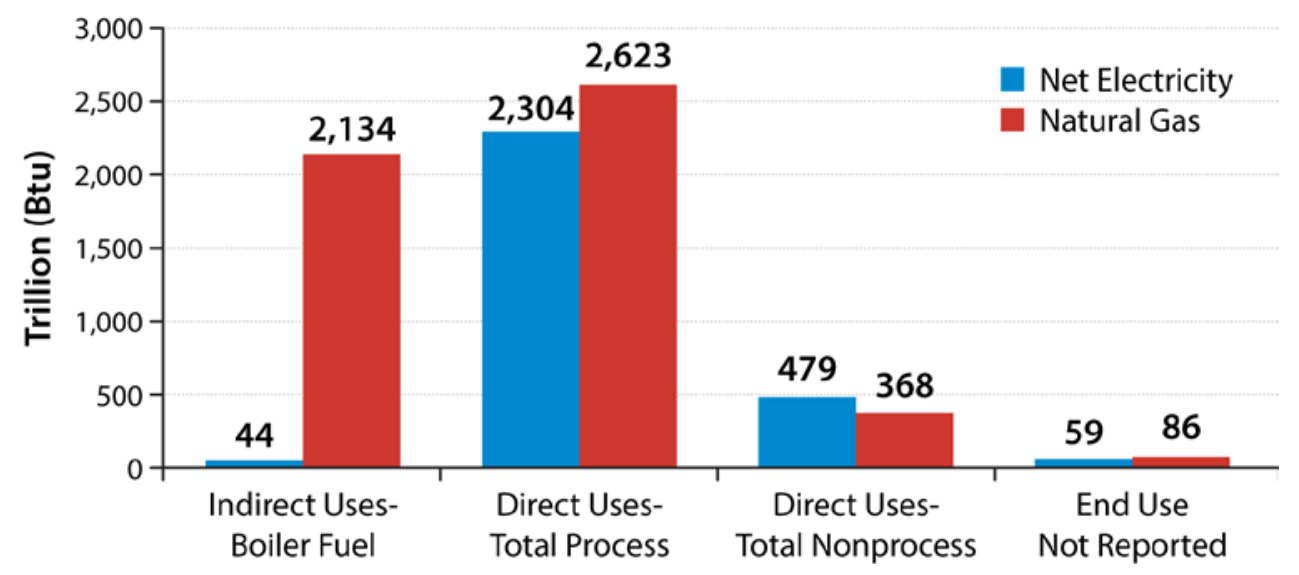

Figure 12. Energy consumption within the MECS industries by end-use category as of $2010^{65}$

It has been shown that fuel, especially natural gas, is a significant driver for the production of process heat, either through steam generation or direct heating. The data indicate that natural gas replacement is the biggest opportunity for SIPH. Situations where electricity can be offset will be rare, although they may present favorable economics. The next section explores gas consumption within specific industrial sectors. 


\subsection{U.S. Industrial Consumption of Natural Gas for Process Heat}

In the United States, the industrial and manufacturing sectors are the largest consumers of natural gas and electricity, specifically for process heat, either directly or indirectly through steam production via a conventional boiler. Several studies have quantified process heat consumption in industries across the United States. ${ }^{66}$ Figure 13 highlights the consumption of natural gas in the MECS industries and the portion of that consumption used for direct process heating and conventional boiler use.

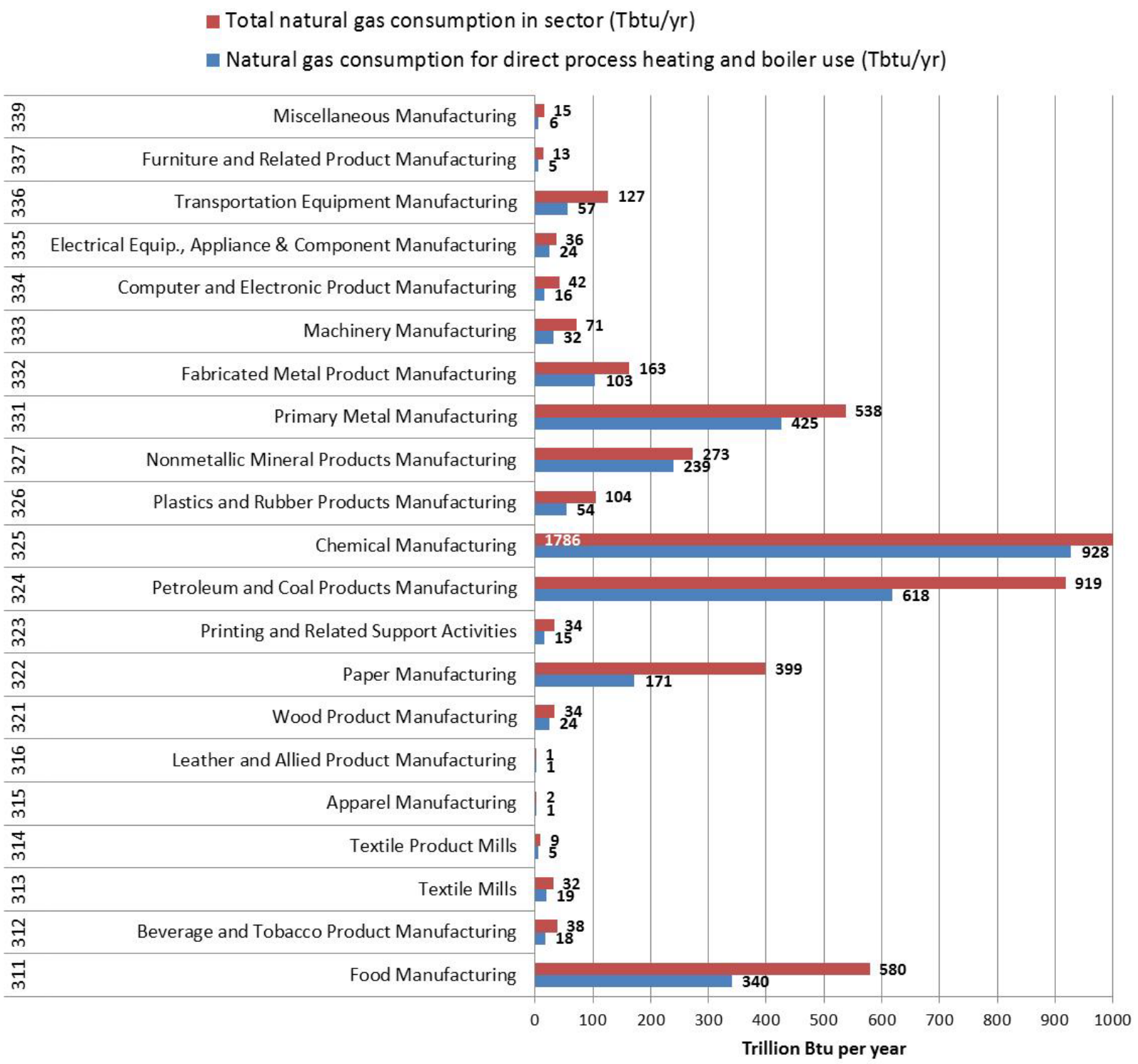

Figure 13. Total U.S. consumption of natural gas (NG) by MECS sector and natural gas used for direct process heating and conventional boiler use. ${ }^{67}$

From Figure 13, the sectors with the highest use of natural gas for direct process heating and conventional boiler include: chemical manufacturing, petroleum \& coal products, primary metals, and food manufacturing. However, total consumption is not the only consideration when 
exploring opportunities for SIPH. We also seek opportunities that align with solar collector capabilities.

A 2011 study by Cornell University identified five MECS subsectors that heavily utilize steam, focusing on steam temperature less than $260^{\circ} \mathrm{C}$. ${ }^{68}$ This temperature regime aligns well with target applications for concentrating solar collectors. The industrial sectors included food, paper, petroleum and coal, chemicals, and primary metals - consistent with major users of natural gas (Figure 13). The steam energy temperature distribution is shown in Table 7 and Figure 14.

Table 7. MECS Sectors with the greatest steam use at less than $260^{\circ} \mathrm{C}^{69}$

\begin{tabular}{|c|c|c|c|c|c|}
\hline \multirow[b]{2}{*}{$\begin{array}{c}\text { Temperature } \\
\text { Range }\left({ }^{\circ} \mathrm{C}\right)\end{array}$} & \multicolumn{5}{|c|}{ Steam Energy Temperature Distribution (\%) } \\
\hline & Food (311) & Paper (322) & $\begin{array}{l}\text { Petroleum and } \\
\text { Coal (324) }\end{array}$ & $\begin{array}{c}\text { Chemical } \\
(325)\end{array}$ & $\begin{array}{c}\text { Primary Metals } \\
\text { (331) }\end{array}$ \\
\hline$>260$ & - & - & - & 22 & 38 \\
\hline $240-260$ & - & - & - & 9 & \\
\hline $220-240$ & - & - & - & - & \\
\hline $200-220$ & 2 & - & 100 & - & \\
\hline $180-200$ & 6 & - & - & 9 & \\
\hline $160-180$ & 8 & 14 & - & 32 & 62 \\
\hline $140-160$ & - & 22 & - & 5 & \\
\hline $120-140$ & 11 & 64 & - & 23 & \\
\hline $100-120$ & 16 & - & - & - & \\
\hline $80-100$ & 16 & - & - & - & \\
\hline $60-80$ & 20 & - & - & - & \\
\hline $40-60$ & 21 & - & - & - & \\
\hline All Temps. & $100 \%$ & $100 \%$ & $100 \%$ & $100 \%$ & $100 \%$ \\
\hline$\leq 260$ & $100 \%$ & $100 \%$ & $100 \%$ & $78 \%$ & $62 \%$ \\
\hline
\end{tabular}

The total consumption in the range between $100^{\circ} \mathrm{C}$ and $260^{\circ} \mathrm{C}$ amounts to about 1.7 million $\mathrm{GWh}_{\text {th }}$. To put this in perspective, the $64 \mathrm{MWe}$ net Nevada Solar One parabolic trough plant produces about $350 \mathrm{GWh}_{\text {th }}$ per year, so the thermal energy potential depicted in Figure 14 represents the equivalent of about 4,800 such plants if all the sites were suitable for SIPH. All the sectors listed in Figure 14 utilize steam in temperature ranges suitable for solar generation; however, the food industry may consider the use of solar energy in their processes to be particularly appealing. As noted previously, the food sector has been the application of choice for many international SIPH plants. 


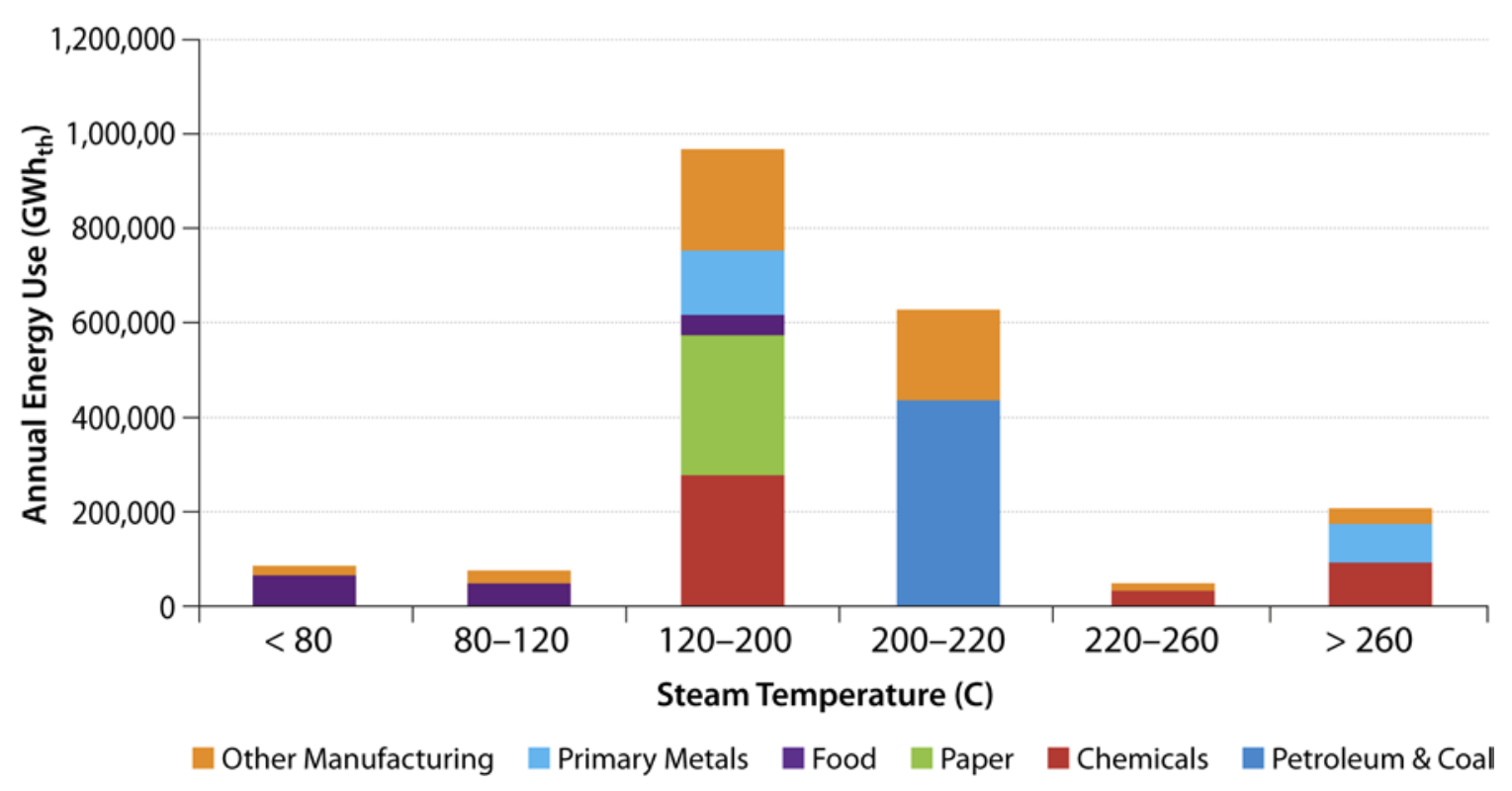

Figure 14. IPH annual energy use for steam generation for the industries utilizing the greatest amount of natural gas ${ }^{70}$

Comparing the data in Figure 14 and Table 2, it appears that the temperature range from about 120 to $220^{\circ} \mathrm{C}$ is of particular interest. This temperature range is characterized by the requirement to use concentrating optics, the ability to easily use water/steam as the HTF, flexibility in the selection of receiver tube vacuum insulation, and high IPH demand. Accordingly, the temperature range of $120^{\circ} \mathrm{C}$ to $220^{\circ} \mathrm{C}$ is viewed as an excellent target for concentrating solar collector deployment for SIPH.

Table 8 sums the consumption of natural gas that is used for direct process heating and conventional boiler use in the five industries that use the greatest amount of natural gas in these applications. Table 8 excludes the estimated fraction of natural gas consumption in chemicals and primary metals sectors that is at temperatures greater than $260^{\circ} \mathrm{C}$. The table highlights the maximum thermal energy demand in the subsector where natural gas could be replaced by SIPH for process heating requirements.

Table 8. U.S. natural gas consumption for direct process heating and conventional boiler use in high-use industry sectors ${ }^{71}$

\begin{tabular}{|c|l|c|c|}
\hline \multicolumn{2}{|l|}{} & \multicolumn{2}{c|}{ Natural Gas Consumed per Year } \\
\hline MECS Code & MECS subsector & Trillion Btu & $\mathbf{G W h}_{\text {th }}$ \\
\hline 311 & Food & 339 & 99,400 \\
\hline 322 & Paper & 170 & 49,800 \\
\hline 324 & Petroleum and Coal Products & 618 & 181,000 \\
\hline 325 & Chemical & 722 & 212,000 \\
\hline 331 & Primary Metals & 289 & 84,700 \\
\hline
\end{tabular}


This overall picture of the United States indicates that diverse industries heavily utilize natural gas for steam production and direct process heating. It has been estimated (Table 8) that the five industries in the United States that utilize the greatest amount of gas in these applications represent a thermal energy demand of approximately $627 \mathrm{TWh}_{\mathrm{th}} / \mathrm{yr}$. This demand is spread out, and requires further breakdown at the state level to highlight potential for SIPH. Subsequently, California is chosen for closer examination due to its high DNI resource, high natural gas use within these steam demanding industries, and the California Solar Initiative-Thermal (CSI-T) incentive that promotes SIPH.

\subsection{California Industrial Natural Gas Consumption}

The seven southwestern states of interest for this study account for approximately $35 \%$ of the 2013 total U.S. consumption of natural gas. ${ }^{72}$ Nationally, California ranks third in industrial gas usage behind Texas and Louisiana. ${ }^{73}$ When the sectors of residential, commercial, industrial, transport, and electricity generation are considered, California's 2013 consumption made up approximately $9.2 \%$ of the total U.S. consumption. The breakdown of the natural gas consumption by each sector identified in the 'State Energy Data 2013' is highlighted in Table 9, which shows nearly 34\% (854 TBtu/yr) of the natural gas consumption in California was for industrial use. $^{74}$

Table 9. Natural gas consumption (TBtu/yr) for California by use sector (as of 2013)

\begin{tabular}{|r|r|r|r|r|r|}
\hline Residential & Commercial & Industrial & Transport & $\begin{array}{r}\text { Electric Power } \\
\text { Generation }\end{array}$ & Total \\
\hline 496 & 263 & 854 & 28 & 851 & 2492 \\
\hline $20 \%$ & $11 \%$ & $34 \%$ & $1 \%$ & $34 \%$ & $100 \%$ \\
\hline
\end{tabular}

Previous market characterization studies for California have determined the breakdown and end use of natural gas and electricity within the industrial sector. ${ }^{76}$ The breakdown of natural gas usage indicates that approximately $86 \%$ is used for process heating or to produce steam (Figure 15 ) while only $11 \%$ of the electricity consumed in California industry was for process heating and a small, unspecified amount was for steam production (Figure 16). Hence, the primary conventional source that SIPH will compete with is natural gas.

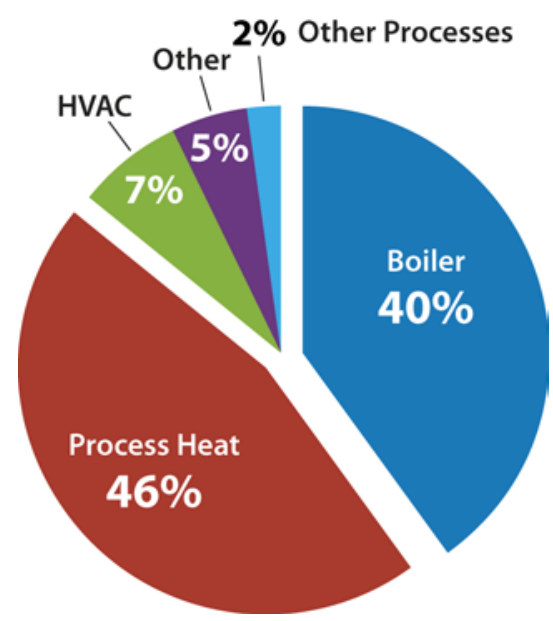

Figure 15. Industrial natural gas end use for California as of $2005^{77}$ 


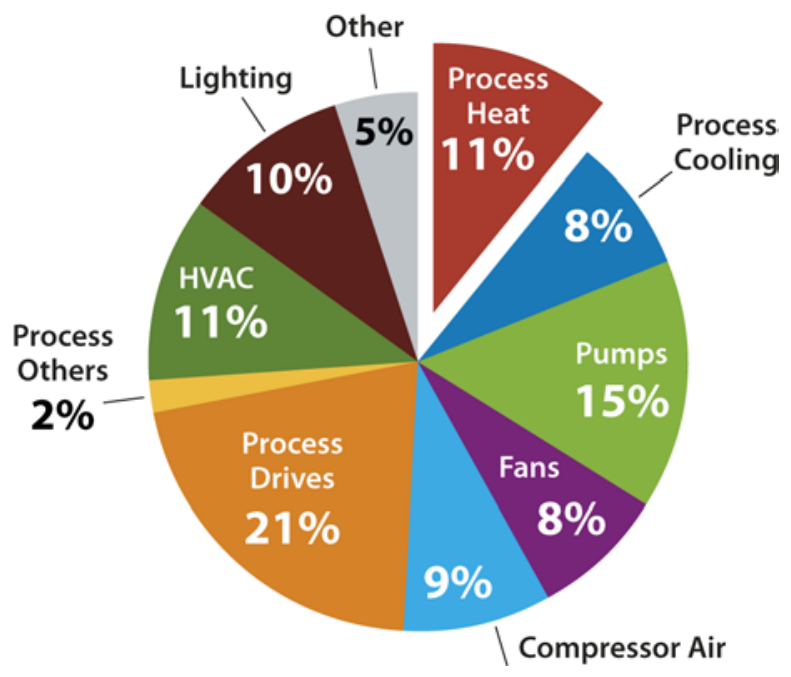

Figure 16. Industrial electrical end use for California as of $2005^{\mathbf{7 8}}$

A 2014 California Energy Commission (CEC) study listed natural gas consumption for the industries in California. ${ }^{79}$ The MECS data do not provide information at the state level; however, assuming the MECS 2010 U.S. data to be representative of the state level, the natural gas consumption specifically for direct process heating and conventional boiler use can be estimated for California. For example, in the MECS 2010 data, the food industry in the U.S. consumed approximately $59 \%$ of its total natural gas consumption for applications of direct process heating and conventional boiler use (Figure 13). Assuming this percentage holds for the food industry in California, we estimate that $10,200 \mathrm{GWh}_{\mathrm{th}} / \mathrm{yr}$ were consumed for direct process heating and conventional boiler use in the state. ${ }^{80}$ This methodology was continued across all MECS sectors to arrive at the data in Table 10.

Table 10 estimates the thermal energy used in California by the MECS industries identified as the biggest consumers of natural gas for direct process heating and conventional boiler use per Figure 13. California's food, paper, petroleum, chemical, and primary metals industries, demand about $48 \mathrm{TWh}_{\mathrm{th}} / \mathrm{yr}$ for direct process heating and steam production. For comparison, a 2012 study for Germany estimated the annual process heat demand at $134 \mathrm{TWh}_{\mathrm{th}} / \mathrm{yr}$ for temperatures less than $300^{\circ} \mathrm{C} .^{81}$ The CEC concluded industries in California such as food processing, chemicals, petroleum and primary metals manufacturing "represent prime areas of opportunity for reducing natural gas use". ${ }^{82}$

Table 10. Estimated natural gas consumption for direct process heating and boiler use in California for select MECS industries

\begin{tabular}{|l|l|c|}
\hline NAICS Code & MECS sector & $\begin{array}{c}\text { Natural Gas Consumption for } \\
\text { Process Heating (GWh }\end{array}$ /hr) \\
\hline 311 & Food Manufacturing & 10,200 \\
\hline 322 & Paper Manufacturing & 1,244 \\
\hline 324 & Petroleum and Coal Products Manufacturing & 31,211 \\
\hline 325 & Chemical manufacturing & 3,526 \\
\hline 331 & Primary Metal Manufacturing & 2,134 \\
\hline
\end{tabular}


Within the food processing industry in California, heat recovery measures such as the preheating of air and water for food processing, the pasteurization of dairy products, and canned vegetables have been identified as opportunities for significant natural gas reductions. ${ }^{83}$ The CEC estimated conservatively that a $1 \%$ annual reduction in the energy consumption from natural gas within the food industry could be equivalent to saving the food processing industry in California $\$ 3.4 \mathrm{M} /$ year, based on a 2012 gas price of $\$ 5.7 / \mathrm{MMBtu}$, with environmental benefits of 31,800 metric tons of $\mathrm{CO}_{2}$ saved annually. ${ }^{84}$

\subsection{Natural Gas Prices for Industry Across the U.S. Southwest}

Figure 17 illustrates the annual industrial natural gas price for the southwestern U.S. states from 2009 to 2014. The U.S. industrial average gas price is also shown. Over the period, Texas has had the lowest industrial gas prices within the Southwest region. Over the same period, California has had relatively high industrial natural gas prices, and exceeded the U.S. average by approximately \$2.4/MMBtu. It should be noted that discussions with SIPH developers in California indicate that industrial sites and customers often have price contracts that vary greatly from reported industrial gas prices. Thus, site-specific factors must be considered when assessing specific opportunities. Importantly for this discussion, in the last three years (2012-2014), California has had steady increases in industrial gas prices and is now near the top of U.S. industrial natural gas prices.

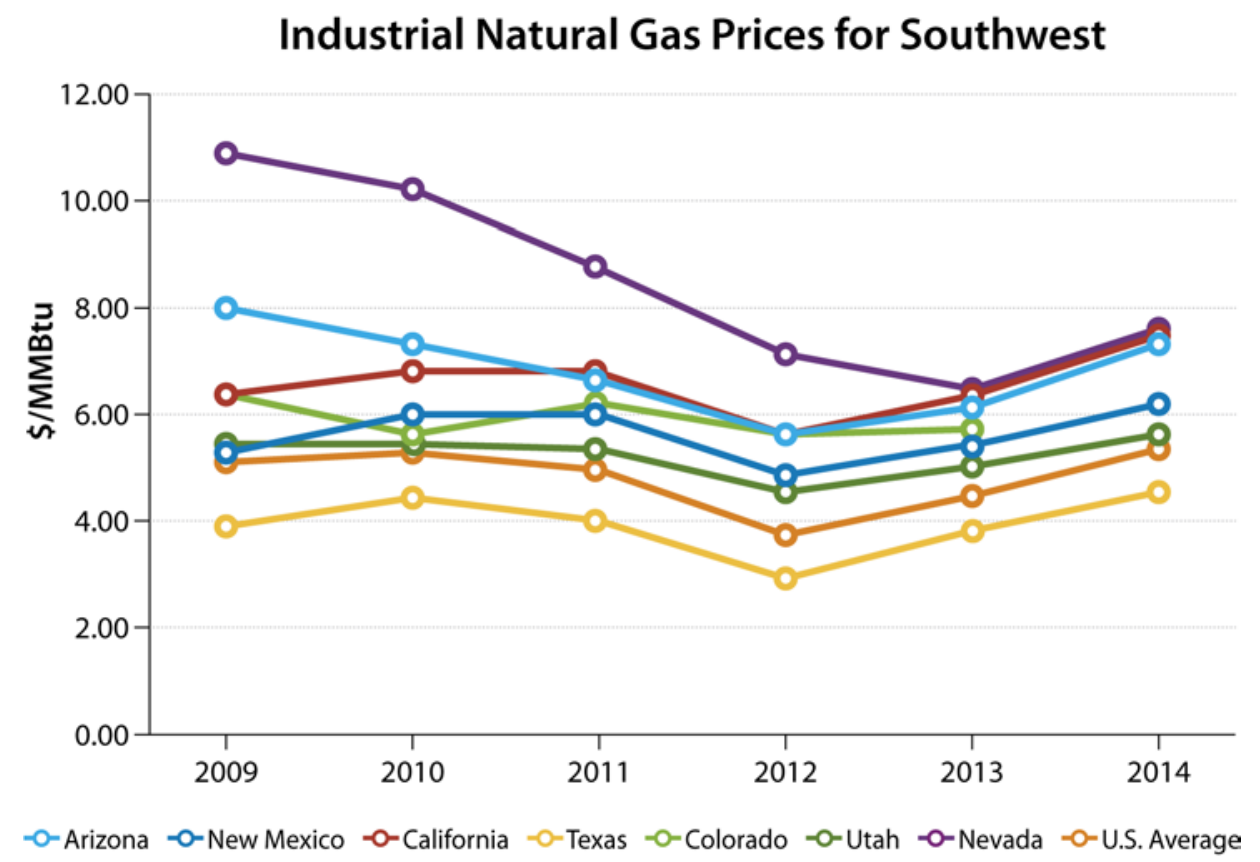

Figure 17. Natural gas prices for industry for the southwestern United States (2009 to 2014)

As illustrated in earlier sections, natural gas consumption by industries in California is considerable and as such, any rises in industrial natural gas price will have a significant economic impact for companies and industrial units who have high natural gas consumption for process heat requirements. This may have cost California food processors some $\$ 411 \mathrm{M}$, based on natural gas consumed in $2011 .^{86}$ The economic impact on companies and industries that can save on the purchase of natural gas (e.g. through greater efficiency or the integration of SIPH to 
provide process heat) is significant. In solar-rich areas like the Southwest, SIPH offers the potential to provide process heat, and could displace the use of natural gas, which can decrease the operating costs of industrial companies and bring down the carbon emissions from natural gas combustion.

\subsection{Southwestern U.S. DNI and Solar-Thermal Energy Potential}

This study creates an initial outlook for the potential of SIPH in the southwest, covering the states of California, Nevada, Utah, Colorado, Texas, New Mexico, and Arizona. As shown in Figure 18, this region contains the highest annual DNI in the United States. Focusing on these seven states does not imply they are the only areas suitable for SIPH, but that they could offer the best initial entry point for the technology. The temperature and steam demands for process heat in most industries are readily achievable by existing solar-thermal collectors; thus, the applicability of SIPH is unlikely to be limited by demand.

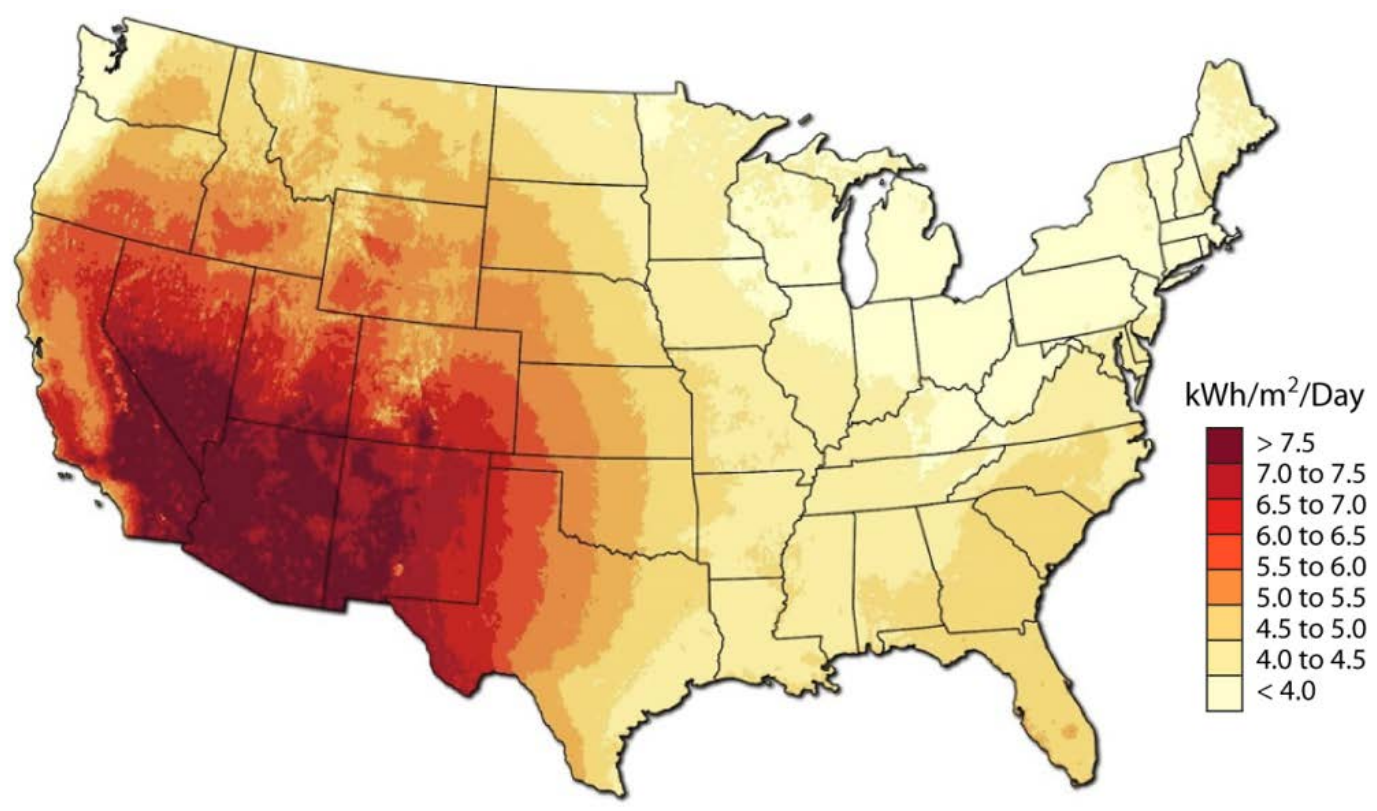

Figure 18. U.S. annual average DNI map (data from 1998 to 2009) ${ }^{87}$

IPH demands have been met with solar-thermal systems even in places like Canada and Germany, where the average DNI is lower than in the Southwest. For example, in Québec, Canada, Rackham Technologies has set up several plants using PTCs that provide process heat and steam for industries such as food and paper. ${ }^{88}$ The DNI in Québec and most parts of Germany is less than $3.5 \mathrm{kWh} / \mathrm{m}^{2} /$ day, which is significantly less than the $5.0 \mathrm{kWh} / \mathrm{m}^{2} /$ day limitation used for this study.

The DNI resource in Figure 18 shows only the raw resource potential. The technical thermal energy potential has been defined as "the achievable energy generation of a particular technology given system performance, topographic limitations, environmental and land-use constraints," according to a prior NREL study that explored the potential for electricity generation in the Southwest by CSP technology. ${ }^{89}$ The constraints for CSP electricity generation applied in that study included: 
- Average DNI taken over the period 1998 - 2005 at a 10-km horizontal spatial resolution, with DNI greater than $5 \mathrm{kWh} / \mathrm{m}^{2} /$ day required for consideration ${ }^{90}$

- Dry-cooled PTC power plants with six hours of thermal storage at a solar multiple of two

- Land with slope greater than 3\% excluded.

One of the key assumptions utilized in the prior NREL analysis was that contiguous land area of greater than or equal to $1 \mathrm{~km}^{2}$ was required for consideration. ${ }^{91}$ While an area limit of greater than one square kilometer ( 247 acres) is reasonable for electricity-generating CSP plants, this is not the case for smaller SIPH plants. For example, the Modesto SIPH plant, which is one of the larger SIPH plants in the world, occupies only about 4.5 acres. ${ }^{92}$ That is, nearly 55 Modesto SIPH plants could fit into the $1 \mathrm{~km}^{2}$ constraint. As will be seen, even with this constraint, California has an enormous technical thermal energy potential.

This study assumes SIPH systems are deployed on the ground. As highlighted earlier in this study, adjacent land area or roof area (e.g., in the case of LFs and roof-mounted PTCs ${ }^{93}$ ) can be utilized for the solar field to provide the heat and steam to an industrial plant. A refinement for the future would include roof area into the theoretical potential. As in the German study for solar-thermal potential, ${ }^{94}$ satellite and GIS data can be used to understand available roof space that could be utilized if adjacent land was unavailable. For industrial players in the Southwest, adjacent land may not be a significant limiting factor due to the vast availability of land. However, inclusion of roof area could be valuable for future studies, particularly in densely developed areas.

NREL's 2012 solar resource study ${ }^{95}$ was used as the basis for estimating the technical thermal energy potential for SIPH, subject to several modifications. A commercial PTC system was still assumed, but without storage and with a solar multiple of 1.4. For determining the heat generation potential, the formula below was used:

$$
\begin{aligned}
& \text { State } \mathrm{MWh}_{\text {th }}=\text { State } \sum\left[\text { Available land }\left(\mathrm{km}^{2}\right) \times 139.3 \mathrm{MW} \text { th } / \mathrm{km}^{2}\right. \\
& \quad \times \text { Capacity Factor }(\% \text { for DNI class }) \times 8760 \mathrm{hrs} \text { per year }]
\end{aligned}
$$

The thermal power density of $139.3 \mathrm{MW}_{\mathrm{th}} / \mathrm{km}^{2}$ was derived from the electric power density used in the prior NREL study (of $49.4 \mathrm{MW}_{\mathrm{e}} / \mathrm{km}^{2}$ ) divided by the thermo-electric power cycle efficiency of that study (35.5\%). ${ }^{96}$ This energy density was debited based on the quality of the DNI resource for the land area in question using an estimate of capacity factor. Table 11 lists the capacity factors allocated for thermal generation by DNI resource class. 
Table 11. Thermal Power Density and Capacity Factor by DNI Class

\begin{tabular}{|c|c|c|}
\hline \multicolumn{3}{|c|}{$\begin{array}{l}\text { Trough, without Storage, Solar Multiple = 1.4. Thermal powe } \\
\text { density }=139.3 \mathrm{MW}_{\mathrm{th}} / \mathrm{km}^{2}\end{array}$} \\
\hline DNI Class & $\begin{array}{l}\text { DNI resource } \\
\left(\mathrm{kWh} / \mathrm{m}^{2} / \text { day }\right)\end{array}$ & Capacity Factor \\
\hline 1 & $5-6.25$ & 0.199 \\
\hline 2 & $6.25-7.25$ & 0.248 \\
\hline 3 & $7.25-7.5$ & 0.277 \\
\hline 4 & $7.5-7.75$ & 0.284 \\
\hline 5 & $\geq 7.75$ & 0.295 \\
\hline
\end{tabular}

Utilizing this method, the technical solar-thermal energy generation potential for California using PTCs has been estimated in the available areas. Figure 19 shows the annual thermal energy generation potential in California based on the constraints listed above. The annual thermal energy generation potential per county is given in Appendix C.

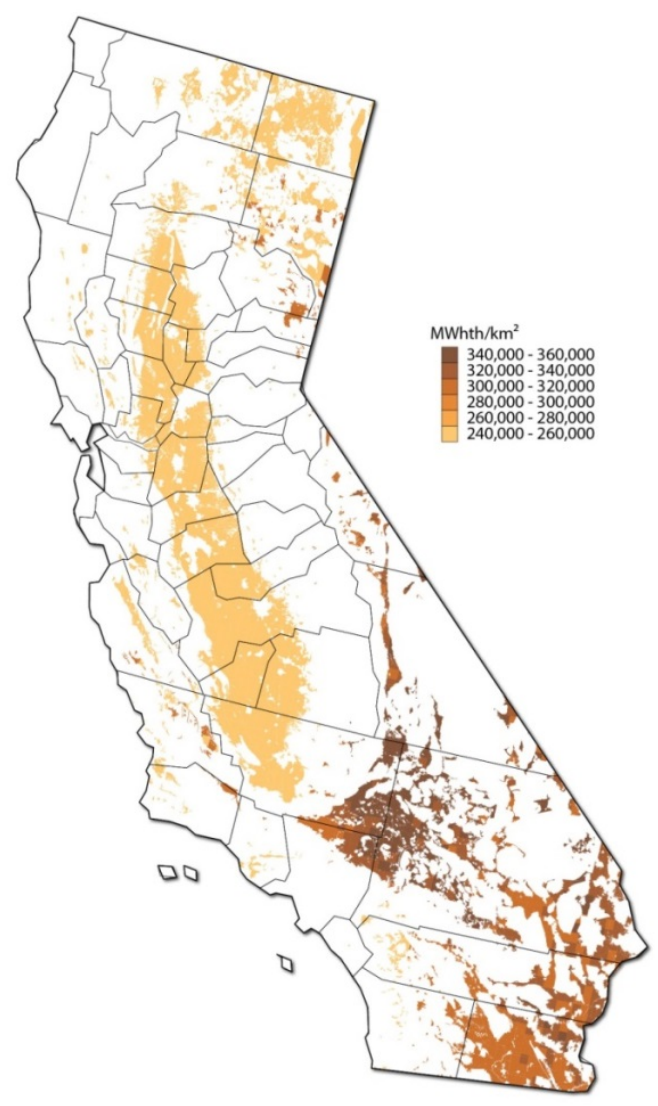

Figure 19. Solar-thermal energy potential $\left(\mathrm{MWh}_{\mathrm{th}} / \mathrm{km}^{2}\right)$ for California based on DNI and land area constraints

The technical thermal energy potential for PTCs was estimated using NREL's System Advisor Model (SAM). The estimated value of 22,887 $\mathrm{TWh}_{\mathrm{th}} / \mathrm{yr}$ is several orders of magnitude greater than the $48 \mathrm{TWh}_{\mathrm{th}} / \mathrm{yr}$ demand for the selected Californian industries. Figure 19 highlights that the 
most thermally rich areas of California are in the south, including San Bernardino, Kern, Riverside, and Imperial counties, although the Central Valley also has good solar resource.

\subsection{Locations of California Industries Using IPH}

An objective for this report is to tie specific industries known for high use of IPH to their local solar-thermal energy potential. For this study, the food industry and sample sub-industries in California were considered prime candidates. These include the MECS sub-industries of animal food processing, breweries, and dairy products. To highlight that the thermal demand of these industries can be theoretically met with SIPH potential found for California, maps overlaying the location of the industries in California and the estimated thermal energy potential are shown. Figure 20 shows the locations of known animal food processing plants, breweries, and dairy products along with the technical thermal energy potential. Each figure is shown separately in Appendix C.

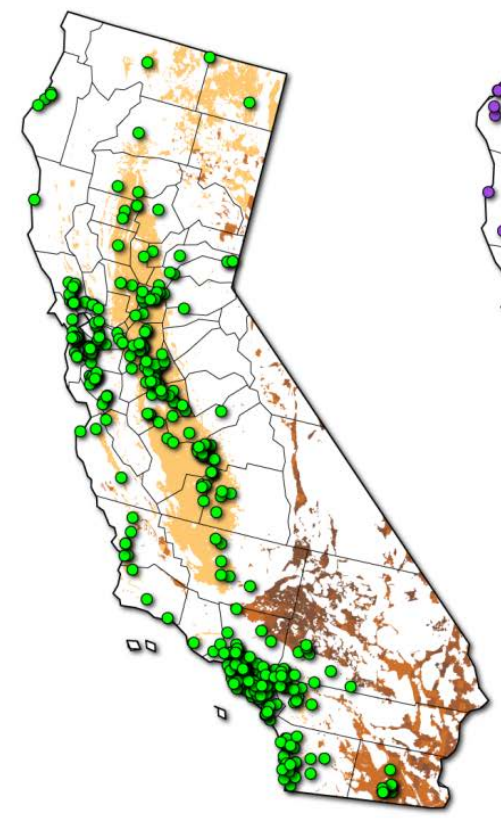

Food Processing:

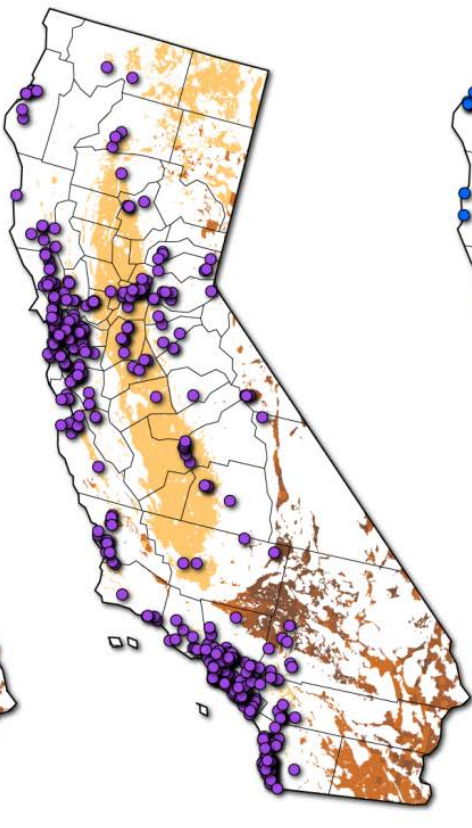

- Breweries

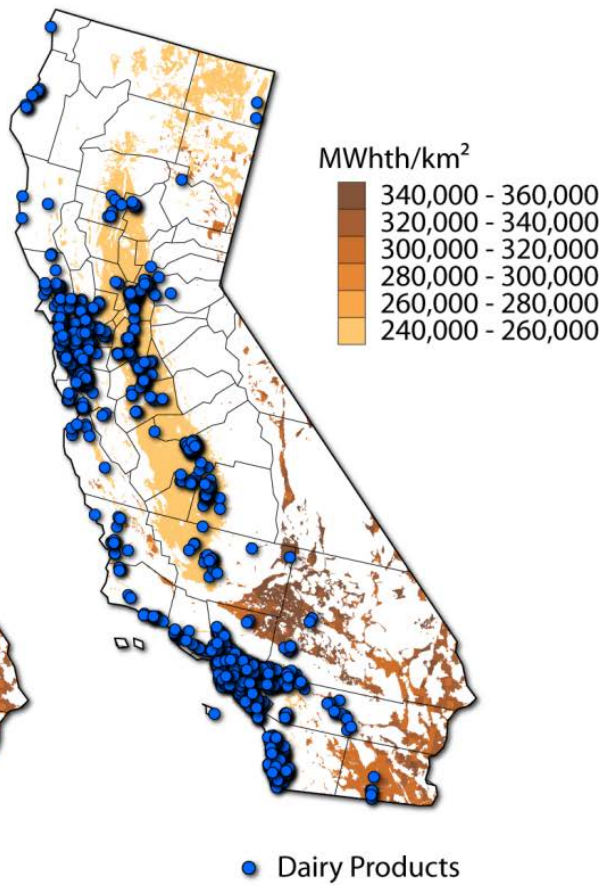

- Dairy Products

Figure 20. Locations of animal-food processing, breweries, and dairy products plants across California along with annual solar-thermal energy potential

The thermal energy potential for PTCs in California's Central Valley, while of a lower resource level than the state's top solar areas, exhibits good proximity with industries that need steam. Most of the locations of animal food processing, breweries, and dairy industries industrial sites that use steam are far from the best solar resources in southern California. This is not surprising as the best solar resource regions correspond with California's deserts. However, as can be seen in Figure 20, significant concentrations of these food related subindustry manufacturers are clustered throughout the Central Valley of California, where resource has been identified as good. There are fewer sites in the exceptionally sunny south that could benefit from SIPH; however, these facilities might make excellent case studies for further investigation. The Central Valley is appropriate for targeting the numerous industries located in the valley that could benefit from SIPH. 
Unlike electricity, which can be transmitted hundreds of miles or more, heat and steam must be generated fairly close to the location of use. The city of Fresno has been chosen to highlight the proximity of the solar-thermal energy supply to the potential industrial users in the Central Valley. Fresno was a good example where the CSP IPH potential was found to be adjacent to clusters of Food processors, on what was identified as available land. This land would allow a CSP IPH solar field to be built. Areas within California will need to be investigated to determine the specific areas and actual land availabilty at the industrial site. Figure 21 shows the locations of the animal processing, breweries, dairy product manufacturing, and processed fruit and vegetable producers in and near Fresno, overlaid with the solar-thermal energy supply. The developed city areas and other exclusion zones are shown in white.

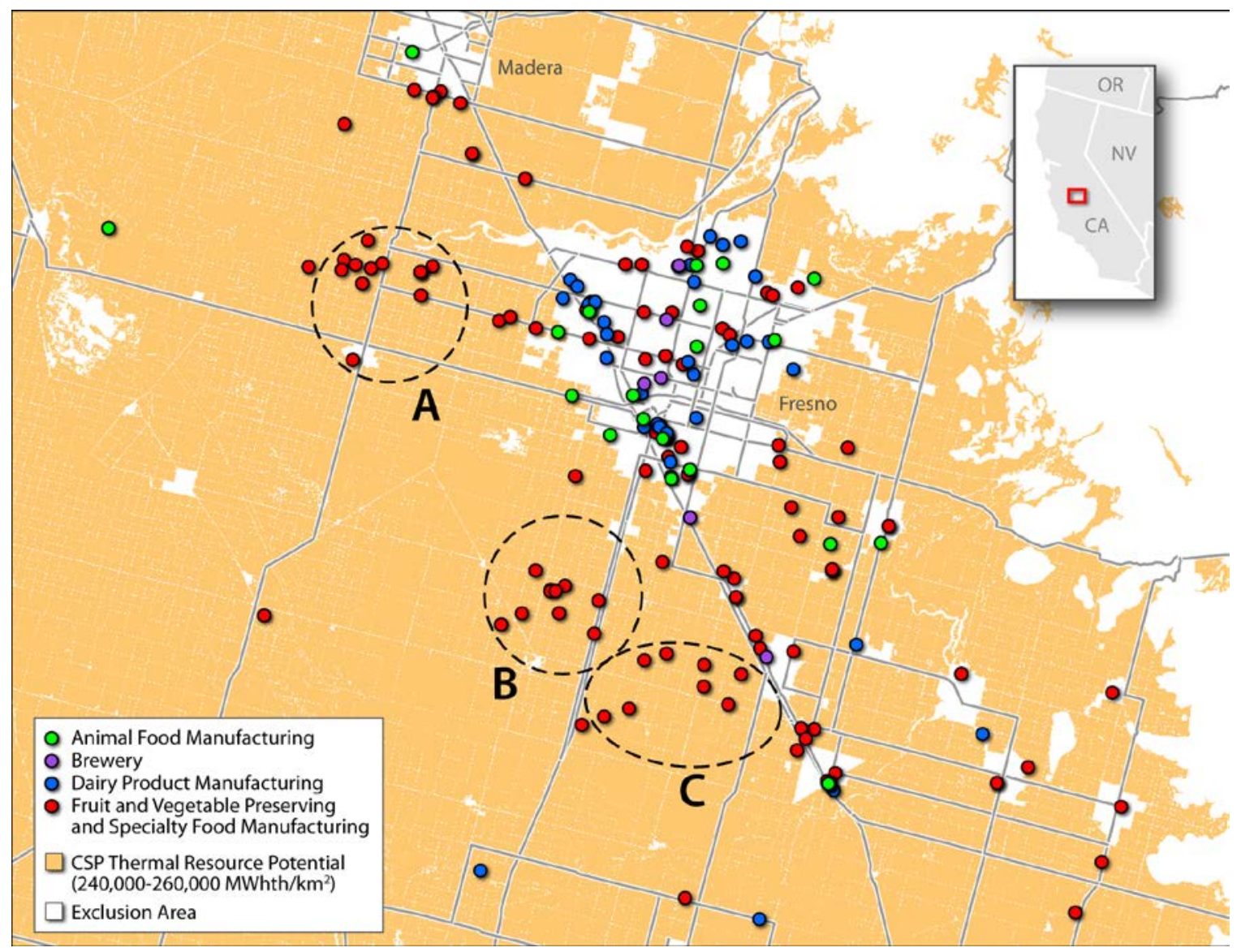

Figure 21. Close up of Fresno showing the solar-thermal generation potential and potential user industries

Clusters of multiple users near a potential SIPH plant site increases the likelihood of favorable economics. Furthermore, the $1 \mathrm{~km}^{2}$ siting constraint of the prior solar resource study is likely too restrictive for SIPH installations, and there may be sites within the city limits that could be developed for SIPH. As demonstrated in the figure, while the majority of the potential users are within the Fresno city limits, there are clusters of specific industries outside the city limits that could potentially benefit from SIPH plants. As can be seen, clusters A, B, and C of fruit and vegetable manufacturing plants potentially have available land for solar developers to install SIPH facilities and provide heat to augment steam production processes. This information would be elucidated in site-specific case studies. 


\subsection{IPH Collector Costs and LCOH}

With increasing interest in the potential of SIPH, several solar developers have sought to introduce or pursue PTCs and LFs for supply of thermal energy or steam. In 2014, NREL queried over a dozen collector manufacturers known to be in the SIPH market regarding the estimated price for their hardware. The data were requested with the understanding that specific companies would not be identified. Nine suppliers responded, with the results presented in Figure 22. The specified project assumptions given to the suppliers were:

- Site land area available was 20 ha (approx. $450 \mathrm{~m}$ by $450 \mathrm{~m}$, or 50 acres)

- Desired thermal product was saturated steam at $200^{\circ} \mathrm{C}$

- Desired thermal capacity was at least $10 \mathrm{MW}$

- Solar field hardware (collector, receiver, and drive system) prices were to be provided as Free on Board (FOB) at the manufacturing location.

As seen in Figure 22, the range of uninstalled collector costs quoted for the SIPH application was between $\$ 63-243 / \mathrm{m}^{2}$.

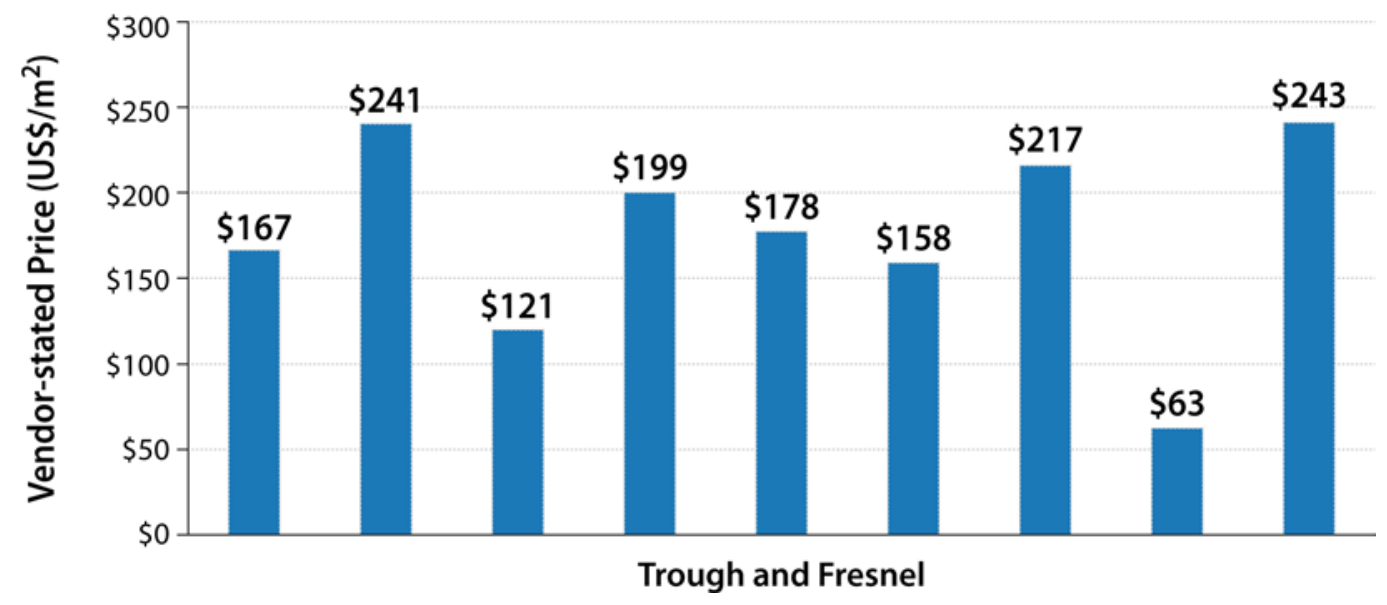

Figure 22. Quoted FOB uninstalled collector costs $\left(\$ / \mathrm{m}^{2}\right)$

NREL estimated shipping costs from the country of origin to the port of San Diego, California based on the number of 40-ft intermodal containers needed to ship the material and hardware. Trucking costs were added to a hypothetical inland site. Total shipping costs amounted to only about $\$ 1-2 / \mathrm{m}^{2}$. Lastly, NREL estimated the installation costs based on prior estimates for a large parabolic trough power plant. Solar field installation costs (foundation and pylons, field wiring, and assembly labor) were estimated using merit-shop labor rates for Arizona. ${ }^{97}$ This source is for large troughs, and several vendors report low installation costs due to their design, ${ }^{98}$ so a high and a low range were applied to installation costs. The high range was set by adjusting costs from 2009 to 2013 using Chemical Engineering Plant Cost Indices (CEPCI). ${ }^{99}$ The low range was taken to be $50 \%$ lower. Actual installed costs are expected to vary with system design and fall between these limits (i.e., within the hashed range of the bars in Figure 23). 


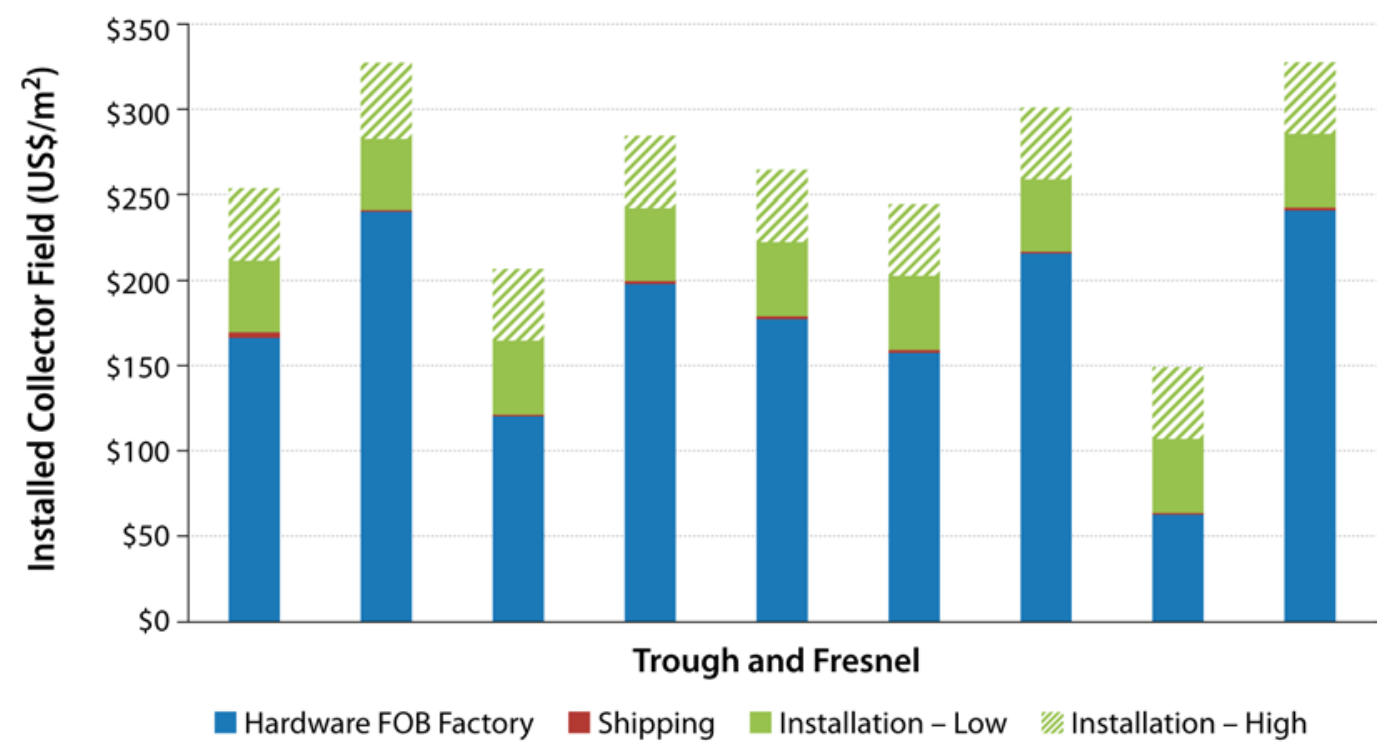

Figure 23. Estimated installed collector costs per $\mathrm{m}^{2}$ for a 20 -ha SIPH installation

Note: Aperture area that can be placed on such a site depends on the technology.

The $\mathrm{LCOH}$ is defined as a convenient metric for estimating lifetime cost of a solar collector system for process heat applications. $\mathrm{LCOH}$ is defined analogously to LCOE, which conventionally refers to electric energy. In its simplest form, $\mathrm{LCOH}$ is defined as:

$$
L C O H=\frac{(\text { Total installed project cost }) *(F C R)+(\text { Annual O\&M })}{\text { Annual thermal generation }}
$$

where the FCR is the fixed charge rate. The FCR depends on a range of financial parameters that can have a significant influence on $\mathrm{LCOH}$, and includes the weighted average cost of capital (WACC) and construction financing. NREL's SAM includes various ways of estimating LCOE. The latest release (SAM version 2015-06-30) includes a procedure for estimating and using the FCR method, which is used in this study. We list the WACC as well, as this may be a more familiar metric to many readers. More information on the approach is summarized in Appendix D.

The LCOH can be used to estimate whether solar collectors for process heat are competitive with alternative sources of thermal energy. Figure 24 illustrates the LCOH estimated for a range of solar resource and solar/project cost. The financial parameters used to estimate the FCR are taken as SAM's default values, with the exception of the construction period. Here we assume these smaller, simpler IPH systems are built in less than one year whereas SAM's default case is for large CSP plants that take approximately two to three years for construction. 


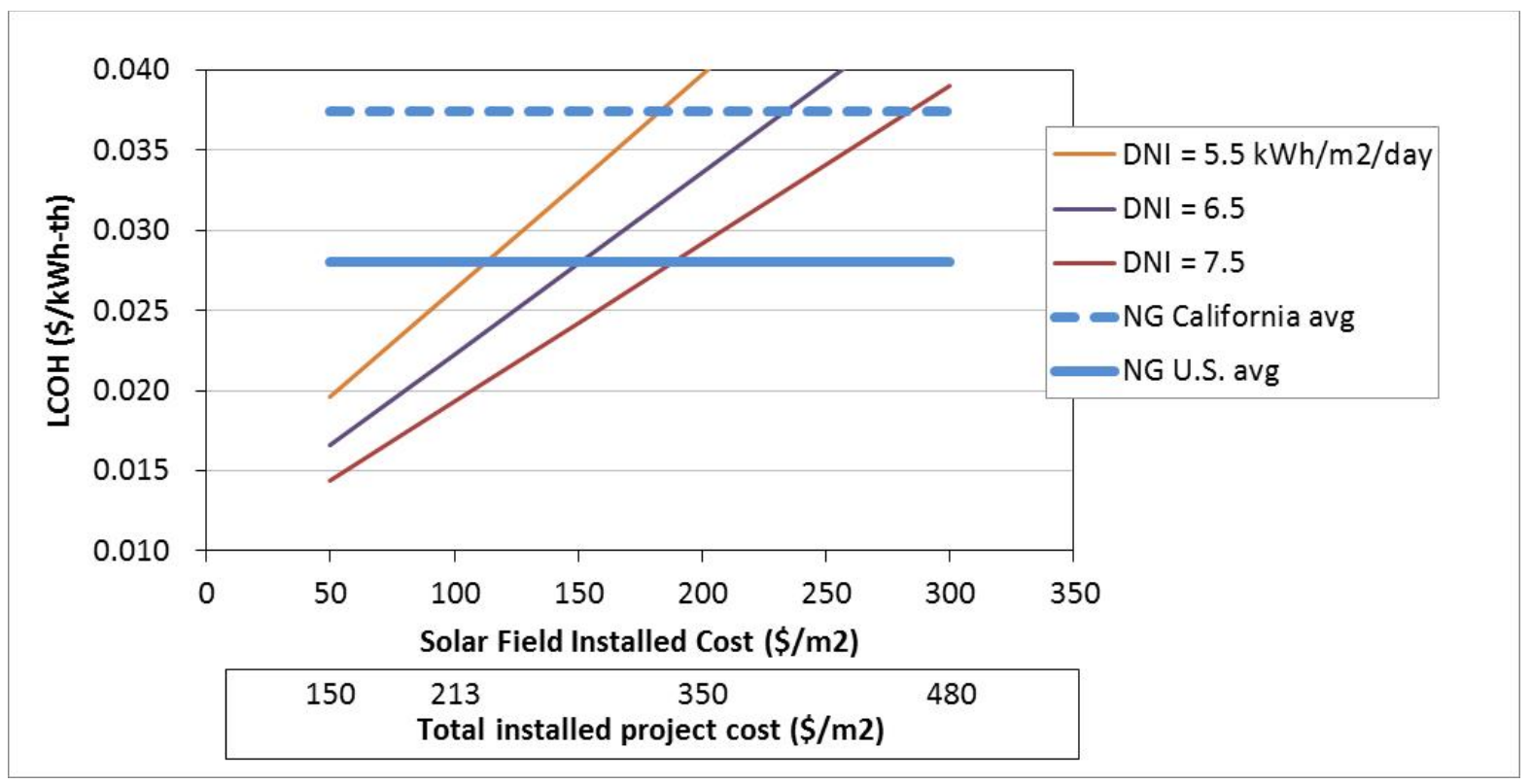

Figure 24. Estimated LCOH for different solar resource and solar field costs compared with two LCOHs from the use of natural gas at U.S. and Californian Industrial natural gas prices

Note: Natural gas prices from Figure 17, data from 2014. Total installed project cost includes solar field, site preparation, HTF system piping, HTF heat exchanger, and other project costs. Gas costs include $\$ 200 / \mathrm{kW}$ burner cost and $80 \%$ efficiency. Based on FCR $=0.101$ (WACC $=6.2 \%$ ), see Appendix D for more detail.

Based on Figure 23, a realistic value for the installed cost of a SIPH solar field is about $\$ 200 / \mathrm{m}^{2}$. As depicted in Figure 24, at that cost, solar-thermal energy is competitive with natural gas combustion for heat at its average California price of \$7.6/MMBtu, when the solar DNI is about $6.0 \mathrm{kWh} / \mathrm{m}^{2} /$ day or greater. However, the same solar field cost is not competitive with natural gas at its reported national average price of $\$ 5.4 / \mathrm{MMBtu}$, even at DNI equal to $7.5 \mathrm{kWh} / \mathrm{m}^{2} /$ day. The data suggest that economic SIPH applications can be found in California at existing solar hardware costs and market gas prices. However, project viability will be strongly dependent on the specific solar project costs - including any incentives - and the specific gas pricing contract in place. The deployment of a few successful cases would be expected to spur further utilization of SIPH with a concomitant decrease in project development costs.

\subsection{U.S. Incentives for SIPH}

Within the United States, many states have financial and tax incentives for SIPH, ${ }^{100}$ and California has more incentives for industrial solar-thermal systems than almost any other state. ${ }^{101}$ As of July 2014, California increased the available budget for commercial projects that utilize solar-thermal to displace natural gas through its CSI-T program. ${ }^{102}$ In the first stage of the program, industrial- or commercial-sized systems greater than $250 \mathrm{~kW}$ th can receive $\$ 10.10 /$ therm of displaced natural gas, up to a maximum of $\$ 800,000$ per site for up to four sites. The installer can receive a Performance Based Incentive (PBI) dependent on the amount of natural gas displaced due to the installation of a SIPH system. The PBI has rigorous thermal monitoring, to ensure that the incentive is given for the best performing systems. However, as of June 2015, no SIPH plant has been built to take advantage of this program. 
Discussions with solar developers have highlighted that several companies are endeavoring to establish commercial SIPH projects in California under the CSI-T. The urgency is that the program expires at the end of 2017. At good DNI sites, based on the current prices of natural gas, at least one developer of PTCs has quoted potential industrial customers a payback period of under three years based on the CSI-T incentive.

To understand the market and economic potential of SIPH, the financial incentives must also be factored in for future analysis. This report has not explored the detailed nature or different types of the state incentives for SIPH or how industries could best benefit from their implementation. Future analysis would be worthwhile for understanding which incentives and programs are most suited and for which SIPH size ranges. Further studies could also highlight the best states where the incentives foster the adoption of SIPH for displacement of fossil fuels.

\subsection{U.S. Case Studies for SIPH Plants}

As of March 2015, there were a total of 18 registered SIPH projects in the United States, all but two using flat-plate, solar-thermal collectors. ${ }^{103}$ Additionally, the authors know of PTC plants in the United States that are used for hot water are not listed in the SHIP database. For example, Abengoa Solar systems at federal prisons in Phoenix, Arizona and Lakewood, Colorado. As shown in Figure 25, the two listed PTC SIPH plants are the Frito Lay food processing plant in Modesto, California and the WaterFX desalination plant in Panoche County, California.
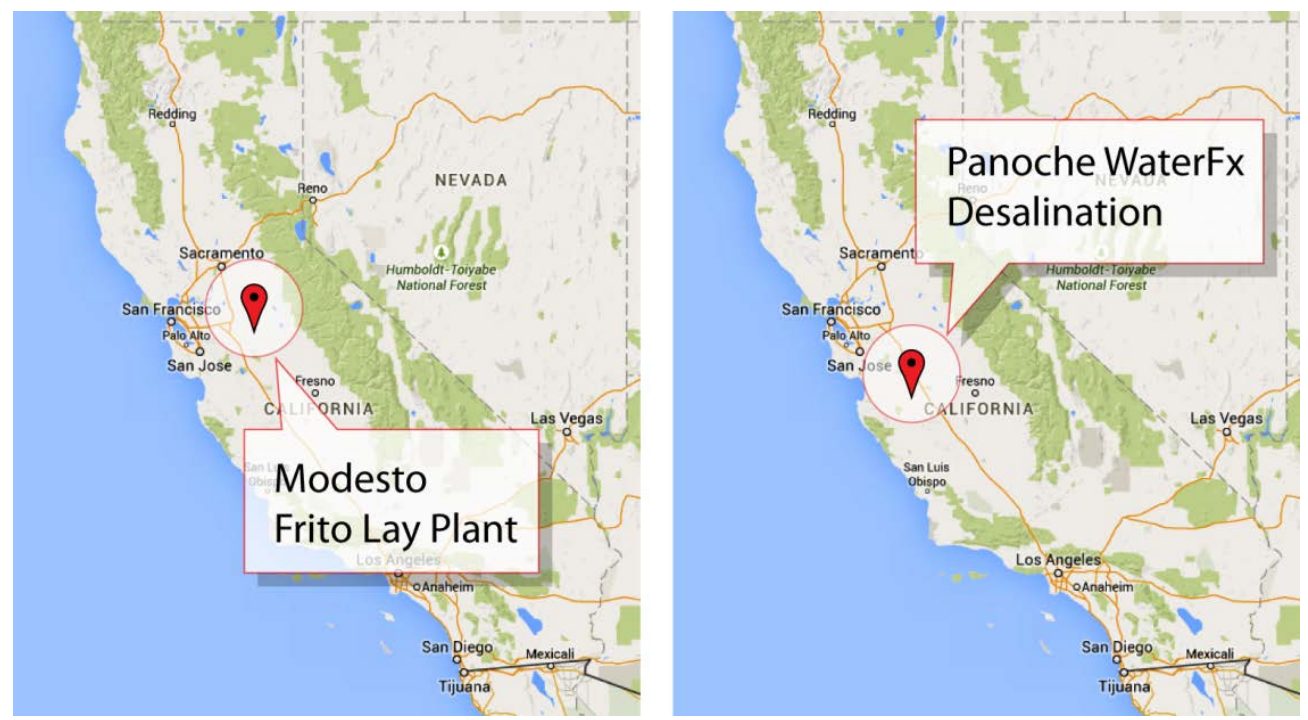

Figure 25. Modesto and Panoche SIPH plants as of Sept. 2014

\subsubsection{Modesto Frito Lay Food Processing Plant}

The Frito Lay plant in Modesto, California was engineered and built by Industrial Solar Technology, now part of Abengoa Solar, and started operation in 2008. The solar field has an installed net collector area of $5,387 \mathrm{~m}^{2}\left(57,969 \mathrm{ft}^{2}\right)$ and provides pressurized hot water exiting the solar field at $246^{\circ} \mathrm{C}$ for the heating of the oil used to fry potato chips. ${ }^{104}$ The PTCs used at the site can be seen in Figure 26 both at the noon and morning positions. 

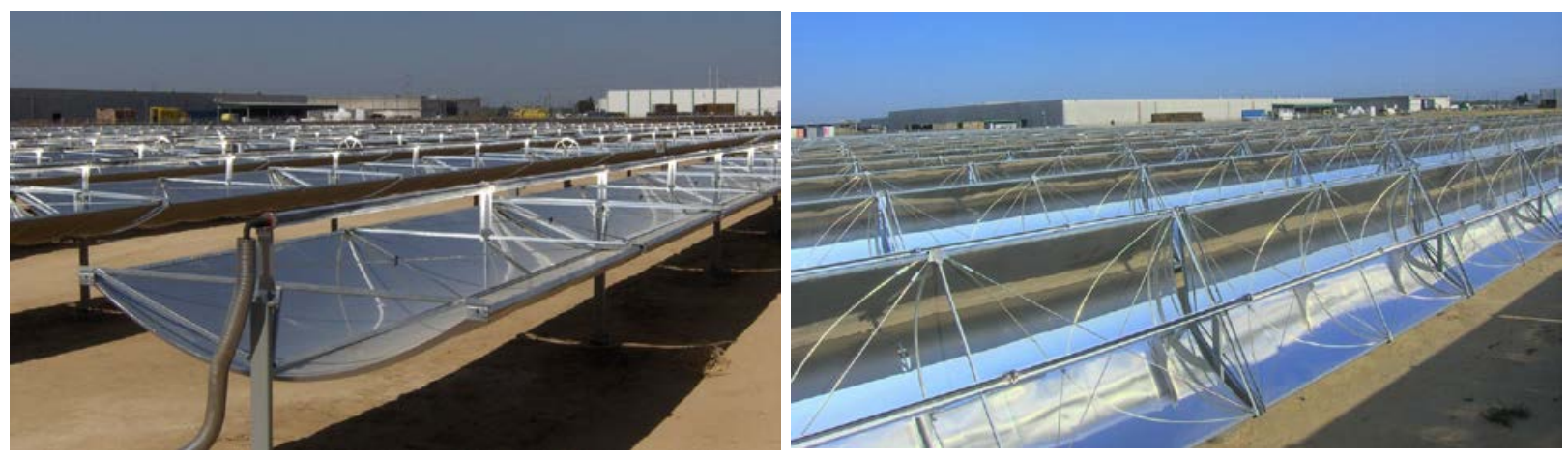

Figure 26. PTCs at the Frito Lay Modesto food processing plant ${ }^{105}$

The goal of the project was to reduce natural gas consumption in the plant, especially during summer peak days, by approximately $20 \%$ and to demonstrate that the trough technology was cost effective, safe, and a reliable source of thermal energy. ${ }^{106}$ Natural gas at the site is used by a conventional boiler to heat the oil used for the chip frying. Prior to the installation of the PTCs, the average yearly natural gas consumption was approximately 100 billion Btu/year. ${ }^{107}$ The NREL feasibility studies of the site indicated that approximately 14 billion Btu/year of thermal energy could be delivered from the solar field, leading to a 20 billion Btu/year displacement of natural gas. ${ }^{108}$

The troughs used in the project employ aluminum frame structures and silver-film reflective materials. The use of reflective film and aluminum, instead of glass and steel, significantly decreased the weight of the collectors. The full sized solar field consisted of 384 collector modules in strings of 24 . The final construction costs of the project were $\sim \$ 0.439 \mathrm{per}$ Btu/hr of thermal energy delivered, or $\$ 1,500 / \mathrm{kW}_{\text {th. }}{ }^{109}$ The reported installed cost was $\$ 3.95 \mathrm{M}$ or $\$ 733 / \mathrm{m}^{2}$, and the estimated payback period, based on the then-current natural gas price of $\$ 9 / \mathrm{MMBtu}$, was 7 to 10 years. ${ }^{110}$

As of 2010, the operation of the plant revealed that the natural gas displacement due to the solar integration was 12 billion Btu/year rather than the modeled and designed 20 billion Btu/year. ${ }^{111}$ The primary issues related to the lower solar-thermal output included: ${ }^{12}$

- Removal of the low-grade heat dump as part of the original design, which led to a decrease in the energy yield from the solar field

- An additional 1,000ft of distribution piping, which led to significant increases in the thermal energy lost from the solar field

- Local soiling impacts which were higher than predicted, reducing the solar-thermal output from the field by nearly $6 \%$

- Fewer hours of solar-thermal operation due to conditions at the site and a decreased energy utilization the solar field from $100 \%$ to $86 \%$.

Lesser natural gas savings at Modesto relative to the modeled simulations increased the payback period of the SIPH plant. This was exacerbated by lower-than-predicted gas prices in California, where since 2009, the annual average industrial price of natural gas has remained under \$7.5/MMBtu. ${ }^{113}$ 
Discussions with Abengoa Solar have indicated that as a first project, this was considered a success and the company has further plans to supply SIPH using the Model PT-1 trough. Reductions in the cost of this design and improvements in system modeling and operating experience suggest that the limitations listed above can be overcome with subsequent installations. Overall, the California industry and government are still keen on developing SIPH plants and has stated:

[I]nland areas of California represent a resource to the citizens which can be harvested to produce process heat used by many industries in the state and that it is a viable way of decreasing GHCs. ${ }^{114}$

\subsubsection{Desalination and California's Need for Water}

For the past several years, the western United States and California in particular have been experiencing severe drought. Figure 27 shows the U.S. Drought Monitor Map for June 9, 2015, and Figure 28 highlights how the region of extreme and exceptional drought has grown in the past year alone.

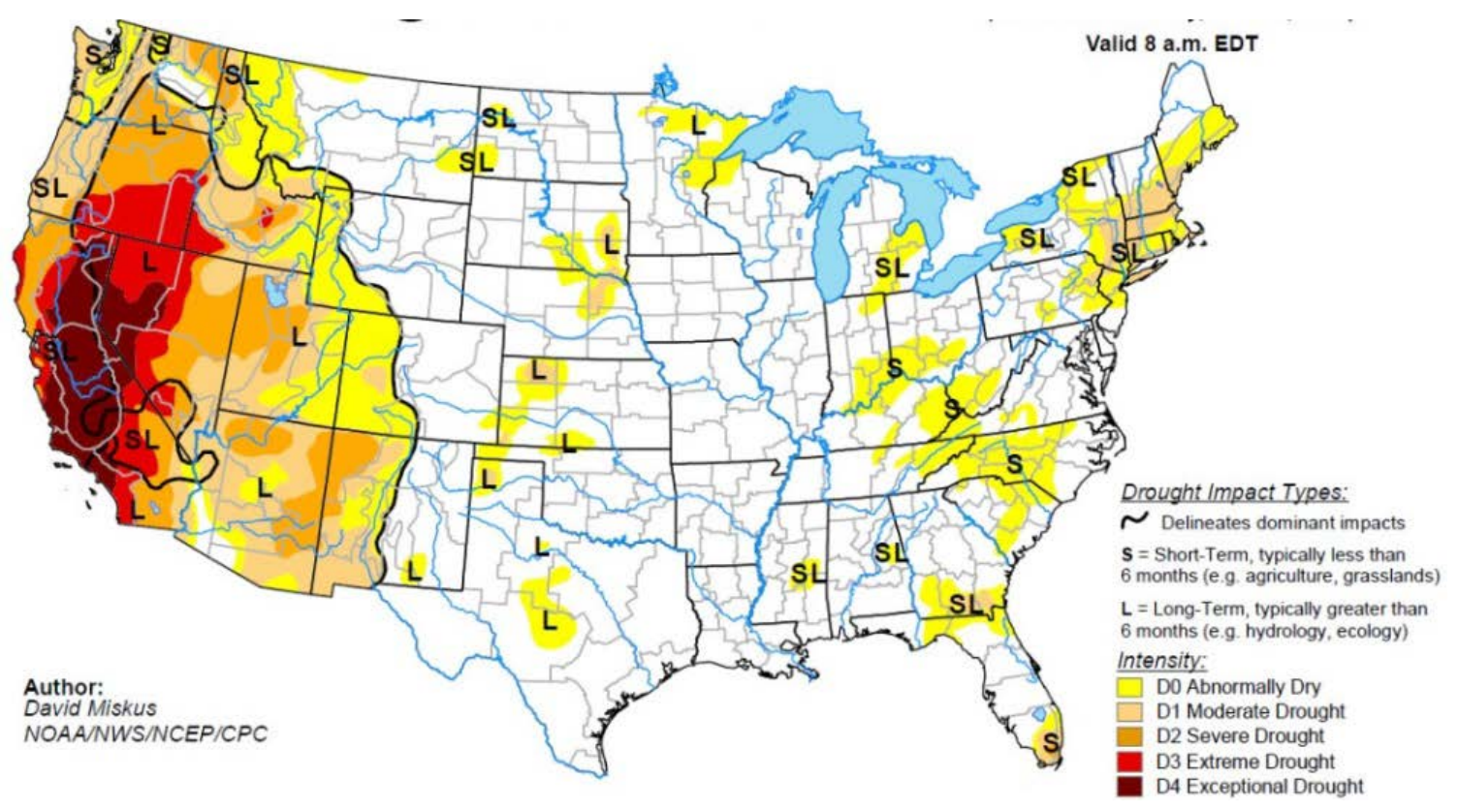

Figure 27. Drought Monitor Map of the United States as of June 9, $2015^{115}$ 

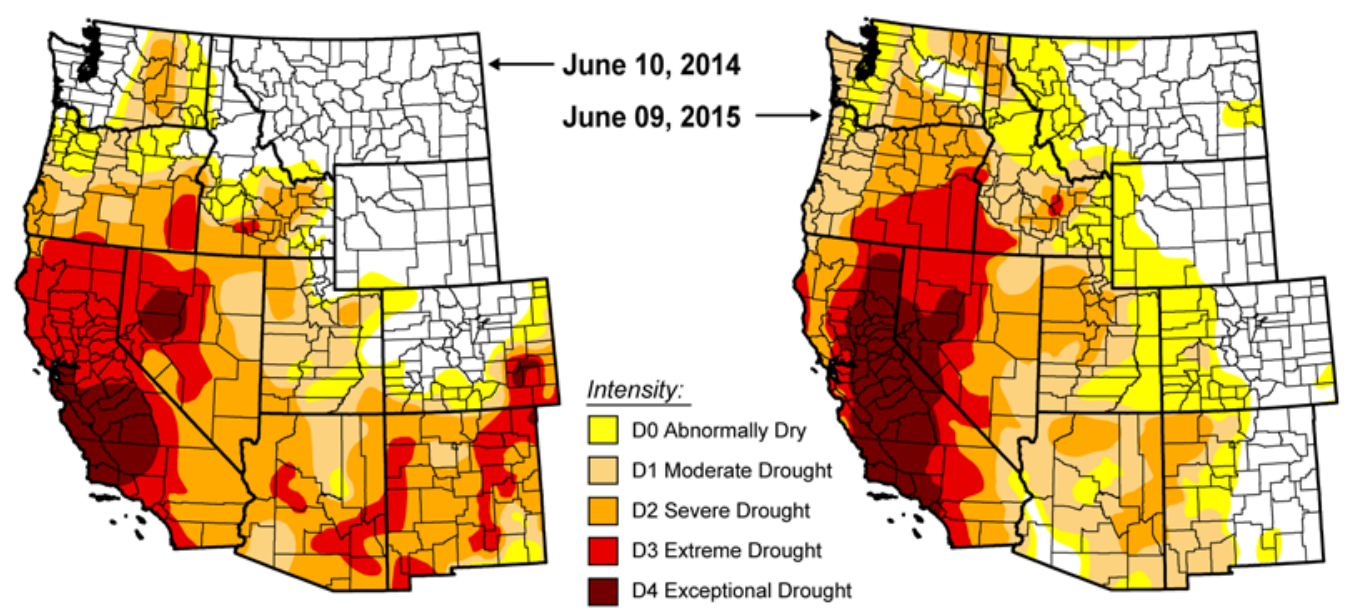

Figure 28. Western U.S. drought maps comparing June 9, 2015 and June 10, 2015 ${ }^{116}$

California, in particular, has been hard hit with persistent drought. As of June 2015, over 37 million Californians were affected by drought. ${ }^{117}$ Current drought and future water uncertainty has led California to examine alternative sources of water. One example of this is increasing interest in the desalination of seawater or impaired water sources as a source of fresh water. For example, the San Diego County Water Authority placed a 30-year water purchase agreement for fresh water from the 50 MGD Carlsbad Desalination Project on the California coast. ${ }^{118}$

In April 2015, Governor Brown passed Executive Order B-29-15 outlining a strategy to deal with the unprecedented conditions. The Governor's plan calls for more conservation as well as promotion of renewable-energy-powered desalination systems and other technological advances:

This program will achieve water and energy savings and greenhouse gas reductions by accelerating use of cutting-edge technologies such as renewable energy-powered desalination, integrated onsite reuse systems, water-use monitoring software, irrigation system timing and precision technology, and onfarm precision technology.

California is ideally suited for solar desalination with excellent solar resources and also high levels of agricultural waste and brackish water available as source water. ${ }^{119}$ Availability of brackish groundwater in states such as California, New Mexico, and Texas offers potential sources of water for desalination that could be used as an alternative fresh water supply.

\subsubsection{Desalination Technologies and the fit with Solar-Thermal}

Over the last decade there has been growing interest in the use of renewable energy for desalination processes. ${ }^{120}$ For example, wind or solar-electric (PV or CSP) systems can supply power to operate reverse osmosis (RO) plants, or heat from CSP steam systems can be used directly within thermal desalination processes.

Desalination is the removal of salt and the purification of brine or brackish water to produce potable water. Drought and scarcity of drinking water is becoming a key issue in many parts of 
the world. In the arid Middle East, counties such as Qatar and Kuwait rely entirely on desalinated water for domestic and industrial supplies. ${ }^{121}$

Several studies have reviewed the current state of desalination technologies, including solar and CSP desalination. ${ }^{122}$ Desalination technologies can be subdivided by the primary energy type required (e.g., thermal or electric), or by the nature of the system hardware (e.g., membranebased or evaporation-based systems). A breakdown of desalination technologies by the process is provided in Table 12.

Table 12. Overview of Desalination Technologies ${ }^{123}$

\begin{tabular}{|c|c|c|}
\hline $\begin{array}{c}\text { Process Driving } \\
\text { Power }\end{array}$ & Evaporation & \multirow{2}{*}{ Membrane-based } \\
\hline \multirow{4}{*}{ Thermal } & Multi-stage Flash (MSF) \\
\cline { 2 - 3 } & Multi-effect Distillation (MED) \\
\cline { 2 - 3 } & Solar Stills \\
\cline { 2 - 3 } & Multi-effect Humidification \\
\cline { 2 - 3 } & Membrane Distillation (MD) \\
\hline \multirow{2}{*}{ Electrical } & Mechanical Vapor Compression & Electrodialysis \\
\cline { 2 - 3 } & & Reverse Osmosis (RO) \\
\hline
\end{tabular}

Note: Membrane distillation straddles the usual desalination categories in that it is a membrane-based, evaporative technology.

Worldwide, desalination is dominated by RO, MSF, and MED. As of 2013, RO made up about $68 \%$ of the global market for desalinated water and the thermal processes MSF and MED made up $30 \%$. This amounted to a global production capacity of desalinated water of 81 million $\mathrm{m}^{3} /$ day. ${ }^{124}$ The lowest-cost desalination technology is RO, while thermal desalination techniques such as MSF and MED offer more robust operation and the ability to treat water with very high salinity levels. Worldwide, the wholesale cost of desalinated seawater is in the range of $\$ 0.7$ to $\$ 1.1 / \mathrm{m}^{3}$, depending on the technology and cost of energy. ${ }^{125}$ This compares with the median retail price for water in U.S. cities is about $\$ 1.5 / \mathrm{m}^{3} .{ }^{126}$ Comparing the cost for desalinated water (of any source) with the average price of potable water in U.S. cities suggests that the economic deployment of solar desalination requires first finding applications where desalinated water of any form is economically viable and then providing a case for the ability of solar energy sources to provide lowest-cost energy (thermal or electric) for the process.

Thermal desalination processes such as MED and MSF evaporate water at temperatures of 55$70^{\circ} \mathrm{C}$ and $90-120^{\circ} \mathrm{C}$ respectively. ${ }^{127} \mathrm{RO}$ processes water with membranes, using high pressure to overcome the normal osmotic pressure and drive water through the membrane while excluding ions. ${ }^{128}$ NREL published a review of renewable energy and desalination in $2013 ;{ }^{129}$ in the present report we will focus on the thermal technologies that could be integrated with solarthermal collectors.

With regards to solar-thermal desalination, there are several system possibilities that have been researched and/or pilot tested. These include CSP-RO, CSP-MED, CSP-MSF and CSP-ROMED. ${ }^{130}$ Figure 29 shows the potential configurations for CSP-desalination systems. In a "power only" CSP-RO configuration, electric power from a CSP plant drives the RO system. This design could just as easily pull electric power off the grid, so the challenge for such a design is no 
different than any electric generation CSP application, namely, the CSP plant must produce costcompetitive electricity. "Heat only" or "CHP" designs offer more opportunity for synergistic integration with solar-thermal collector technologies. A CSP-RO-MED plant where the thermal requirements of MED are met by CSP or steam-cycle waste heat and the electricity produced drives the RO process has been proposed, though none have been built. ${ }^{131}$

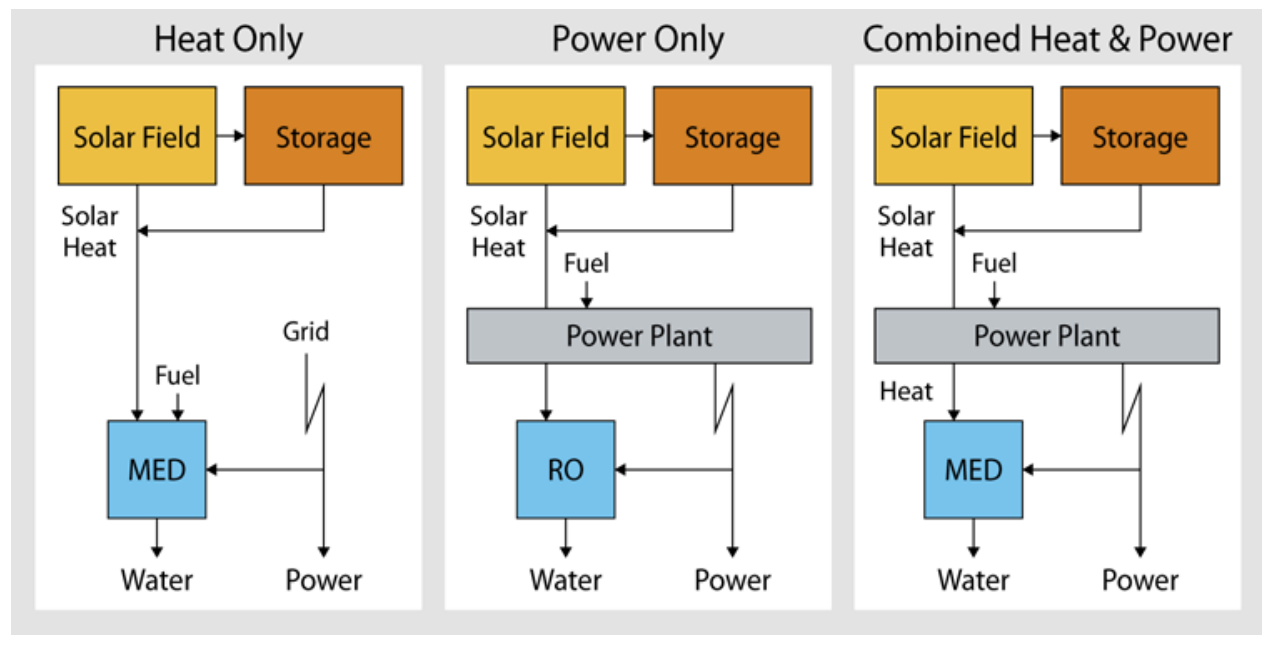

Figure 29. CSP configurations currently under interest using RO and MED ${ }^{132}$

Working in collaboration with the Advanced Water Technology Center (AQWATEC) at the Colorado School of Mines, NREL is exploring the attributes of thermal desalination technologies for integration with renewable energy sources such as geothermal and solar thermal. ${ }^{133}$ The team has identified membrane distillation (MD) as a technology of particular interest for geothermal and solar-thermal desalination. MD was originally proposed in the 1960s, but has only recently been the subject of commercial interest because the technology to produce thermally stable membranes has improved. Traditionally MD was seen as inferior to RO, however, MD offers several potential advantages including:

- Produces superior product water quality compared to RO. High-purity product water is a general characteristic of thermal-desal technologies

- Can treat higher salinity brines than RO

- Utilizes low-grade heat for its primary energy input $\left(<90^{\circ} \mathrm{C}\right)$

- Accommodates sensible (e.g., hot water) heat input

- Operates at near-ambient pressure

- Uses lower cost membranes due to pressure and temperature conditions that allow use of inexpensive plastics (e.g., polyvinylidenefluoride (PVDF), polypropylene) as construction material and a pore size orders of magnitude larger than required for RO membranes

- Can accommodate a modular design that is amenable to small-scale facilities

- Can tolerate variable operating conditions, including recurring stop/start cycles. 
The basic components of a MD system are depicted in Figure 30. There are various implementations of the basic MD technology to improve efficiency (for example, air-gap MD, vacuum-MD, and sweep-gas MD), but they share the attributes listed above.

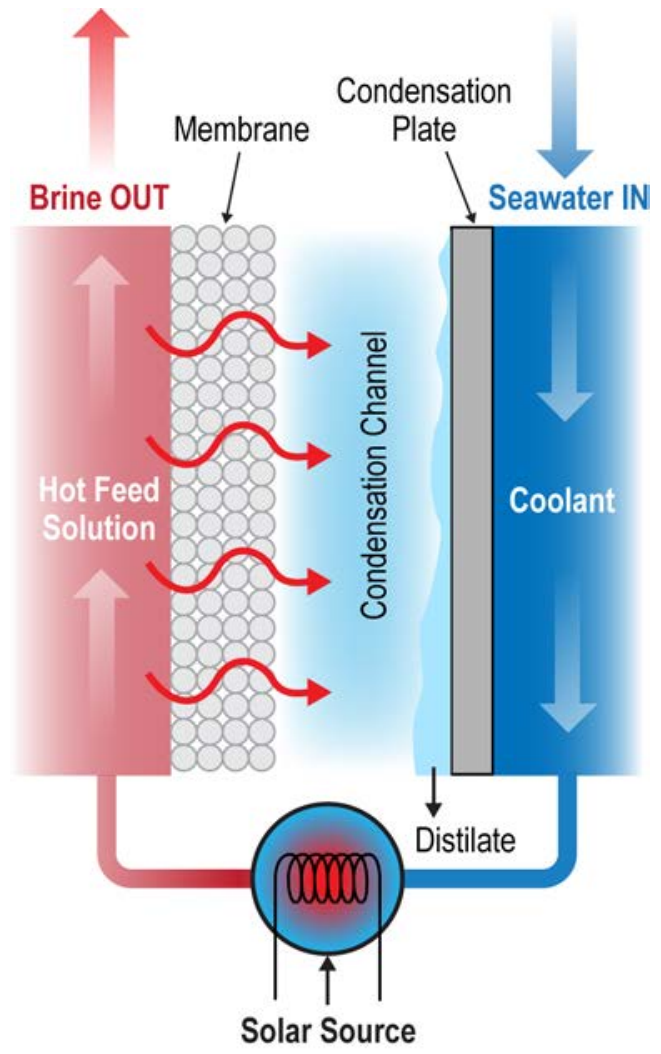

Figure 30. Basic MD system

A heat source (e.g., solar energy) warms the saline water to $50-70^{\circ} \mathrm{C}$ allowing water vapor to permeate through the membrane (left). Upon contact with the incoming cool source water, the water vapor condenses (and preheats).

The economics of MD systems depend greatly on the availability of low-cost thermal energy. ${ }^{134}$ Camacho's review of the literature indicates that MD can produce high-purity water from poorquality source water at a cost in the range of $\$ 1.2 / \mathrm{m}^{3}$, which could be lowered to less than $\$ 0.5 / \mathrm{m}^{3}$ if low-cost heat is available. For comparison, the lowest-cost desalination technology (RO) is nominally between $\$ 0.5 / \mathrm{m}^{3}$ and $\$ 1.0 / \mathrm{m}^{3}{ }^{3}{ }^{135}$ While certain researchers have proposed the use of CSP-RO, particularly for the Arabian and Mediterranean areas, ${ }^{136}$ there is a significant weakness in that approach as the thermal energy from the CSP plant is first converted from heat to electricity to drive the RO process. As such, the potential advantage for CSP or solar-thermal collectors providing heat directly is lost.

Competing with electric-RO desalination will require low-cost thermal energy from the solar field, combined with an effective thermal-desalination process. The most likely desalination technologies for integration with a solar-thermal heat source are MED or MD. While MED is a commercial technology, MD offers the potential for small, modular units and less sensitivity to varying operating conditions. The ability of these technologies to operate at modest temperatures (e.g., less than $70^{\circ} \mathrm{C}$ ) also opens the possibility of utilizing flat-plate or solar pond collectors, such as illustrated in Figure 31. 


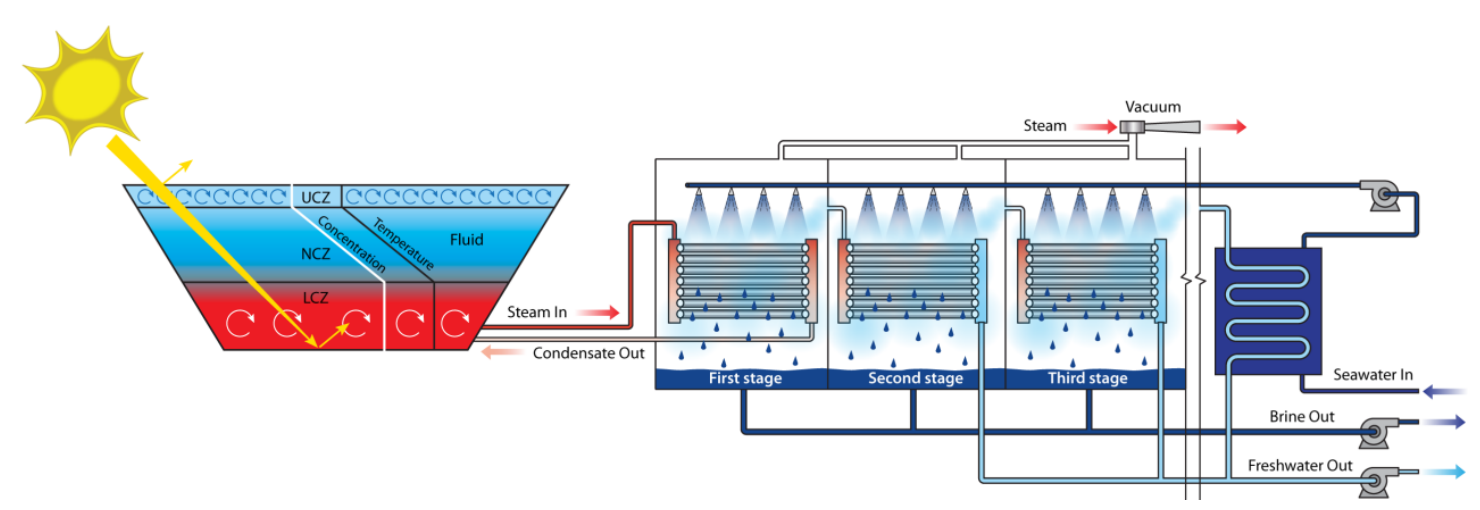

Figure 31. Solar thermal-gradient pond paired with a MED thermal desalination system ${ }^{137}$

\subsubsection{Case Study of Solar Desalination at the Panoche Desalination Plant}

The largest example of a CSP-MED desalination plant is the solar desalination demonstration in the Panoche Water \& Drainage District in California's Central Valley (Figure 32). This pilot desalination plant, built and operated by WaterFX, has been in operation since 2013 and has a net installed collector area of $656 \mathrm{~m}^{2} .{ }^{138}$ Broomfield, Colorado-based SkyFuel provided a SkyTrough solar collector assembly that provides approximately $0.4 \mathrm{MW}_{\text {th }}$ of heat from the solar field to a conventional hot-water boiler. ${ }^{139}$ While designed for CSP electricity generation, the SkyTrough's design for easy assembly in the field make them amenable to smaller applications such as this pilot unit, and more generally SIPH.

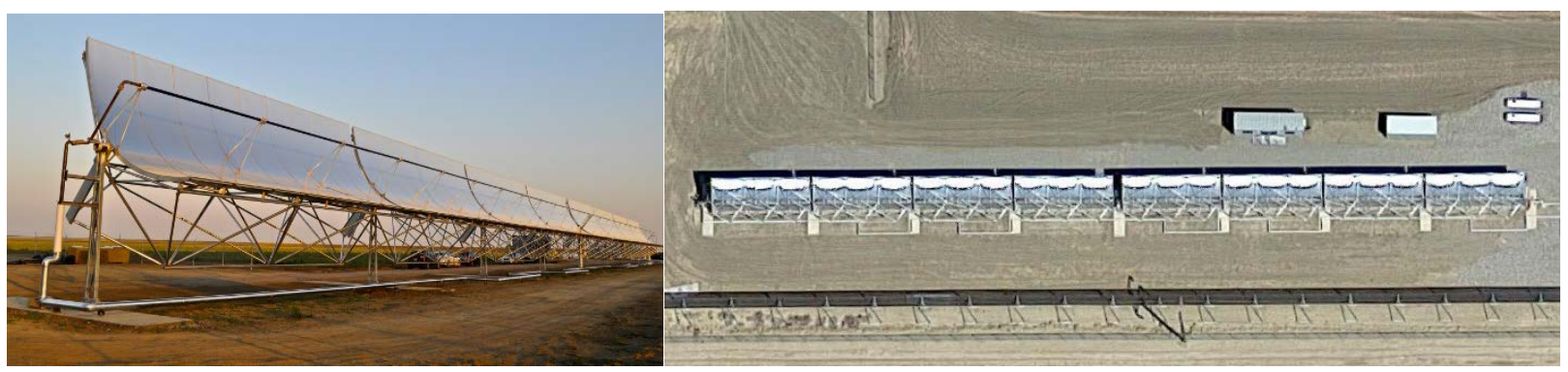

Figure 32. SkyTrough CSP collector at the Panoche desalination pilot plant ${ }^{140}$

The Panoche facility uses a 3-effect MED desalination plant. The unit was constructed to test the commercial readiness of the technology and the expected energy saving for inland desalination plants. The impaired source water for project is agricultural drainage water, which is a disposal liability for the Panoche Water \& Drainage District. Project objectives include demonstrating a high rate of recovery of desalinated water and that the technology configurations are economically feasible and reliable. Successful demonstration could help increase the sustainability of agricultural land in California by reviving arid agricultural land through the production of clean water from agricultural wastewater.

To date, two configurations have been tested at the Panoche plant-namely, with and without an absorption heat pump (AHP). Trials at the site have found that the thermal energy consumption without the AHP averaged approximately $262 \mathrm{kWh}_{\mathrm{th}} / \mathrm{m}^{3}$. With the AHP the thermal energy consumption reduced to $133 \mathrm{kWh}_{\mathrm{th}} / \mathrm{m}^{3}$ (i.e., approximately half the energy demand without the AHP). ${ }^{141}$ These values correspond to a Gained Output Ratio (GOR) of 2.4 to 4.7 for the 
distillation process. GOR is defined as the mass of water produced per mass of steam fed to the process, where the mass of steam is a surrogate for the latent heat of steam. Typical GOR for a commercial MED system is about 6 to $10 .{ }^{142}$ The HTF in the solar field was a food-grade mineral oil known as Therminol XP, which was heated by the PTCs to $180^{\circ} \mathrm{C}$. The pilot plant has successfully been operating and the thermal energy provided for the evaporation and distillation of the brackish/agricultural waste water has been shown to desalinate 14,000 gallons/day or about $53 \mathrm{~m}^{3} /$ day. ${ }^{143}$

As noted, the SkyTrough was designed for electric-power generation while the Panoche plant operates at a solar field exit temperature of $180^{\circ} \mathrm{C}$. This is a significant underutilization of the SkyTrough collector as optical and thermal validation have shown that the SkyTrough can reach $390^{\circ} \mathrm{C} .{ }^{144} \mathrm{~A}$ key issue that the demonstration revealed is that PTCs developed for electricity generation may require adaption and redesign for use in solar-thermal desalination. Discussions with WaterFX have indicated that further development of PTCs is needed, particularly because of cost implications for installing large PTCs.

Cost information related to the Panoche desalination pilot has not been released, and the cost of desalinated water, regardless of energy source, continues to be expensive compared to alternative sources. Importantly, this project benefits from two sources of value-it mitigates the problem of disposal of saline agricultural drainage water while producing fresh water as a product. It is likely that such dual-benefit designs will be necessary to make desalinated water economically viable. In July 2015, WaterFX announced a planned expansion of the project to a 35-acre site. WaterFX has highlighted that the continued success at the Panoche plant makes it viable to build a commercial scale, 10-effect CSP-MED desalination plant. The strategic focus for WaterFX will remain the agricultural wastewater market. The new plant is expected to utilize a $24-\mathrm{MW}_{\text {th }}$ solar field of CSP concentrators and potentially produce 2,000 acre-ft of water per year, or $2 \mathrm{MGD}{ }^{145}$ WaterFX highlighted that the plant is expected to utilize thermal energy storage to allow for 24hour operation. After demonstrating success at this first commercial site, WaterFX intends to construct commercial solar-thermal desalination plants at other sites in California. 


\section{Conclusions}

This study considers the use of solar-thermal energy for application to IPH in the United States, with focus on the state of California. For most industrial applications, the steam or direct-heat temperature required typically is less than $260^{\circ} \mathrm{C}$. This temperature is beyond the range that can be achieved with flat-plate collectors, but ideal for concentrating solar collectors such as parabolic troughs and linear Fresnel systems. This study examines applications for these linearfocus collectors, which can readily achieve these temperatures with hot liquid or steam heat transfer fluids.

A key part of this study has been matching known areas of high DNI to both states and industries that utilize high quantities of natural gas, specifically for direct process heating and conventional boiler use to generate steam. The investigation utilized previous research to identify the five industrial sectors that are the biggest users of steam at less than $260^{\circ} \mathrm{C}$ at both the national and California state level: food, paper, petroleum, chemicals, and primary metals.

As of 2014, California was the third-biggest user of industrial natural gas in the United States, behind only Texas and Louisiana. Due to its use of natural gas to provide steam or heat for industrial processes, coupled with excellent DNI conditions, California is well-suited to consider deploying SIPH. At the time of writing, California's CSI-T incentive program offers industrial sites up to $\$ 800,000$ to set up a SIPH plant for the displacement of natural gas. Solar technology developers estimate that under this program, even with the relatively low gas prices today, simple payback on these projects could be less than three years. This will need confirmation through further NREL analysis, but with the high DNI levels, excellent gas displacement incentives and high industrial gas use for California, this may be a feasible payback period. A complementary follow-on analysis to this study would be site-specific case studies that identify promising early adopter locations to promote deployment of SIPH within the state.

Within California the thermal energy demand of the food, paper, petroleum, chemicals, and primary metals industries derived from the use of natural gas was calculated. It was found that these five key industries in California had an estimated demand of about $48 \mathrm{TWh}_{\mathrm{th}} / \mathrm{yr}$ for direct process heating and conventional boiler use. This was shown to be two orders of magnitude less than the state's technical thermal energy potential from solar-thermal collectors. The annual 48 $\mathrm{TWh}_{\text {th }}$ demand within the state is the thermal energy equivalent of about 140 Nevada Solar Onesize solar-thermal plants. 140 such large sized plants spead across California is a reasonable amout to meet a significant amount of the state's industrial heat demand. As mentioned, SIPH plants for IPH provision would be much smaller than a Nevada Solar One solar field and so would require significantly less capital expenditure, making them more feasible for industry.

SIPH has been shown to be directly usable in many industries and processes due to the heat and steam that can be provided by concentrating solar collectors. SIPH plants have been utilized as far north as Canada and Germany, where the DNI resource is much lower than that available in California. At the time of writing, of the 155 worldwide SIPH plants in the international database, only 18 of these global SIPH sites employed parabolic trough (PTCs) or LF concentrators. To note, there were 18 SIPH sites within the U.S. where both concentrating and nonconcentrating collectors were used. Of the 18 SIPH sites in the U.S., only two utilized PTCs (both in California). 
However, several additional parabolic trough plants not listed in the database are known to operate in the United States, producing hot water at federal prison sites. The research has found that globally, PTC and LF collectors have been used by breweries, dairy and milk processing producers, pharmaceuticals, paper, food and meat processing, enhanced oil recovery, and desalination. At the time of writing, PTCs were more common in the market for SIPH compared to LFs.

Based on developer information, a realistic cost for an installed SIPH solar field is about $\$ 200 / \mathrm{m}^{2}$. At that cost, and including other costs for piping, pumps, and heat exchangers, solarthermal energy is competitive with natural gas combustion at the average California price of $\$ 7.6 /$ MMBtu (2014) for locations with solar DNI greater than about $6.0 \mathrm{kWh} / \mathrm{m}^{2} /$ day. However, the same solar field cost is not competitive with natural gas at its reported national average price of \$5.4/MMBtu, regardless of DNI level. Other reasons industrial users could opt for SIPH deployment at the industrial site could also be long-term hedging against fuel-price volatility and for industries such as Food, Dairy and Beverage, increasing the green image of their products. The data suggest that economic SIPH applications can be found in California at existing solar hardware costs and market gas prices. However, project viability will be strongly dependent on the specific solar project costs-including any incentives-and the specific gas pricing contract in place. It will be important to validate that SIPH for specific industrial sites are both feasible and provide real economic benefit. 


\section{Future Analyses Possibilities}

One result of this study has been the identification of areas where future investigation could facilitate the deployment of solar-thermal collectors for SIPH. These recommendations include:

1. Undertake a higher-resolution assessment of the technical thermal energy potential for SIPH in the Southwest.

- Key assumptions made in this investigation would be refined to account for solar collectors specifically designed for SIPH at less than $260^{\circ} \mathrm{C}$ and the smaller amount of land needed for SIPH facilities. Such revisions are likely to increase the thermal energy potential of SIPH in California and the Southwest.

- A higher-resolution understanding of the technical thermal energy potential will provide a more accurate assignment of available land adjacent to potential userindustry sites. This would highlight the best potential SIPH locations.

2. Identify case studies of potentially attractive SIPH projects to disseminate facts and data regarding the SIPH potential, which could increase deployment interest.

- Case study development would benefit from interaction with industrial partners and solar hardware developers. Accordingly, NREL and DOE could consider fostering relationships with SIPH developers and industrial partners to identify potential cost-shared case studies.

- Identifying good candidate projects for SIPH could help industry and the solar developers explore and develop early-adopter projects. NREL's expertise can be utilized to provide independent validation of the potential and the subsequent performance of SIPH projects (for example determining the solar thermal yield and the expected payback period). Dissemination of success stories could aid expansion of the SIPH market.

- Identify locations requiring IPH, but without access to natural gas. Natural gas prices in the United States are very low compared to historic values and most of the world. Locations without access to natural gas pipelines that are required to use propane, fuel oil or electricity for IPH would provide much better economics for SIPH.

3. Track SIPH applications and research worldwide.

- NREL has been instrumental in developing databases and tracking CSP project development. It would be valuable to perform similar market analysis for SIPH applications.

- This research has highlighted industries such as food, paper, and petroleum sectors that could benefit from SIPH integration due to the steam and temperature requirements. This research has looked at the overall industry level, and with future efforts; it will be worthwhile investigating specific subsectors in a specific industry (e.g. the Dairy Producers in the Food Industry, MECS 3115).

○ Market tracking of SIPH applications and research around the world will allow technology developments to be identified for potential use in the United States. This engagement would be enhanced by NREL reconnecting with the 
international research community for SIPH via collaborative projects e.g IEA Task 49.

4. Understand industrial natural gas consumption and burner tip pricing in each state within the Southwest for the food, paper, petroleum, chemical and primary metals industries.

- Estimate the thermal energy demand for natural gas in each state and industry and compile the data into a public database.

- Understanding the thermal energy demand by industry and state where natural gas is utilized for steam production will highlight the potential to significantly decrease natural gas use using solar-thermal and SIPH. 


\section{Appendix A. Industry Sectors with Potential for SIPH Application}

Table 13. Studies globally regarding industries that could be suitable for SIPH applications ${ }^{146}$

\begin{tabular}{|l|c|c|c|c|c|c|c|}
\hline Industry Sector & Austria & $\begin{array}{c}\text { Spain and } \\
\text { Portugal }\end{array}$ & Italy & Netherlands & Greece & Germany & Australia \\
\hline Food Products & $\checkmark$ & $\checkmark$ & $\checkmark$ & $\checkmark$ & $\checkmark$ & & $\checkmark$ \\
\hline $\begin{array}{l}\text { Wines and } \\
\text { Beverage }\end{array}$ & $\checkmark$ & $\checkmark$ & $\checkmark$ & $\checkmark$ & & & \\
\hline Beer and Malt & & $\checkmark$ & $\checkmark$ & $\checkmark$ & & $\checkmark$ & $\checkmark$ \\
\hline Tobacco & & $\checkmark$ & $\checkmark$ & & $\checkmark$ & & \\
\hline Textiles & $\checkmark$ & $\checkmark$ & $\checkmark$ & $\checkmark$ & $\checkmark$ & & $\checkmark$ \\
\hline $\begin{array}{l}\text { Leather and } \\
\text { Products }\end{array}$ & & $\checkmark$ & $\checkmark$ & & & & \\
\hline $\begin{array}{l}\text { Pulp and Paper } \\
\text { products }\end{array}$ & & $\checkmark$ & $\checkmark$ & & & & \\
\hline Chemical & & $\checkmark$ & $\checkmark$ & & $\checkmark$ & & $\checkmark$ \\
\hline
\end{tabular}




\section{Appendix B. Fuel Use by Type and End Use}

Table B-1. End use fuel consumption for all MECS 2010 industries in the United States

\begin{tabular}{|l|c|c|c|}
\hline End Use Category & $\begin{array}{c}\text { Net } \\
\text { Electricity }\end{array}$ & Natural Gas & Coal \\
\hline Indirect End Use (Boiler Fuel) & Trillion Btu & Trillion Btu & Trillion Btu \\
\hline Conventional Boiler Use & 44 & 2,134 & 572 \\
\hline CHP and Cogeneration Process & 44 & 733 & 72 \\
\hline Direct End Use & 0 & 1,401 & 500 \\
\hline All Process Uses & 2,304 & 2,623 & 289 \\
\hline Process Heating & & & \\
\hline Process Cooling and Refrigeration & 318 & 2,362 & 280 \\
\hline Machine drive & 208 & 25 & 0 \\
\hline Electrochemical Processes & 1,454 & 120 & 1 \\
\hline Other Process Uses & 263 & 0 & 0 \\
\hline All Non-Process Uses & 60 & 117 & 8 \\
\hline Facility Heating, Ventilation and Air & & & 3 \\
\hline Conditioning & 236 & 306 & \\
\hline Facility Lighting & 177 & 0 & 0 \\
\hline Other Facility Support & 51 & 36 & * \\
\hline Onsite Transportation & 5 & 1 & 0 \\
\hline Conventional Electricity Generation & 0 & 19 & 1 \\
\hline Other Non-Process Use & 10 & 7 & 1 \\
\hline End use Not Reported & 59 & 86 & 1 \\
\hline Total & & $\mathbf{5 , 2 1 1}$ & $\mathbf{5 7 2}$ \\
\hline
\end{tabular}

Figure 33 and Figure 34 show the MECS 2010 end-use subcategories for natural gas and electricity, respectively. Natural gas is most often used for process heating, conventional boiler use, and CHP or cogeneration. In contrast, electricity is most commonly used for direct machine drive with some use in process heating. Steam generation with electricity is rare. 


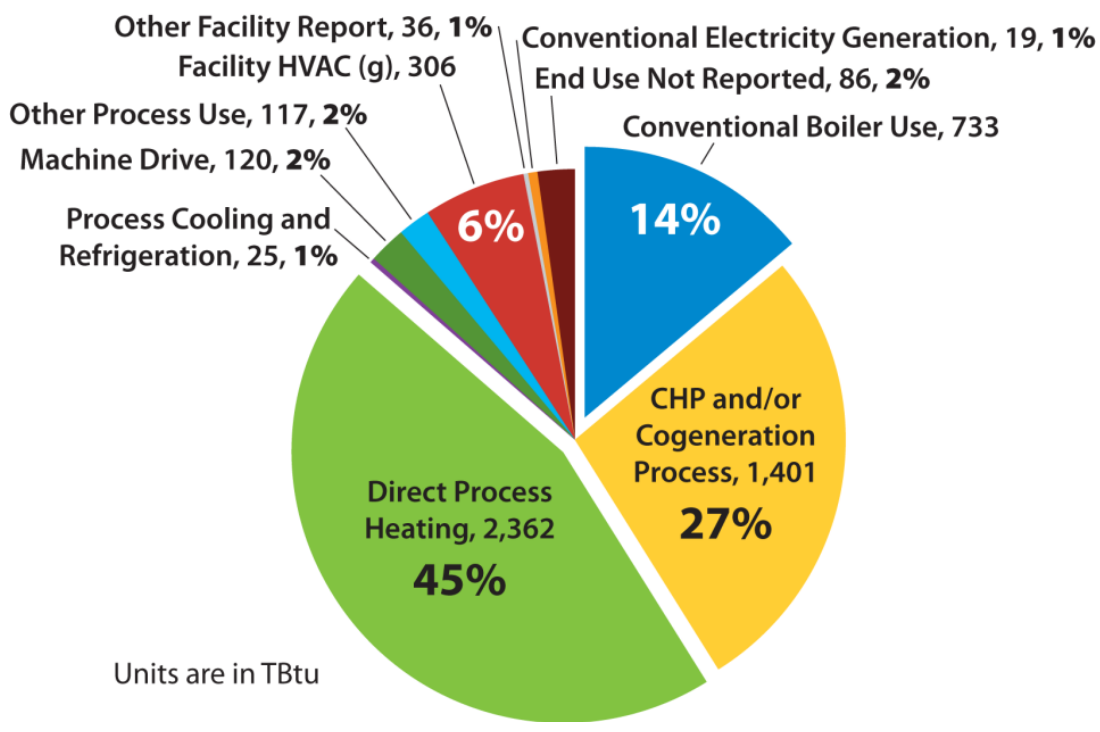

Figure 33. 2010 MECS overall natural gas breakdown by end use $e^{147}$

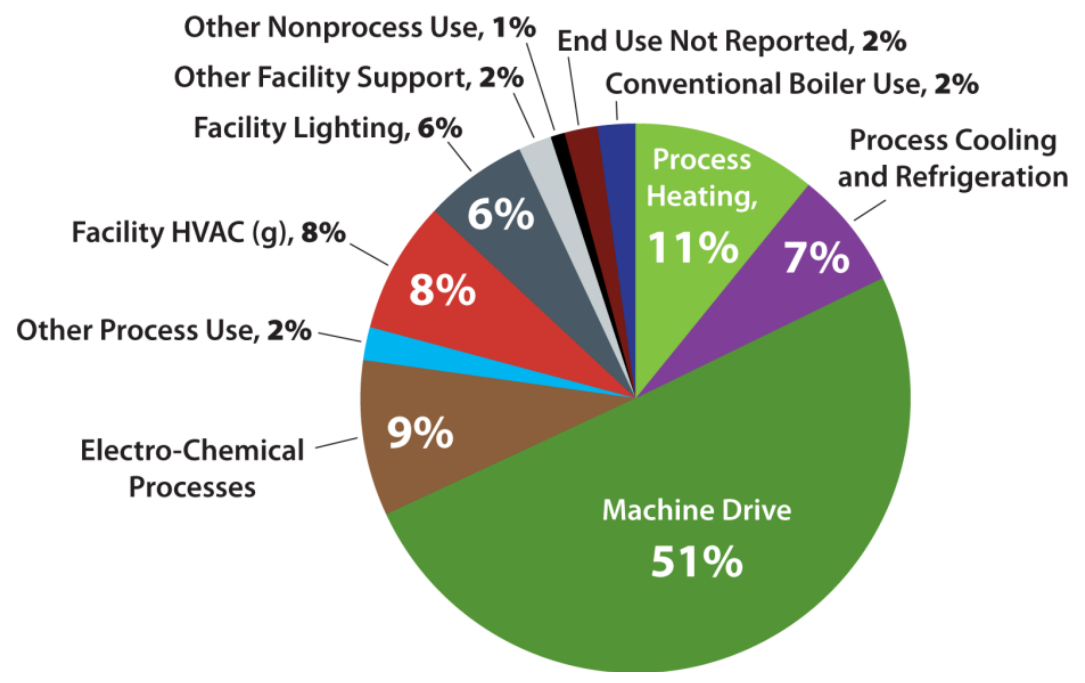

Figure 34. 2010 MECS overall electricity end use breakdown ${ }^{148}$ 


\section{Appendix C. Thermal Energy Potential of California}

Table C-1. Annual technical thermal energy potential by county in California

\begin{tabular}{|l|l|l|l|}
\hline County Name & Total $\mathbf{G W h}_{\text {th }}$ & County Name & Total $\mathbf{G W h}_{\text {th }}$ \\
\hline Alameda & 9,699 & Riverside & $1,240,830$ \\
\hline Alpine & 1,365 & Sacramento & 323,108 \\
\hline Amador & 30,814 & San Benito & 58,989 \\
\hline Butte & 311,319 & San Bernardino & $4,353,578$ \\
\hline Calaveras & 22,724 & San Diego & 178,912 \\
\hline Colusa & 323,691 & San Joaquin & 637,502 \\
\hline Contra Costa & 53,609 & San Luis Obispo & 172,113 \\
\hline El Dorado & 6,273 & Santa Barbara & 81,642 \\
\hline Fresno & $1,358,464$ & Santa Clara & 17,896 \\
\hline Glenn & 288,736 & Santa Cruz & 1,117 \\
\hline Imperial & $2,055,429$ & Shasta & 246,310 \\
\hline Inyo & 757,030 & Sierra & 44,215 \\
\hline Kern & $2,245,593$ & Siskiyou & 480,529 \\
\hline Kings & 673,973 & Solano & 248,577 \\
\hline Lake & 29,051 & Sonoma & 14,692 \\
\hline Lassen & 738,986 & Stanislaus & 447,001 \\
\hline Los Angeles & 515,857 & Sutter & 279,979 \\
\hline Madera & 473,668 & Tehama & 312,606 \\
\hline Mariposa & 11,408 & Trinity & 2,211 \\
\hline Mendocino & 34,442 & Tulare & 797,613 \\
\hline Merced & 656,964 & Tuolumne & 7,995 \\
\hline Modoc & $1,142,840$ & Ventura & 46,707 \\
\hline Mono & 196,907 & Yolo & 374,672 \\
\hline Monterey & 174,323 & Yuba & 142,275 \\
\hline Napa & 25,318 & & \\
\hline Nevada & 6,487 & California Total & $\mathbf{2 2 , 8 9 7 , 3 3 7}$ \\
\hline Orange & 393 & & \\
\hline Placer & 109,635 & & \\
\hline Plumas & 131,270 & & \\
\hline & & & \\
\hline
\end{tabular}




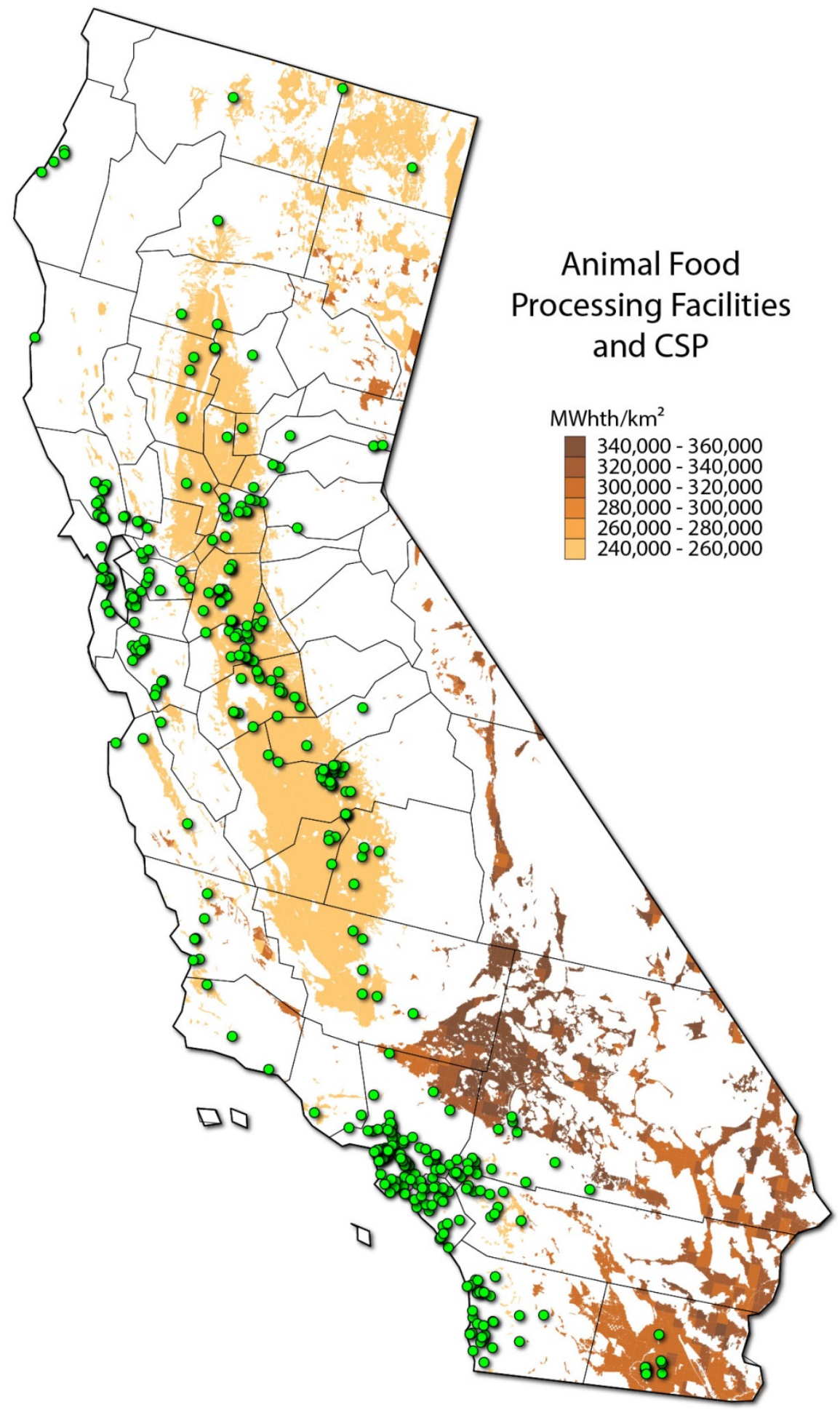

Figure 35. Solar technical thermal energy potential of CA overlaid on animal-food processing sites 


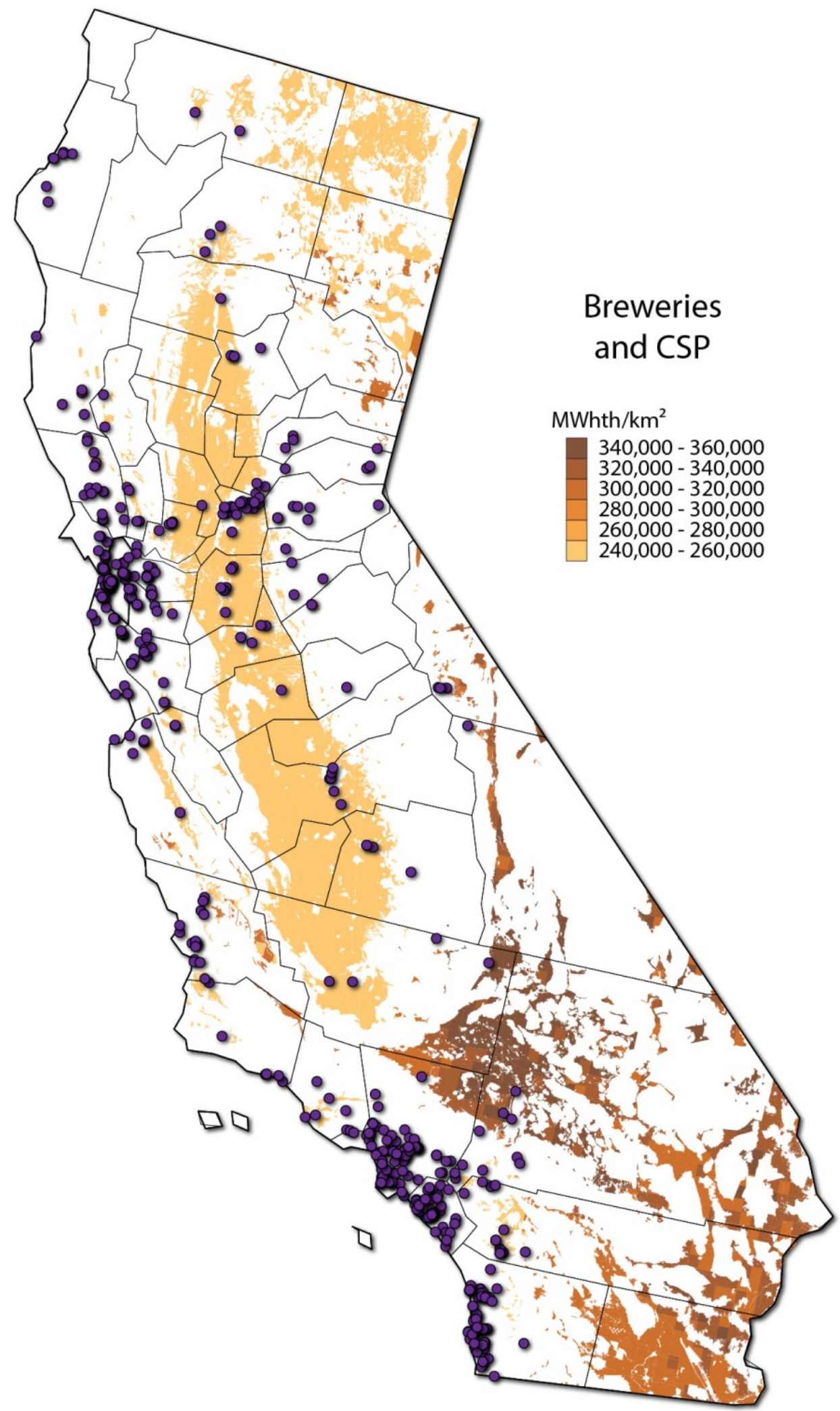

Figure 36. Solar technical thermal energy potential of CA overlaid on the breweries 


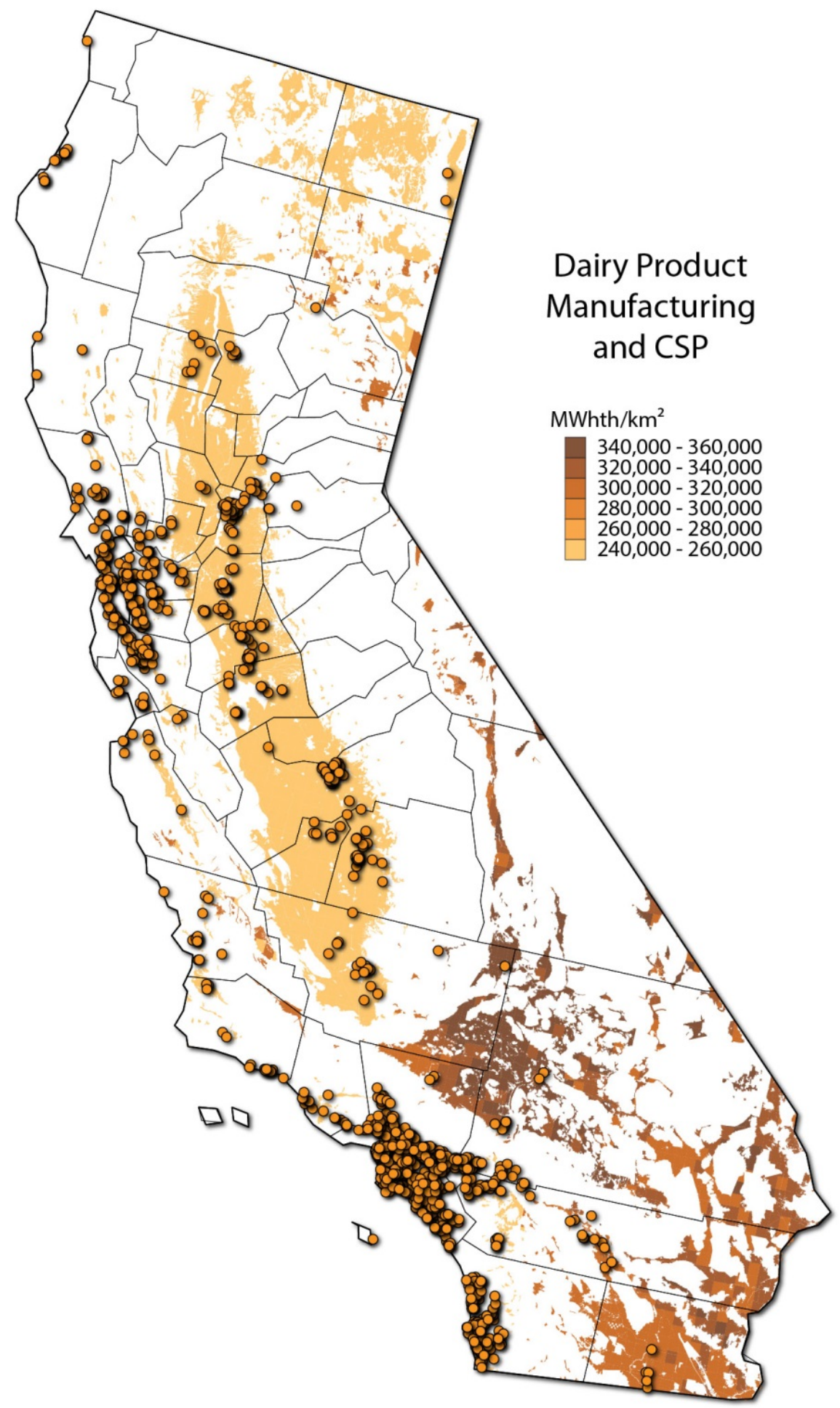

Figure 37. Solar technical thermal energy potential of CA overlaid on locations of dairy product manufacturers 


\section{Appendix D. LCOH Calculation and Assumptions}

The $\mathrm{LCOH}$ is calculated in a spreadsheet using the formula for fixed charge rate (FCR) as described in SAM version 2015-06-30. The explanation below is excerpted from SAM's help menu. An example calculation is shown using the default values for the CSP parabolic trough model in SAM 2015-06-30, with the exception of the construction period being set to one year rather than SAM's default value of three years. This change is realistic because SIPH plants are much smaller than CSP electric-generation facilities.

Table D-1. LCOH calculation method patterned after the fixed charge rate LCOE calculation in SAM 2015-06-30. Calculated values are defined in the text below.

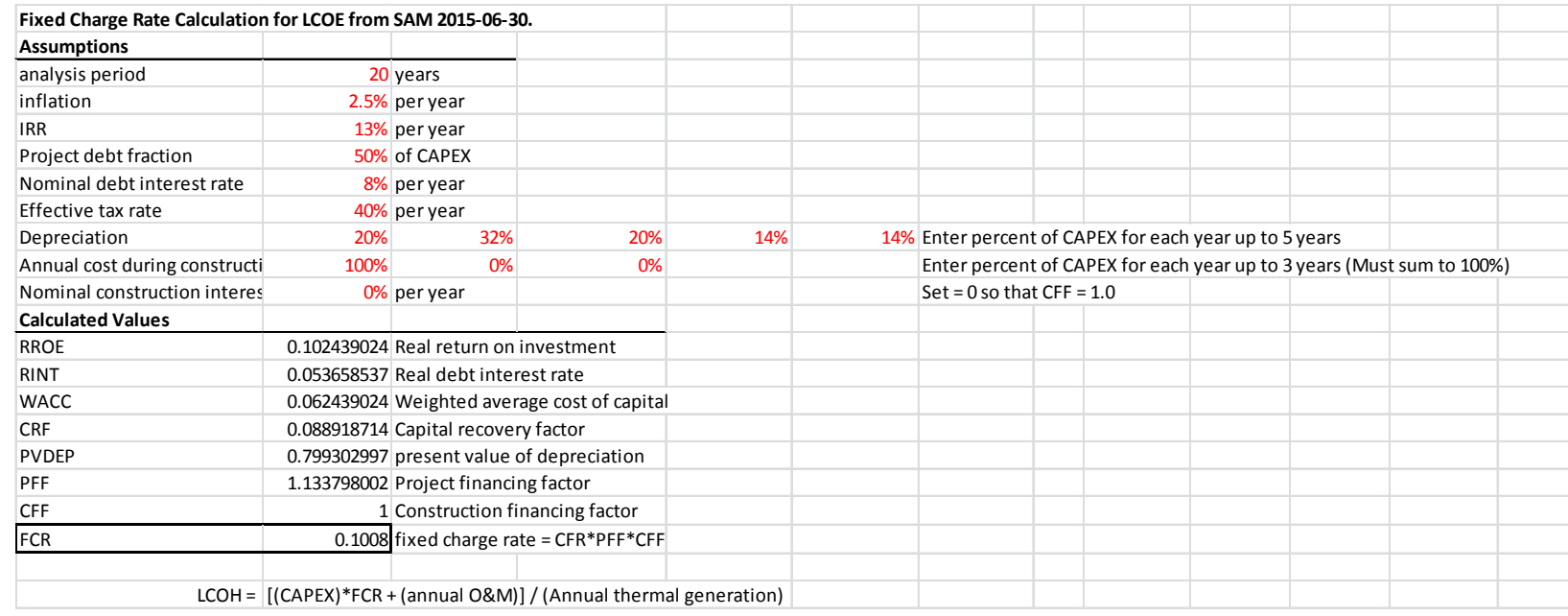

SAM's LCOE Calculator uses a simple method to calculate a project's LCOE using only the following inputs:

- $\quad$ Total Capital Cost, \$ (TCC)

- $\quad$ Fixed Annual Operating Cost, \$ (FOC)

- Variable Operating Cost, $\$ / \mathrm{kWh}(\mathrm{VOC})$

- $\quad$ Fixed Charge Rate (FCR)

- Annual Electricity Production, kWh (AEP).

The LCOE Calculator uses the following equation to calculate the LCOE:

$$
\mathrm{LCOE}=\frac{\mathrm{FCR} \times \mathrm{TCC}+\mathrm{FOC}}{\mathrm{AEP}}+\mathrm{VOC}
$$

The fixed charge rate is the revenue per amount of investment required to cover the investment cost. For details, see pages 22-24 of reference (Short, Packey and Holt 1995). This method is an alternative to the cash flow method used by SAM's other financial models. It is appropriate for very preliminary stages of project feasibility analysis before many details about the project's costs and financial structure surface. SAM does not contain a geothermal hybrid model, so direct use of SAM's other financial models is not possible. 


\section{Capital and Operating Costs}

\section{Capital cost}

The project's total investment cost.

\section{Fixed operating cost}

Annual operating costs that do not vary with the amount of electricity the system generates.

\section{Variable operating cost}

Annual operating costs in dollars per kilowatt-hour that vary with the amount of electricity the system generates.

\section{Summary}

The Summary values are the inputs to the LCOE equation. These values are calculated from the inputs you specify.

\section{Fixed charge rate}

The project fixed charge rate, or revenue per amount of investment required to cover the investment cost. Calculated from the financial details you enter.

\section{Capital cost}

The total overnight investment cost in dollars.

\section{Fixed operating cost}

The fixed annual operating cost in dollars. It is either the value you enter or a value that SAM calculates based on the value you enter in dollars per kilowatt.

\section{Variable operating cost}

The variable annual operating cost in dollars per kilowatt-hour that you enter.

\section{Financial Assumptions}

The fixed charge rate represents details of the project's financial structure.

\section{Calculate fixed charge rate}

SAM calculates the fixed charge rate from a set of financial assumptions. SAM uses the following equation to calculate the value from the capital recovery factor, project financing factor, and construction financing factor (see below for all equations):

$$
\mathrm{FCR}=\mathrm{CRF} \times \mathrm{PFF} \times \mathrm{CFF}
$$

\section{Fixed charge rate}

The project's fixed charge rate. Note that the value is a factor (between 0 and 1) rather than a percentage.

\section{Analysis period}

The number of years that the project will generate electricity and earn revenue. 


\section{Inflation rate}

The annual inflation rate over the analysis period.

\section{Internal rate of return}

The project's annual rate of return requirement.

\section{Project term debt}

The size of debt as a percentage of the capital cost.

\section{Nominal debt interest rate}

The annual nominal debt interest rate. SAM assumes that the debt period is the same as the analysis period.

\section{Effective tax rate}

The total income tax rate. For a project that pays both federal and state income taxes, where the state income tax is deducted from the federal tax, you can calculate the effective tax rate as:

$$
\mathrm{TAX}=\mathrm{STATE}+\mathrm{FED} \times(1-\mathrm{STATE})
$$

\section{Depreciation schedule}

The annual depreciation schedule. The depreciation basis equals the project's capital cost.

\section{Annual cost during construction}

The annual construction cost as a percentage of the project's capital cost. If the construction period is one year or less, enter a single value. If it is more than one year, enter a schedule of annual percentages.

\section{Nominal construction interest rate}

The annual interest rate on construction financing.

\section{Capital recovery factor (CRF)}

SAM calculates this value from the inputs you specify as described below.

\section{Project financing factor (PFF)}

Factor to account for project financing costs. SAM calculates this value from the effective tax rate and depreciation schedule, as described below.

\section{Construction financing factor (CFF)}

Factor to account for construction financing costs. SAM calculates the value from the construction cost schedule, effective tax rate, and construction interest rate, as described below. 


\section{Equations for FCR Calculation}

When you use the Calculate fixed charge rate option, SAM uses the following equations to calculate the financing factors.

\section{Nomenclature}

- $\mathrm{c}=$ Construction year

- $\mathrm{C}=$ Construction period in years

- $\mathrm{CON}=$ Construction schedule

- $\mathrm{DF}=$ Project term debt fraction

- $\mathrm{i}=$ Inflation rate

- $\mathrm{n}=$ Analysis year

- $\mathrm{N}=$ Analysis period

- $\quad \mathrm{IRR}=$ Nominal return on investment

- $\quad$ NINT $=$ Nominal debt interest rate

- $\quad \mathrm{PVDEP}=$ Present value of depreciation

- $\quad$ RINT $=$ Real debt interest rate

- $\quad \mathrm{RROE}=$ Real return on investment

- $\mathrm{TAX}=$ Effective tax rate

- $\mathrm{WACC}=$ Weighted average cost of capital (real).

The capital recovery factor (CRF) is a function of the weighted average cost of capital (WACC) and analysis period $(\mathrm{N})$ :

$$
\mathrm{CRF}=\frac{\text { WACC }}{1-\frac{1}{(1+\text { WACC })^{N}}}
$$

Where:

$$
\begin{gathered}
\text { WACC }=\frac{1+((1-\mathrm{DF}) \times((1+\mathrm{RROE}) \times(1+\mathrm{i})-1))+\mathrm{DF} \times((1+\mathrm{RINT}) \times(1+\mathrm{i})-1) \times(1-\mathrm{TAX})}{1+\mathrm{i}}-1 \\
\text { RROE }=\frac{1+\mathrm{IRR}}{1+\mathrm{i}}-1 \\
\text { RINT }=\frac{1+\mathrm{NINT}}{1+\mathrm{i}}-1
\end{gathered}
$$


The project financing factor $(\mathrm{PFF})$ is a function of the effective tax rate and depreciation schedule:

$$
\mathrm{PFF}=\frac{1-\mathrm{TAX} \times \mathrm{PVDEP}}{1-\mathrm{TAX}}
$$

Where:

$$
\text { PVDEP }=\sum_{n=0}^{N} \frac{\text { DEP }_{n}}{((1+\text { WACC }) \times(1+i))^{(n+1)}}
$$

The construction financing factor (CFF) is a function of the construction cost schedule, effective tax rate, and nominal construction financing interest rate:

$$
\mathrm{CFF}=\sum_{\mathrm{c}=0}^{\mathrm{c}} \mathrm{CON}_{\mathrm{c}} \times\left(1+(1-\mathrm{TAX}) \times\left((1+\mathrm{CINT})^{(\mathrm{c}+0.5)}-1\right)\right)
$$




\section{Notes}

${ }^{2}$ Charles F. Kutscher et al., "Design Approaches for Solar Industrial Process Heat Systems."

${ }^{3}$ Stephen L. Sargent et al., "Solar industrial process heat."

${ }^{4}$ Clifton Carwile and Russell Hewitt, "Barriers to Solar Process Heat Projects: Fifteen Highly Promising (But Cancelled) Projects."

${ }^{5}$ International Energy Agency Solar Heating and Cooling Programme, "Programme Description."

${ }^{6}$ SolarPACES, "TASK IV: Solar Heat Integration in Industrial Processes."

${ }^{7}$ SHIP Plants, AEE Intec, "Solar Thermal Plants Database."

${ }^{8}$ EPA (Environmental Protection Agency), "Renewable Industrial Process Heat."

${ }^{9}$ Ibid.; Fox, Sutter, and Tester, "The Thermal Spectrum of Low-Temperature Energy Use in the United States."

${ }^{10}$ Lauterbach et al., "The Potential of Solar Heat for Industrial Processes in Germany."

${ }^{11}$ Capital Surini Group International, Inc. and Energetics, Incorporated, "Roadmap for Process Heating Technology: Priority Research \& Development Goals and Near-Term Non-Research Goals To Improve Industrial Process Heating."

${ }^{12}$ EPA (Environmental Protection Agency), "Renewable Heating and Cooling - RHC Technologies and Applications."

${ }^{13}$ Ibid.

${ }^{14}$ Christoph Brunner, "Solar Heat for Industrial Production Processes: Latest Research and Large Scale Installations."

${ }^{15}$ Ibid.; IEA (International Energy Agency), "Technology Roadmap: Solar Heating and Cooling - Foldout.”

${ }^{16}$ Christoph Brunner, "Solar Heat for Industrial Production Processes: Latest Research and Large Scale Installations."

${ }^{17}$ SHIP Plants, AEE Intec, "Solar Thermal Plants Database."

${ }^{18}$ SHIP Plants, AEE Intec, "Solar Thermal Plants Database."

${ }^{19}$ Hans Schweiger et al., "The Potential of Solar Heat in Industrial Processes: A State of the Art Review for Spain and Portugal."

${ }^{20}$ Ibid.; IEA-ETSAP and IRENA, "Solar Heat for Industrial Processes: Technology Brief”; Beath, "Industrial

Energy Usage in Australia and the Potential for Implementation of Solar Thermal Heat and Power"; Calderoni et al., "Solar Thermal Plants for Industrial Process Heat in Tunisia."

${ }^{21}$ Lauterbach et al., "The Potential of Solar Heat for Industrial Processes in Germany."

${ }^{22}$ Hans Schweiger et al., "The Potential of Solar Heat in Industrial Processes: A State of the Art Review for Spain and Portugal"; IEA-ETSAP and IRENA, "Solar Heat for Industrial Processes: Technology Brief"; Beath, "Industrial Energy Usage in Australia and the Potential for Implementation of Solar Thermal Heat and Power"; Calderoni et al., "Solar Thermal Plants for Industrial Process Heat in Tunisia."

${ }^{23}$ Calderoni et al., "Solar Thermal Plants for Industrial Process Heat in Tunisia"; Ramos, Ramirez, and Beltran, "Potential Assessment in Mexico for Solar Process Heat Applications in Food and Textile Industries."

${ }_{25}^{24}$ Lauterbach et al., "The Potential of Solar Heat for Industrial Processes in Germany."

${ }^{25}$ Ibid.

${ }^{26}$ Beath, "Industrial Energy Usage in Australia and the Potential for Implementation of Solar Thermal Heat and Power."

${ }^{27}$ Lauterbach et al., "The Potential of Solar Heat for Industrial Processes in Germany"; Hans Schweiger et al., "The Potential of Solar Heat in Industrial Processes: A State of the Art Review for Spain and Portugal"; Calderoni et al., "Solar Thermal Plants for Industrial Process Heat in Tunisia"; Ramos, Ramirez, and Beltran, "Potential Assessment in Mexico for Solar Process Heat Applications in Food and Textile Industries."

${ }^{28}$ Julia Chan, "South America's first solar thermal plant comes online."

${ }^{29}$ SHIP Plants, AEE Intec, "Solar Thermal Plants Database."

${ }^{30}$ Ibid.

${ }^{31}$ Hennecke, "Solar Process Heat and Co-Generation - A Review of Recent Developments."

${ }^{32}$ SHIP Plants, AEE Intec, "Cremo SA."

${ }^{33}$ Solarlite CSP Technology GmbH, "CSP Technologies in Practice."

${ }^{34}$ Solarlite CSP Technology GmbH, "The Sun Is Shining for You as Well."

${ }^{35}$ Solarlite CSP Technology GmbH, "CSP Technologies in Practice." 
${ }^{36}$ Solarlite CSP Technology GmbH, "’TSE 1“ Kanchanaburi, Thailand.”

${ }^{37}$ Utilities ME Staff, "German Firm Installs CSP System at Jordan Factory."

${ }^{38}$ CSP-F, "Ribbon-Cutting for the First Italian CSP Fresnel Plant in the Agrobusiness."

${ }^{39}$ Ibid.

${ }^{40}$ CSP-F, "Solar Cooling Gorla Maggiore with Fresnel Mirrors."

${ }^{41}$ Saleem Qadir Tunio et al., "Comparison of Different Enhanced Oil Recovery Techniques for Better Oil

Productivity."

${ }^{42}$ Petros Group, "EOR Classification."

${ }^{43}$ Alvarez and Han, "Current Overview of Cyclic Steam Injection Process."

${ }^{44}$ Gregory and Omom, "Solar Enhanced Oil Recovery: An in-Country Value Assessment for Oman"; Brightsource Energy, "Coalinga: Project Facts."

${ }^{45}$ Gregory and Omom, "Solar Enhanced Oil Recovery: An in-Country Value Assessment for Oman"; GlassPoint Solar Inc., "Sealed From Dust."

${ }^{46}$ Glasspoint Solar Inc., "Use Less Gas For EOR."

${ }^{47}$ Ibid.

${ }^{48}$ GlassPoint Solar Inc., "GlassPoint PDO Fact Sheet."

${ }^{49}$ Christopher Helman, "Ironic Or Economic? Oil Giant To Build World's Largest Solar Project."

${ }^{50}$ Brightsource Energy, "Coalinga: Project Facts"; eSolar Inc., "EOR - Enhanced Oil Recovery."

${ }^{51}$ Brightsource Energy, "Coalinga: Project Facts."

${ }^{52}$ Lopez et al., "U.S. Renewable Energy Technical Potentials: A GIS-Based Analysis."

${ }^{53}$ Lauterbach et al., "The Potential of Solar Heat for Industrial Processes in Germany."

${ }^{54}$ Lopez et al., "U.S. Renewable Energy Technical Potentials: A GIS-Based Analysis."

${ }^{55}$ Ibid.

${ }^{56}$ Hans Schweiger et al., "The Potential of Solar Heat in Industrial Processes: A State of the Art Review for Spain and Portugal"; Beath, "Industrial Energy Usage in Australia and the Potential for Implementation of Solar Thermal Heat and Power."

${ }^{57}$ Beath, "Industrial Energy Usage in Australia and the Potential for Implementation of Solar Thermal Heat and Power."

${ }^{58}$ Lopez et al., "U.S. Renewable Energy Technical Potentials: A GIS-Based Analysis."

${ }^{59}$ Fox, Sutter, and Tester, "The Thermal Spectrum of Low-Temperature Energy Use in the United States."

${ }^{60}$ Lopez et al., "U.S. Renewable Energy Technical Potentials: A GIS-Based Analysis."

${ }^{61}$ EERE (U.S. Department of Energy Office of Energy Efficiency and Renewable Energy), "Sankey Diagram of Process Energy Flow in U.S. Manufacturing Sector.”

${ }^{62}$ Ibid.

${ }^{63}$ EIA (U.S. Energy Information Administration), "2010 MECS Survey Data - Table 5.3, End Use of Fuel Consumption."

${ }^{64}$ EIA (U.S. Energy Information Administration), "2010 MECS Survey Data - Table 5.4, End Use of Fuel Consumption."

${ }^{65}$ Ibid.

${ }^{66}$ Fox, Sutter, and Tester, "The Thermal Spectrum of Low-Temperature Energy Use in the United States"; XENERGY Inc., "California Industrial Energy Efficiency Market Characterization Study."

${ }^{67}$ EIA (U.S. Energy Information Administration), "Annual Energy Review 2011, Table 2.3."

${ }^{68}$ Fox, Sutter, and Tester, "The Thermal Spectrum of Low-Temperature Energy Use in the United States." ${ }^{69}$ Ibid.

${ }^{70}$ Fox, Sutter, and Tester, "The Thermal Spectrum of Low-Temperature Energy Use in the United States."

${ }^{71}$ EIA (U.S. Energy Information Administration), "2010 MECS Survey Data - Table 5.3, End Use of Fuel Consumption."

${ }^{72}$ Shehabi, Morrow, and Masanet, "United States Industrial Sector Energy End Use Analysis."

${ }^{73}$ EIA (U.S. Energy Information Administration), "State Energy Data 2013: Updates by Energy Source, Table F19: Natural Gas Consumption Estimates, 2013.”

${ }^{74}$ Ibid.

${ }^{75}$ Ibid. 
${ }^{76}$ XENERGY Inc., "California Industrial Energy Efficiency Market Characterization Study”; Friedmann et al., "California Industrial Energy Efficiency Potential."

${ }^{77}$ Friedmann et al., "California Industrial Energy Efficiency Potential."

${ }^{78}$ Ibid.

${ }^{79}$ Schrupp, “The Natural Gas Research, Development, and Demonstration Program: Proposed Program Plan and Funding Request for Fiscal Year 2013-14."

${ }^{80}$ Ibid.

${ }^{81}$ Lauterbach et al., "The Potential of Solar Heat for Industrial Processes in Germany."

82 Ibid.

${ }^{83}$ Schrupp, "The Natural Gas Research, Development, and Demonstration Program: Proposed Program Plan and Funding Request for Fiscal Year 2013-14."

${ }^{84}$ Ibid.

${ }^{85}$ EIA (U.S. Energy Information Administration), "Natural Gas Prices."

${ }^{86}$ Schrupp, "The Natural Gas Research, Development, and Demonstration Program: Proposed Program Plan and Funding Request for Fiscal Year 2013-14."

${ }^{87}$ NREL (National Renewable Energy Laboratory), Solar Prospector.

${ }^{88}$ Rackham Technologies, "Case \#01 - Deploying an Icarus Heat System in the Food Industry: Chagnon Dairy, Waterloo, Quebec"; Rackham Technologies, "Case \#02 - The Sun Shines over Quebec: The Case of the Pulp and Paper Industrial Complex in Kingsey Falls."

${ }^{89}$ Lopez et al., "U.S. Renewable Energy Technical Potentials: A GIS-Based Analysis."

${ }^{90}$ Walter Short et al., "Regional Energy Deployment System (ReEDs)."

${ }^{91}$ Lopez et al., "U.S. Renewable Energy Technical Potentials: A GIS-Based Analysis."

92 Ruby, "Industrial Process Steam Generation Using Parabolic Trough Solar Collection."

${ }^{93}$ CSP-F, "Solar Cooling Gorla Maggiore with Fresnel Mirrors."

${ }^{94}$ Lauterbach et al., "The Potential of Solar Heat for Industrial Processes in Germany."

${ }^{95}$ Lopez et al., "U.S. Renewable Energy Technical Potentials: A GIS-Based Analysis."

96 Ibid.

97 Turchi, "Parabolic Trough Reference Plant for Cost Modelling with the Solar Advisor Model (SAM)."

${ }^{98}$ Mason and Reitze, "Establishing Bankability for High Performance, Cost Reducing SkyTrough Parabolic Trough Solar Collector.'

${ }^{99}$ Turchi, "Parabolic Trough Reference Plant for Cost Modelling with the Solar Advisor Model (SAM)."

${ }^{100}$ DSIRE, "Summary Maps - Solar Thermal Process Heat."

101 Ibid.

${ }^{102}$ Center for Sustainable Energy et al., "California Solar Initiative - Thermal: Program Handbook."

${ }^{103}$ SHIP Plants, AEE Intec, "Solar Thermal Plants Database."

${ }^{104}$ Ruby, "Industrial Process Steam Generation Using Parabolic Trough Solar Collection”; Walker et al., "Design and Analysis of a Large Solar Industrial Heat Plant for Frito Lay in Modesto California."

${ }^{105}$ Ruby, "Industrial Process Steam Generation Using Parabolic Trough Solar Collection."

106 Ibid.

107 Ibid.

${ }^{108}$ Walker et al., "Design and Analysis of a Large Solar Industrial Heat Plant for Frito Lay in Modesto California."

${ }^{109}$ Ruby, "Industrial Process Steam Generation Using Parabolic Trough Solar Collection."

${ }^{110}$ NREL (National Renewable Energy Laboratory), Solar Prospector; Ruby, "Industrial Process Steam Generation Using Parabolic Trough Solar Collection."

${ }^{111}$ Ruby, "Industrial Process Steam Generation Using Parabolic Trough Solar Collection."

112 Ibid.

${ }^{113}$ EIA (U.S. Energy Information Administration), "Natural Gas Prices."

${ }^{114}$ Ruby, "Industrial Process Steam Generation Using Parabolic Trough Solar Collection."

115 Miskus, "U.S. Drought Monitor - June 9, 2015."

${ }^{116}$ United States Drought Monitor, "U.S. Drought Monitor - West."

${ }^{117}$ United States Drought Monitor, "U.S. Drought Monitor - California."

${ }^{118}$ Charley Cameron, "San Diego Is Building a Massive \$1 Billion Desalination Plant to Fight Severe Drought."

119 Stuber, "Solar Thermal Desalination of Agricultural Drainage for Reuse: Optimal Design and Case Study." 
${ }^{120}$ Al-Karaghouli and Kazmerski, "Energy Consumption and Water Production Cost of Conventional and Renewable-Energy-Powered Desalination Processes."

${ }^{121}$ Ghaffour et al., "Renewable Energy-Driven Desalination Technologies."

${ }^{122}$ Ibid.; Sharon and Reddy, "A Review of Solar Energy Driven Desalination Technologies"; Reif and Alhalabi, "Solar-Thermal Powered Desalination"; Al-Karaghouli and Kazmerski, "Energy Consumption and Water Production Cost of Conventional and Renewable-Energy-Powered Desalination Processes."

${ }^{123}$ Trieb et al., "Combined Solar Power and Desalination Plants: Techno-Economic Potential in Mediterranean Partner Countries."

${ }^{124}$ Ghaffour et al., "Renewable Energy-Driven Desalination Technologies."

${ }^{125}$ Ziolkowska, "Is Desalination Affordable?"

${ }^{126}$ Walton, "Price of Water 2015: Up 6 Percent in 30 Major U.S. Cities; 41 Percent Rise Since 2010."

127 Ghaffour et al., "Renewable Energy-Driven Desalination Technologies."

${ }^{128}$ Sharon and Reddy, "A Review of Solar Energy Driven Desalination Technologies."

129 Al-Karaghouli and Kazmerski, "Energy Consumption and Water Production Cost of Conventional and Renewable-Energy-Powered Desalination Processes."

${ }^{130}$ Hassabou, Spinnler, and Polifke, "Tecnoeconomic Analysis of Medium and Large-Sacle Desalination Plants Driven by Concentrated Solar Systems in the Mena Region"; Trieb and Müller-Steinhagen, "Concentrating Solar Power for Seawater Desalination in the Middle East and North Africa"; Iaquaniello et al., "Concentrating Solar Power (CSP) System Integrated with MED-RO Hybrid Desalination"; Palenzuela, Alarcón-Padilla, and Zaragoza, "Large-Scale Solar Desalination by Combination with CSP."

${ }^{131}$ Iaquaniello et al., "Concentrating Solar Power (CSP) System Integrated with MED-RO Hybrid Desalination."

132 Trieb et al., "Combined Solar Power and Desalination Plants: Techno-Economic Potential in Mediterranean Partner Countries."

${ }^{133}$ DOE (U.S. Department of Energy), "2015 GTO Peer Review."

${ }^{134}$ Camacho et al., "Advances in Membrane Distillation for Water Desalination and Purification Applications."

${ }^{135}$ Ziolkowska, "Is Desalination Affordable?"

${ }^{136}$ Palenzuela, Alarcón-Padilla, and Zaragoza, "Large-Scale Solar Desalination by Combination with CSP."

137 Al-Karaghouli and Kazmerski, "Energy Consumption and Water Production Cost of Conventional and Renewable-Energy-Powered Desalination Processes."

${ }^{138}$ Stuber et al., "Pilot Demonstration of Concentrated Solar-Powered Desalination of Subsurface Agricultural Drainage Water and Other Brackish Groundwater Sources."

${ }^{139}$ WaterFx, "Product - Aqua4."

${ }^{140}$ Ibid.

${ }^{141}$ Ziolkowska, "Is Desalination Affordable?"

${ }^{142}$ DESWARE Encyclopedia of Desalination and Water Resources, "Energy Requirements of Desalination Processes."

${ }^{143}$ Fagan, "California Drought: Solar Desalination Plant Shows Promise."

${ }^{144}$ SkyFuel Inc., "SkyTrough Thermal Efficiency."

${ }^{145}$ Keller, "Valley Projects Look to the Sun for Clean Water."

${ }^{146}$ Lauterbach et al., "The Potential of Solar Heat for Industrial Processes in Germany."

147 Ibid.

148 Ibid. 


\section{Bibliography}

Al-Karaghouli, Ali, and Lawrence L. Kazmerski. "Energy Consumption and Water Production Cost of Conventional and Renewable-Energy-Powered Desalination Processes."

Renewable and Sustainable Energy Reviews 24 (August 2013): 343-56. doi:10.1016/j.rser.2012.12.064.

Alvarez, Johannes, and Sungyun Han. "Current Overview of Cyclic Steam Injection Process," July 2013.

Beath, Andrew C. "Industrial Energy Usage in Australia and the Potential for Implementation of Solar Thermal Heat and Power." Energy, 2nd International Meeting on Cleaner Combustion (CM0901-Detailed Chemical Models for Cleaner Combustion), 43, no. 1 (July 2012): 261-72. doi:10.1016/j.energy.2012.04.031.

Brightsource Energy. "Coalinga: Project Facts.” Oakland, California: Brightsource Energy, March 30, 2015.

http://www.brightsourceenergy.com/stuff/contentmgr/files/0/ad5d33a2bc493a5079b5dda 609724238/folder/bse_coalinga_fact_sheet_033015.pdf.

Brunner, Christoph. "Solar Heat for Industrial Production Processes: Latest Research and Large Scale Installations." October 15, 2014. http://task49.ieashc.org/data/sites/1/publications/SHC-2014--Brunner--Solar-Heat-for-IndustrialProcesses.pdf.

Calderoni, Marco, Marcello Aprile, Salvatore Moretta, Aristotelis Aidonis, and Mario Motta. "Solar Thermal Plants for Industrial Process Heat in Tunisia: Economic Feasibility Analysis and Ideas for a New Policy." Energy Procedia, 1st International Conference on Solar Heating and Coolingfor Buildings and Industry (SHC 2012), 30 (2012): 13901400. doi:10.1016/j.egypro.2012.11.153.

Camacho, Lucy Mar, Ludovic Dumée, Jianhua Zhang, Jun-de Li, Mikel Duke, Juan Gomez, and Stephen Gray. "Advances in Membrane Distillation for Water Desalination and Purification Applications." Water 5, no. 1 (January 25, 2013): 94-196. doi:10.3390/w5010094.

Cameron, Charley. "San Diego Is Building a Massive \$1 Billion Desalination Plant to Fight Severe Drought." Inhabit.com, May 13, 2015. http://inhabitat.com/san-diego-county-isbuilding-a-massive-1-billion-desalination-plant-to-address-drought/.

Carwile, Clifton, and Russell Hewett. "Barriers to Solar Process Heat Projects: Fifteen Highly Promising (but Cancelled) Projects." Golden, Colorado: National Renewable Energy Laboratory, 1994.

Capital Surini Group International, Inc. and Energetics, Incorporated. "Roadmap for Process Heating Technology: Priority Research \& Development Goals and Near-Term NonResearch Goals To Improve Industrial Process Heating.” Washington, D.C.: U.S. Department of Energy Office of Energy Efficiency and Renewable Energy, March 16, 2001.

https://www1.eere.energy.gov/manufacturing/tech_assistance/pdfs/process_heating_0401 .pdf.

Center for Sustainable Energy, Southern California Edison, Pacific Gas and Electric Company, and Southern California Gas Company. "California Solar Initiative - Thermal: Program Handbook." San Francisco: California Public Utilities Commission, February 2015. http://www.gosolarcalifornia.ca.gov/documents/CSI-Thermal_Handbook.pdf. 
Chan, Julia. "South America's first solar thermal plant comes online." PV Tech, January 3, 2013. http://www.pv-tech.org/news/south_americas_first_solar_thermal_plant_comes_online.

CSP-F. "Ribbon-Cutting for the First Italian CSP Fresnel Plant in the Agrobusiness." CSP-F

Solar, May 20, 2015. http://www.cspfsolar.com/blog/ribbon-cutting-for-the-first-italiancsp-fresnel-plant-in-the-agrobusiness/.

—. "Solar Cooling Gorla Maggiore with Fresnel Mirrors." CSP-F Solar, November 7, 2014. http://www.cspfsolar.com/blog/news/solar-cooling-gorla-maggiore-fresnelmirrors/.

DESWARE: Encyclopedia of Desalination and Water Resources. "Energy Requirements of Desalination Processes." DESWARE, 2015. http://www.desware.net/.

DOE (U.S. Department of Energy). “2015 GTO Peer Review.” Energy.gov, 2015. http://energy.gov/eere/geothermal/events/2015-gto-peer-review.

DSIRE. "Summary Maps - Solar Thermal Process Heat," 2015. http://programs.dsireusa.org/system/program/maps.

EERE (U.S. Department of Energy Office of Energy Efficiency and Renewable Energy). "Sankey Diagram of Process Energy Flow in U.S. Manufacturing Sector." Energy.gov, 2015. http://www.energy.gov/eere/amo/sankey-diagram-process-energy-flow-usmanufacturing-sector.

EIA (U.S. Energy Information Administration). "2010 MECS Survey Data - Table 5.3, End Use of Fuel Consumption.” EIA, March 2013. http://www.eia.gov/consumption/manufacturing/data/2010/. . "2010 MECS Survey Data - Table 5.4, End Use of Fuel Consumption." EIA, March 2013. http://www.eia.gov/consumption/manufacturing/data/2010/. . “Annual Energy Review 2011, Table 2.3.” Washington, D.C.: Energy Information Administration, September 2012. http://www.eia.gov/totalenergy/data/annual/showtext.cfm?t=ptb0203. . "Natural Gas Prices.” EIA, May 29, 2015. http://www.eia.gov/dnav/ng/ng_pri_sum_dcu_SCA_a.htm.

_. "State Energy Data 2013: Updates by Energy Source, Table F19: Natural Gas Consumption Estimates, 2013." Washington, D.C.: Energy Information Administration, March 20, 2015.http://www.eia.gov/state/seds/sep_fuel/html/pdf/fuel_use_ng.pdf.

EPA (Environmental Protection Agency). "Renewable Heating and Cooling - RHC Technologies and Applications," May 8, 2015. http://www2.epa.gov/rhc/rhc-technologies-andapplications.

_. "Renewable Industrial Process Heat," May 8, 2015. http://www2.epa.gov/rhc/renewable-industrial-process-heat.

eSolar Inc. "EOR - Enhanced Oil Recovery." eSolar.com, 2013. http://www.esolar.com/applications/eor/.

Fagan, Kevin. "California Drought: Solar Desalination Plant Shows Promise." San Francisco Chronicle, March 18, 2014. http://www.sfgate.com/science/article/California-droughtSolar-desalination-plant-5326024.php\#photo-6028210.

Fox, Don B., Daniel Sutter, and Jefferson W. Tester. "The Thermal Spectrum of LowTemperature Energy Use in the United States." Energy \& Environmental Science 4, no. 10 (September 27, 2011): 3731-40. doi:10.1039/C1EE01722E. 
Friedmann, Rafael, Fred Coito, Ernst Worrell, Lynn Price, and Eric Masanet. "California Industrial Energy Efficiency Potential." Washington, D.C.: American Council for an Energy-Efficient Economy, 2005. http://aceee.org/files/proceedings/2005/data/papers/SS05_Panel06_Paper07.pdf.

Ghaffour, Noreddine, Jochen Bundschuh, Hacene Mahmoudi, and Mattheus F. A. Goosen. "Renewable Energy-Driven Desalination Technologies: A Comprehensive Review on Challenges and Potential Applications of Integrated Systems." Desalination 356 (January 15, 2015): 94-114. doi:10.1016/j.desal.2014.10.024.

GlassPoint Solar Inc. "GlassPoint PDO Fact Sheet." Fact Sheet. Fremont, California: GlassPoint Solar Inc., 2013. http:/www.glasspoint.com/media/2013/05/GlassPoint-PDO-Fact-SheetFINAL.pdf. . "Use Less Gas For EOR.”www.glasspoint.com, 2015. http://www.glasspoint.com/technology/use-less-gas/. . "Sealed From Dust." www.glasspoint.com, 2015. http://www.glasspoint.com/technology/sealed-from-dust/.

Gregory, Mark, and David Omom. "Solar Enhanced Oil Recovery: An in-Country Value Assessment for Oman.” London: Ernest \& Young LLP, January 2014. http://www.ey.com/Publication/vwLUAssets/EY-Solar-enhanced-oil-recovery-in-OmanJanuary-2014/\$FILE/EY-Solar-enhanced-oil-recovery-in-Oman-January-2014.pdf.

Hassabou, Abdel Hakim, Markus Spinnler, and Wolfgang Polifke. "Tecnoeconomic Analysis of Medium and Large-Sacle Desalination Plants Driven by Concentrated Solar Systems in the Mena Region.” Energy Procedia 42 (2013): 735-44. doi:10.1016/j.egypro.2013.11.076.

Helman, Christopher. "Ironic Or Economic? Oil Giant To Build World's Largest Solar Project." Forbes, July 8, 2015. http://www.forbes.com/sites/christopherhelman/2015/07/08/oilgiant-to-build-worlds-largest-solar-project/.

Hennecke, Klaus. "Solar Process Heat and Co-Generation - A Review of Recent Developments." presented at the SolarPACES, Beijing, China, September 2014.

http:/elib.dlr.de/92330/1/SolarPACES2014Plenary_Hennecke_ProcessHeat_Cogeneratio n.pdf.

Iaquaniello, G., A. Salladini, A. Mari, A. A. Mabrouk, and H. E. S. Fath. "Concentrating Solar Power (CSP) System Integrated with MED-RO Hybrid Desalination.” Desalination 336 (March 3, 2014): 121-28. doi:10.1016/j.desal.2013.12.030.

IEA (International Energy Agency). “Technology Roadmap: Solar Heating and Cooling Foldout.” Paris: International Energy Agency, July 2012. https://www.iea.org/publications/freepublications/publication/IEA_Solar_HC_Roadmap_ FoldOut_Print.pdf.

IEA-ETSAP, and IRENA. "Solar Heat for Industrial Processes: Technology Brief." Paris and Abu Dhabi: International Energy Agency and International Renewabe Energy Agency, January 2015. http://www.solarthermalworld.org/sites/gstec/files/news/file/2015-0227/irena-solar-heat-for-industrial-processes_2015.pdf.

International Energy Agency Solar Heating and Cooling Programme. "Programme Description," 2015. http://www.iea-shc.org/programme-description.

Keller, Ben. "Valley Projects Look to the Sun for Clean Water." The Business Journal, July 21, 2014. http://www.thebusinessjournal.com/news/technology/13064-valley-projects-looksto-the-sun-for-clean-water. 
Lauterbach, C., B. Schmitt, U. Jordan, and K. Vajen. "The Potential of Solar Heat for Industrial Processes in Germany." Renewable and Sustainable Energy Reviews 16, no. 7 (September 2012): 5121-30. doi:10.1016/j.rser.2012.04.032.

Lopez, Anthony, Billy Roberts, Donna Heimiller, Nate Blair, and Gian Porro. "U.S. Renewable Energy Technical Potentials: A GIS-Based Analysis.” Golden, Colorado: National Renewable Energy Laboratory, July 2012. http://www.nrel.gov/docs/fy12osti/51946.pdf.

Mason, A., and E. Reitze. "Establishing Bankability for High Performance, Cost Reducing SkyTrough Parabolic Trough Solar Collector.” Energy Procedia 49 (2014): 155-62. doi:10.1016/j.egypro.2014.03.017.

Miskus, David. "U.S. Drought Monitor - June 9, 2015.” National Drought Mitigation Center, June 11, 2015. http://droughtmonitor.unl.edu/data/pdfs/20150609/20150609_usdm.pdf.

NREL (National Renewable Energy Laboratory). Solar Prospector. National Renewable Energy Laboratory, 2012. http://maps.nrel.gov/prospector.

Palenzuela, Patricia, Diego-César Alarcón-Padilla, and Guillermo Zaragoza. "Large-Scale Solar Desalination by Combination with CSP: Techno-Economic Analysis of Different Options for the Mediterranean Sea and the Arabian Gulf." Desalination 366 (June 15, 2015): 130-38. doi:10.1016/j.desal.2014.12.037.

Petros Group. “EOR Classification.” Petros Group, 2015. http://petros.ru/eng/worldmarketoil/?action=show\&id=287\#3.1.

Rackham Technologies. "Case \#01 - Deploying an Icarus Heat System in the Food Industry: Chagnon Dairy, Waterloo, Quebec.” Rackham, 2014. http://rackam.com/fr/studies/chagnon/.

Rackham Technologies. "Case \#02 - The Sun Shines over Quebec: The Case of the Pulp and Paper Industrial Complex in Kingsey Falls.” Rackham, 2014. http://www.rackam.com/en/studies/cascades/.

Ramos, C., R. Ramirez, and J. Beltran. "Potential Assessment in Mexico for Solar Process Heat Applications in Food and Textile Industries." Energy Procedia, Proceedings of the SolarPACES 2013 International Conference, 49 (2014): 1879-84. doi:10.1016/j.egypro.2014.03.199.

Reif, John H., and Wadee Alhalabi. "Solar-Thermal Powered Desalination: Its Significant Challenges and Potential." Renewable and Sustainable Energy Reviews 48 (August 2015): 152-65. doi:10.1016/j.rser.2015.03.065.

Ruby, Steve. "Industrial Process Steam Generation Using Parabolic Trough Solar Collection." Denver: American Energy Assets, November 2010. http://www.energy.ca.gov/2011publications/CEC-500-2011-040/CEC-500-2011-040.pdf.

Sargent, Stephen L., Barbara H. Glenn, and David W. Kearney. "Solar industrial process heat." Environmental Science and Technology 14:5 (May 1980): 518-522. doi:10.1021/es60165a605.

Schrupp, Linda. "The Natural Gas Research, Development, and Demonstration Program: Proposed Program Plan and Funding Request for Fiscal Year 2013-14." Sacramento: California Energy Commission, March 2013. http://www.energy.ca.gov/2013publications/CEC-500-2013-014/CEC-500-2013-014.pdf. Schweiger, Hans, Joao Farinha Mendes, Nikolaus Benz, Klaus Hennecke, Germán Prieto, Mercé Cusí, and Helder Gonçalves. "The Potential of Solar Heat in Industrial Processes: A State of the Art Review for Spain and Portugal." Barcelona: AIGUASOL Enginyería, January 2011. 
Sharon, H., and K. S. Reddy. "A Review of Solar Energy Driven Desalination Technologies." Renewable and Sustainable Energy Reviews 41 (January 2015): 1080-1118. doi:10.1016/j.rser.2014.09.002.

Shehabi, Arman, William Morrow, and Eric Masanet. "United States Industrial Sector Energy End Use Analysis.” Berkeley, California: Lawrence Berkeley National Laboratory, no date. https://ies.lbl.gov/sites/all/files/lbnl-5993e_1.pdf.

SHIP Plants, AEE Intec. "Cremo SA,” 2015. http://ship-plants.info/projects/149. . "Solar Thermal Plants Database," 2015. http://ship-plants.info/solar-thermalplants? country $=$ United + States\&page $=1$.

Short, Walter, Patrick Sullivan, Trieu Mai, Matthew Mowers, Caroline Uriarte, Nate Blair, Donna Heimiller, and Andrew Martinez. "Regional Energy Deployment System (ReEDs).” Golden, Colorado: National Renewable Energy Laboratory, 2011.

SkyFuel Inc. "SkyTrough Thermal Efficiency." Arvada, Colorado: SkyFuel Inc., August 2010. http://www.skyfuel.com/downloads/SkyTroughEfficiency\%28SkyFuel\%29.pdf.

Solarlite CSP Technology GmbH. "CSP Technologies in Practice.” IHK zu Rostock, Germany, July 29, 2014.

http://www.rostock.ihk24.de/linkableblob/hroihk24/international/downloads/3024446/.3./ data/Erfolgreich_mit_gruenen_Technologien_aus_MV_-_Ein_Praxisbericht-data.pdf. . "TSE 1" Kanchanaburi, Thailand." Solarlite CSP Technology GmbH, 2014. http://solarlite-csp.com/en/reference/tse-1-kanchanaburi-provinz-thailand/. . "The Sun Is Shining for You as Well." Solarlite CSP Technology, June 2014. http://solarlite-csp.com/wpcontent/uploads/2014/06/lye_solarlite_faltblatt_casestudies_brauerei_lektoriert.pdf.

SolarPACES. "TASK IV: Solar Heat Integration in Industrial Processes," 2015. http://www.solarpaces.org/tasks/task-iv-solar-heat-integration-in-industrial-processes.

Stuber, Matthew D. "Solar Thermal Desalination of Agricultural Drainage for Reuse: Optimal Design and Case Study," Forthcoming.

Stuber, Matthew D., Christopher Sullivan, Spencer A. Kirk, Jennifer A. Farrand, Philip V. Schillaci, Brian D. Fojtasek, and Aaron H. Mandell. "Pilot Demonstration of Concentrated Solar-Powered Desalination of Subsurface Agricultural Drainage Water and Other Brackish Groundwater Sources.” Desalination 355 (January 1, 2015): 186-96. doi:10.1016/j.desal.2014.10.037.

Trieb, Franz, and Hans Müller-Steinhagen. "Concentrating Solar Power for Seawater Desalination in the Middle East and North Africa." Desalination 220, no. 1-3 (March 1, 2008): 165-83. doi:10.1016/j.desal.2007.01.030.

Trieb, Franz, Massimo Moser, Jürgen Scharfe, Tomasek Marie Luise, Jürgen Kern, Thomas Nieseor, Nicolas Cottret, Pinhas Glueckstem, Inbal David, and Menahem Priel. "Combined Solar Power and Desalination Plants: Techno-Economic Potential in Mediterranean Partner Countries.” Stuttgart, Germany: DLR: Institute for Engineering Thermodynamics, June 2009.

http://www.solarthermalworld.org/sites/gstec/files/Technology\%20Review\%20and\%20S election $\% 20$ of $\% 20$ CSP\%20and\%20Desalination\%20Configurations.pdf.

Tunio, Saleem Qadir, Abdul Haque Tunio, Naveed Ahmed Ghirano, and Ziad Mohamed El Adawy. "Comparison of Different Enhanced Oil Recovery Techniques for Better Oil Productivity." International Journal of Applied Science and Technology 1:5 (2011): 14353. 
Turchi, Craig. "Parabolic Trough Reference Plant for Cost Modelling with the Solar Advisor Model (SAM)." Golden, Colorado: National Renewable Energy Laboratory, July 2010. http://www.nrel.gov/docs/fy10osti/47605.pdf.

United States Drought Monitor. "U.S. Drought Monitor - California,” June 11, 2015. http://droughtmonitor.unl.edu/Home/StateDroughtMonitor.aspx?CA.

—. "U.S. Drought Monitor - West," June 11, 2015. http://droughtmonitor.unl.edu/Home/RegionalDroughtMonitor.aspx?west.

Utilities ME Staff. "German Firm Installs CSP System at Jordan Factory." Utilities-Me.com, May 19, 2015. http://www.utilities-me.com/article-3547-german-firm-installs-cspsystem-at-jordan-factory/.

Walker, Andy, Chuck Kutscher, Al Halvorsen, Chris McKenna, Dave Chambers, and Ken May. "Design and Analysis of a Large Solar Industrial Heat Plant for Frito Lay in Modesto California." In ASME Proceedings, 657-62. Long Beach, California: Midwest Research Institute, 2007. doi:10.1115/ES2007-36050.

Walker, Andy. "Frito-Lay North American/NREL CRADA: Cooperative Research and Development Final Report." Golden, Colorado: National Renewable Energy Laboratory, June 2013. http://www.nrel.gov/docs/fy13osti/58095.pdf.

Walton, Brett. "Price of Water 2015: Up 6 Percent in 30 Major U.S. Cities; 41 Percent Rise Since 2010." Circleofblue.org, April 22, 2015. http://www.circleofblue.org/waternews/2015/world/price-of-water-2015-up-6-percent-in30-major-u-s-cities-41-percent-rise-since-2010/.

WaterFx. "Product - Aqua4," 2015. http://waterfx.co/aqua4/.

XENERGY Inc. "California Industrial Energy Efficiency Market Characterization Study." Prepared for Pacific Gas and Electric Company. Oakland, California: XENERGY Inc., December 2001.

http://www.calmac.org/publications/California\%20Ind\%20EE\%20Mkt\%20Characterizati on.pdf.

Ziolkowska, Jadwiga R. "Is Desalination Affordable?—Regional Cost and Price Analysis." Water Resources Management 29, no. 5 (December 18, 2014): 1385-97. doi:10.1007/s11269-014-0901-y. 